Environmental Security Technology Certification Program

\title{
Passive Reactive Berm to Provide Low Maintenance Lead Containment at Active Small Arms Firing Ranges
}

Field Demonstration

Michelle Wynter, Steven L. Larson, W.A. Martin,

Chris S. Griggs, Gregory O'Connor, David Mackie, and Catherine C. Nestler

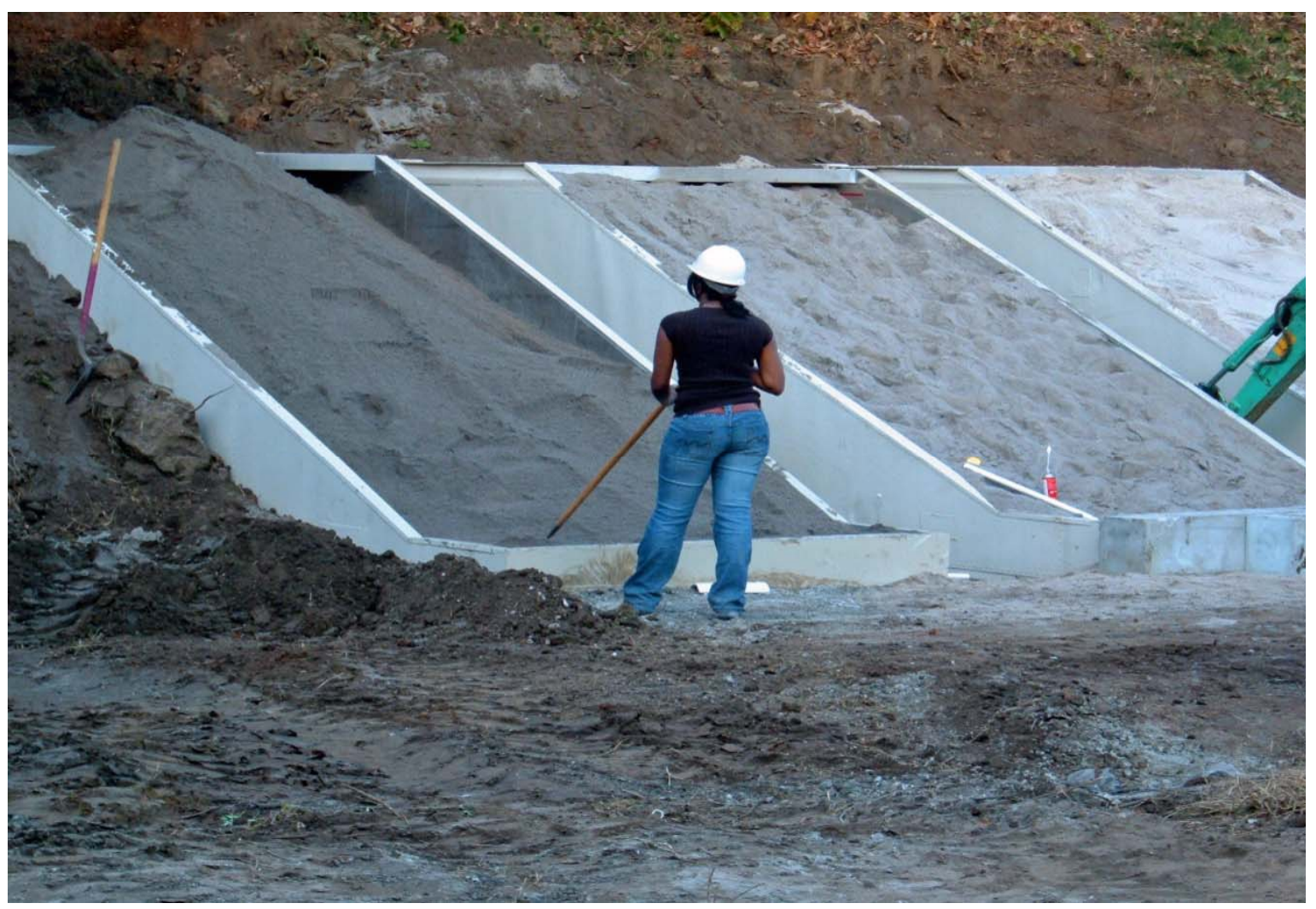




\section{Passive Reactive Berm to Provide Low Maintenance Lead Containment at Active Small Arms Firing Ranges}

Field Demonstration

Michelle Wynter, Steven L. Larson, W. Andy Martin, Chris S. Griggs

Environmental Laboratory

U.S. Army Engineer Research and Development Center

3909 Halls Ferry Road

Vicksburg, MS 39180-6199

Gregory O'Connor

U.S. Army RDECOM-ARDEC

Energetics, Warheads, \& Environmental Technology Research Division

Building 355

Picatinny, NJ 07806-5000

David Mackie

AMEC Earth and Environmental, Inc.

285 Davidson Avenue, Suite 100

Somerset, NJ 08873

Catherine C. Nestler

Applied Research Associates

119 Monument Place

Vicksburg, MS 39180

Final report

Approved for public release; distribution is unlimited

\footnotetext{
Prepared for U.S. Army Corps of Engineers

Washington, DC 20314-1000

Under Work Unit 33143

Monitored by U.S. Army Engineer Research and Development Center 3909 Halls Ferry Road, Vicksburg, MS 39180-6199
} 


\section{Abstract}

Heavy metals are released into the environment as a result of critical military live-fire training. Preventing heavy-metal migration into and contamination of the local environment is crucial because remediating contaminated soils is resource intensive, difficult, and costly. Previous studies have demonstrated that phosphate amendments have been successfully used as a best management practice (BMP) to immobilize metal contaminants. The Passive Reactive Berm $\left(\mathrm{PRBerm}^{\mathrm{TM}}\right.$ ) technology incorporates phosphate amendments with ballistic sand to immobilize soluble metals (e.g., lead) during the inevitable bullet corrosion process. Treatability studies determined that an amendment ratio of 5\% (weight/ weight) to sand was sufficient to contain $>90 \%$ of soluble lead within the berm material. The technology was field tested on the M-60 small arms firing range (SAFR) at Charleston Air Force Base (CAFB) in Charleston, South Carolina. The CAFB PRBerm ${ }^{\mathrm{TM}}$ was tested with a 5\% TRAPPS $^{\mathrm{TM}}$ amendment (a granular, apatite-based material), alone and in combination with a $5 \%$ thermally treated fish bone Apatite $^{\mathrm{TM}}$.

For the CAFB PRBerm ${ }^{\mathrm{TM}}$, storm water runoff and leachate water samples were collected directly from the SAFR and analyzed for metals, total suspended solids (TSS), and $\mathrm{pH}$. Reduced metals migration in soil leachate and surface water runoff when compared to the traditional earthen berm was observed. The total suspended solids in the leachate and runoff waters from the amended berms increased over the control berm. Results indicated that the $\mathrm{pH}$ of the runoff waters from the amended berms remained acidic.

The benefits of the PRBerm ${ }^{\mathrm{TM}}$ when compared to the traditional earthen berm, or a fully contained bullet trap, include reduced metals migration in soil leachate and surface water runoff, as well as reduced construction and operation costs. The PRBerm ${ }^{\mathrm{TM}}$ has the potential to provide a useful, lowcost tool for defense forces to maintain active firing ranges while managing the inevitable effects of small arms residue corrosion in a low-cost and effective manner.

DISCLAIMER: The contents of this report are not to be used for advertising, publication, or promotional purposes. Citation of trade names does not constitute an official endorsement or approval of the use of such commercial products. All product names and trademarks cited are the property of their respective owners. The findings of this report are not to be construed as an official Department of the Army position unless so designated by other authorized documents. 


\section{Contents}

Abstract...................................................................................................................................... if

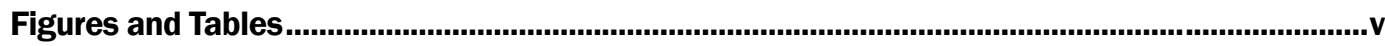

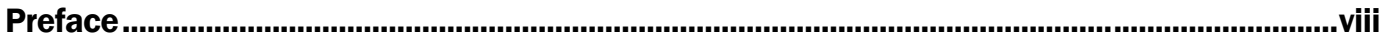

Unit Conversion Factors........................................................................................................

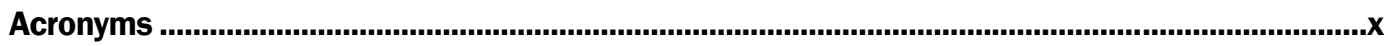

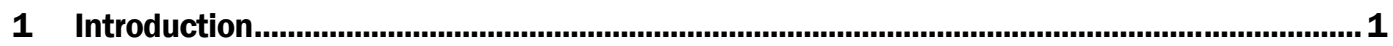

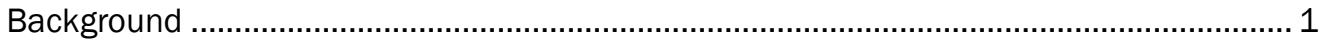

Impact Berm Deceleration Media ............................................................................... 3

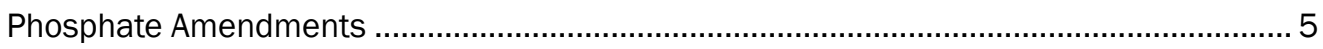

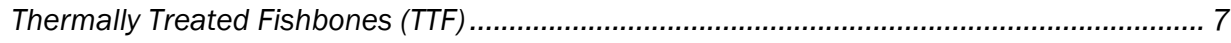

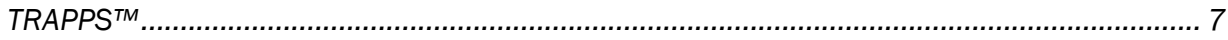

Metal Oxide Amendments........................................................................................... 7

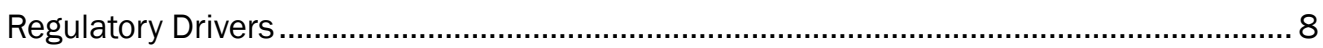

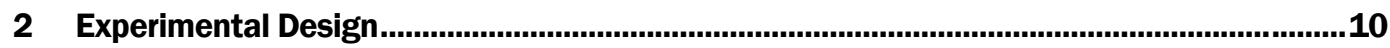

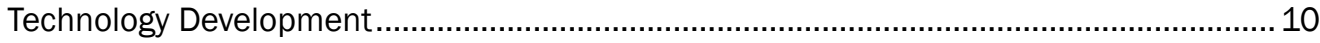

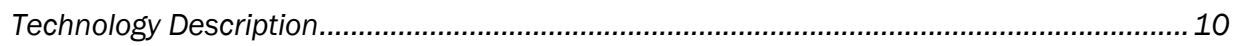

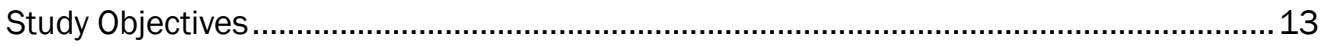

3 Materials and Methods..................................................................................................14

Charleston Air Force Base (CAFB) M-60 Range .......................................................... 14

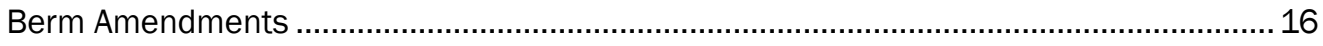

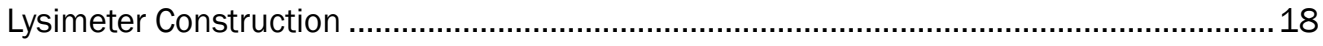

Lysimeter Assembly at the CAFB Range..................................................................20

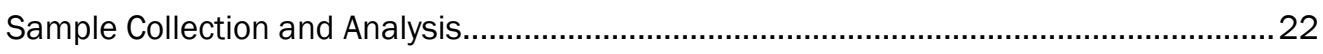

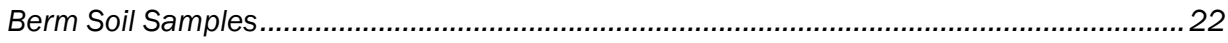

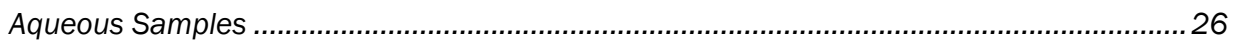

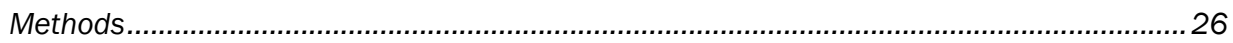

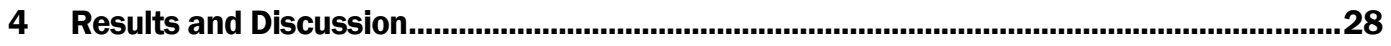

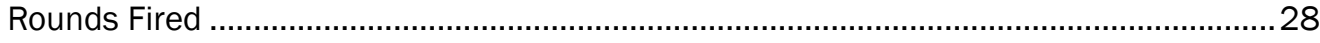

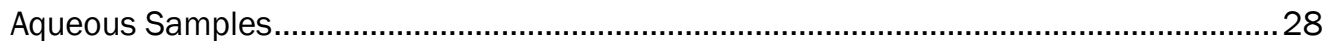

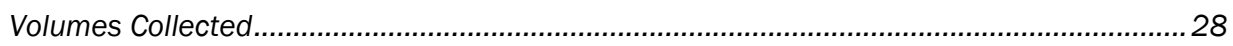

$\mathrm{pH}$

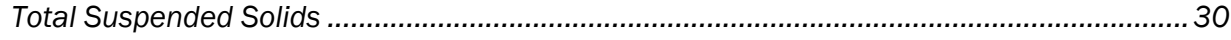

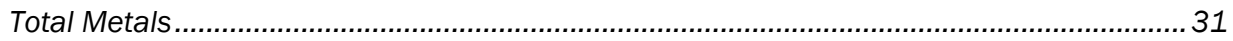

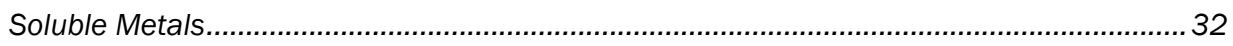

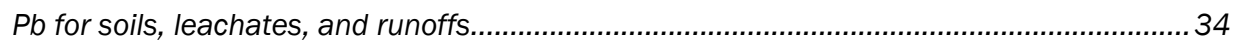

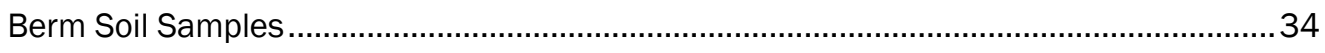


$\mathrm{pH}$

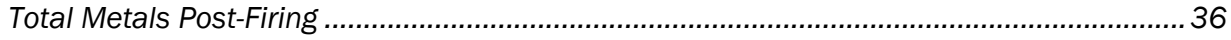

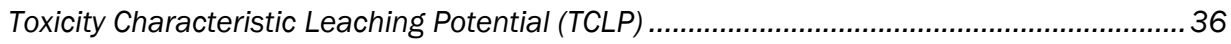

DDI Suspend and Settle Leaching Procedure (DDI S\&S)...................................................... 38

Synthetic Precipitation Leaching Procedure (SPLP)............................................................. 42

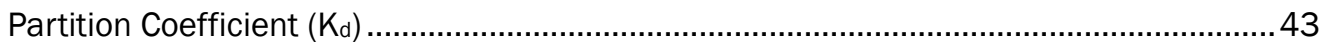

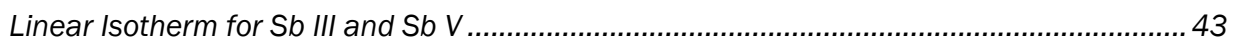

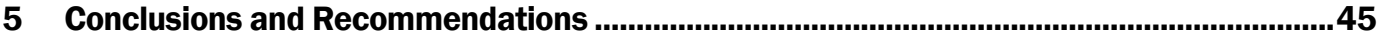

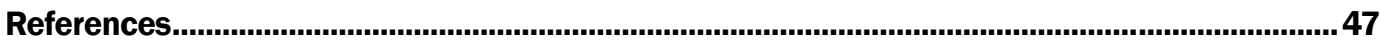

Appendix A: Field Data ...............................................................................................................52

Report Documentation Page 


\section{Figures and Tables}

\section{Figures}

Figure 1. Potential compliance isues on small arms firing ranges................................................... 2

Figure 2. Effect of PRBerm ${ }^{\mathrm{TM}}$ technology on regulatory compliance issues....................................... 3

Figure 3. Schematic cross xection of Charleston AFB PRBerm ${ }^{\text {TM }}$ technology application. ................ 11

Figure 4. Pre-construction view of the three firing points and impact berm area at the CAFB range. View is through the individual firing positions towards the impact berm.

Figure 5. Pre-construction close up view through the pipe that forms the firing line and looking towards the berm.

Figure 6. Location of Charleston AFB, SC.

Figure 7. Aerial view of the Charleston Air Force Base with the location of the M-60 range indicated within the red box

Figure 8. Aerial view of the $\mathrm{M}-60$ range at Charleston AFB indicating possible bullet firing distances.

Figure 9. Aerial view of the M-60 range at the CAFB indicating the potential decrease of the ricochet hazard area by construction of a new eyebrow on the firing platform (AMEC).

Figure 10. Completed field lysimeter prior to transport to the CAFB range.

Figure 11. Interior view of the completed lysimeter demonstrating the ridged bottom to facilitate flow of the leachate from the amended ballistic sand

Figure 12. Interior view of the completed field lysimeter demonstrating the leachate collection system.

Figure 13. Assembly diagram of the left lysimeter showing arrangement of the leachate and runoff water collection systems.

Figure 14. Assembly diagram of the center lysimeter showing arrangement of the leachate and runoff water collection systems.

Figure 15. Assembly diagram of the right lysimeter showing arrangement of the leachate and runoff water collection systems.

Figure 16. Removal of the old impact berm composed of local soil from under the newly constructed protective eyebrow.

Figure 17. Placement of the three lysimeters in the impact berm in line with the three fixed firing positions.

Figure 18. Placement of the amended ballistic sand in the lysimeters.

Figure 19. The completed impact berm enclosing the three experimental treatment lysimeters on the range, CAFB.

Figure 20. $\mathrm{pH}$ of lysimeter leachate and runoff water collected during the PRBerm ${ }^{\mathrm{TM}}$ field demonstration at the CAFB M60 range.

\section{Tables}

Table 1. Soil chemistry that promotes transport of $\mathrm{Pb}$ off-range in surface water and to groundwater via leachate. 
Table 2. Amendment composition in the three field demonstration lysimeters..............................20

Table 3. Summary of analysis methods and frequency. .............................................................. 27

Table 4. Type and number of rounds fired into each lysimeter on the CAFB range during

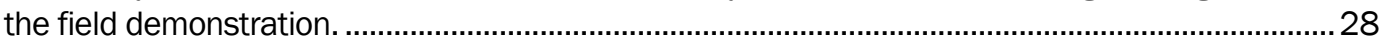

Table 5. Volume of effluent collected from the PRBerm ${ }^{\text {TM }}$ lysimeters during the field demonstration 29

Table 6. Soil pH from control and experimental lysimeters pre- and post firing $(n=3) \ldots \ldots \ldots \ldots \ldots \ldots . . . .30$

Table 7. Comparison of total suspended solids concentrations in leachate and runoff water collected during the PRBerm ${ }^{\mathrm{TM}}$ demonstration at the CAFB range. 31

Table 8. Average concentration of total (digested) metals in lysimeter leachate $(\mathrm{mg} / \mathrm{L}, \mathrm{n}=3)$............. 31

Table 9. Average concentration of total (digested) metals in lysimeter runoff water $(\mathrm{mg} / \mathrm{L}, \mathrm{n}=3)$. 32

Table 10. Average concentration of soluble metals in lysimeter leachate $(\mathrm{mg} / \mathrm{L}, \mathrm{n}=3) \ldots \ldots \ldots \ldots \ldots \ldots . . .33$

Table 11. Average concentration of soluble metals in lysimeter runoff water $(\mathrm{mg} / \mathrm{L}, \mathrm{n}=3) \ldots \ldots \ldots \ldots . . .33$

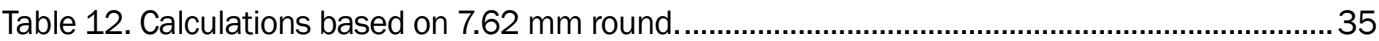

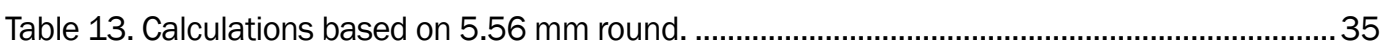

Table 14. Total concentration in soil for both rounds....................................................................35

Table 15. Calculated $\mathrm{Pb}$ concentration in lysimeters.......................................................................36

Table 16. Comparison of pre- and post-demonstration soil $\mathrm{pH}$ from the PRBerm ${ }^{\mathrm{TM}}$ lysimeters $(n=3)$

Table 17. Average concentration of total (digested) metals in bulk lysimeter soil post-firing

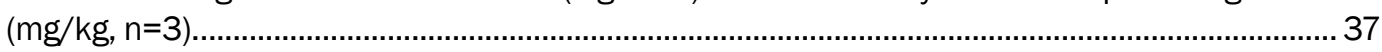

Table 18. Average TCLP metal concentration of post-firing bulk lysimeter soils $(\mathrm{mg} / \mathrm{Kg}, \mathrm{n}=3) \ldots \ldots \ldots . . .37$

Table 19. Average TCLP Pb, Total Pb and the Pb leachability ratios (TCLP to total $\mathrm{Pb}$ )) in

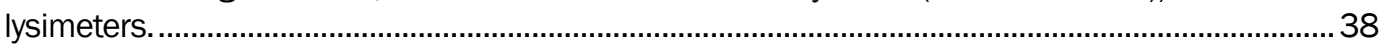

Table 20. Comparison of average TCLP metal concentrations from pre-firing and postfiring soil $(\mathrm{mg} / \mathrm{L}, \mathrm{n}=3)$.

Table 21. Average post-firing TCLP metal concentrations in lysimeters at different dimensions ( $\mathrm{mg} / \mathrm{L}, \mathrm{n}=3$ )

Table 22. Average metal concentrations ( $\mathrm{mg} / \mathrm{L}$ ) for bulk lysimeter soil samples post-DDI suspend and settle $(n=3)$.

Table 23. Comparison of average DDI S\&S metal concentrations from pre-firing and post-firing soil ( $\mathrm{mg} / \mathrm{L}, \mathrm{n}=3$ ).

Table 24. Average post-firing DDI S\&S metal concentrations in lysimeters at different dimensions ( $\mathrm{mg} / \mathrm{L}, \mathrm{n}=3$ ).

Table 25. Comparison of average SPLP metal concentrations from pre-firing and postfiring soil $(\mathrm{mg} / \mathrm{L}, \mathrm{n}=3)$.

Table 26. Average metal concentrations (mg/L) for bulk lysimeter soil samples post-SPLP $(n=3)$............ 43

Table 27. Summary of $\mathrm{Sb}(\mathrm{III})$ and $\mathrm{Sb}(\mathrm{V})$ linear $\mathrm{K}_{\mathrm{d}}$ data. ................................................................. 44

Table A1. Volume of leachate and runoff................................................................................52

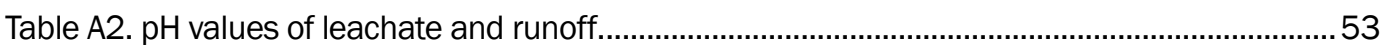

Table A3. Total suspended solids (TSS) values of leachate and runoff (ppm)................................54

Table A4. Digested metal concentration in leachate for control lysimeter (ppm)............................55

Table A5. Digested metal concentration in runoff for control lysimeter (ppm).................................56 
Table A6. Digested metal concentration in leachate for $7.62 \mathrm{~mm}$ lysimeter (ppm). 57

Table A7. Digested metal concentration in runoff for 7.62 mm lysimeter (ppm). ..............................58

Table A8. Digested metal concentration in leachate for 5\% TTF (ppm).........................................59

Table A9. Digested metal concentration in leachate for 5\% TRAPPS $^{\mathrm{TM}}$ (ppm) ................................60

Table A10. Digested metal concentration in runoff for Left TRAPPS ${ }^{\mathrm{TM}}$ (ppm)................................ 61

Table A11. Soluble metal concentration in leachate for control lysimeter (ppm)............................62

Table A12. Soluble metal concentration in runoff for control lysimeter (ppm) . ................................63

Table A13. Soluble metal concentration in leachate for $7.62 \mathrm{~mm}$ lysimeter (ppm). .........................64

Table A14. Soluble metal concentration in runoff for $7.62 \mathrm{~mm}$ lysimeter (ppm)...............................65

Table A15. Soluble metal concentration in leachate for 5\% TTF (ppm)..........................................66

Table A16. Soluble metal concentration in leachate for 5\% TRAPPS $^{\text {TM }}(\mathrm{ppm})$................................67

Table A17. Soluble metal concentration in runoff for Left TRAPPS ${ }^{\mathrm{TM}}(\mathrm{ppm})$....................................68

Table A18. Pre TCLP leaching concentrations for bulk soil samples ( $n=3 ; p p m)$. ............................69

Table A19. Post TCLP leaching Pb, $\mathrm{Cr}, \mathrm{Cu}, \mathrm{Ni}, \mathrm{Zn}$, and Fe concentrations for bulk soil samples $(n=3 ; p p m)$.

Table A2O. Post TCLP leaching Mn, Mo, V, Sb, Ca, and As concentrations for bulk soil samples $(n=3 ; p p m)$ 70

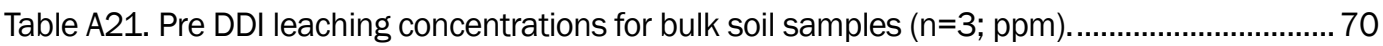

Table A22. Post DDI Suspend and Settle Pb, $\mathrm{Cr}, \mathrm{Cu}, \mathrm{Ni}, \mathrm{Zn}$, and Fe concentrations for bulk soil samples ( $n=3$; ppm).

Table A23. Post DDI Suspend and Settle leaching Mn, Mo, V, Sb, Ca, and As concentrations for bulk soil samples ( $n=3 ; p p m)$.

Table A24. Pre SPLP leaching concentrations for bulk soil samples ( $n=3 ; p p m)$.

Table A25. Post SPLP Pb, $\mathrm{Cr}, \mathrm{Cu}, \mathrm{Ni}, \mathrm{Zn}$, and Fe concentrations for bulk soil samples ( $\mathrm{n}=3 ; \mathrm{ppm})$............. 72

Table A26. Post SPLP Mn, Mo, V, Sb, Ca, and As concentrations for bulk soil samples $(\mathrm{n}=3 ; \mathrm{ppm})$. . .72

Table A27. Digested post soil concentrations $\mathrm{Pb}, \mathrm{Cr}, \mathrm{Cu}, \mathrm{Ni}, \mathrm{Zn}$, and Fe (n=3; ppm)....................... 73

Table A28. Digested post soil concentrations for Mn, Mo, V, Sb, Ca, As, and P ( $\mathrm{n}=3$; ppm)............. 73

Table A29. Post soil digests concentrations for control lysimeter at 0-4L:0-5H...............................73

Table A30. Post soil digests concentrations for control lysimeter at 0-4L:5-10H. ............................74

Table A31. Post soil digests concentrations for control lysimeter at 4-8L:0-5H (ppm)......................75

Table A32. Post soil digests concentrations for control lysimeter at 4-8L:5-10H (ppm)................... 75

Table A33. Post soil digests concentrations for $7.62 \mathrm{~mm}$ lysimeter at 0-4L:0-5H (ppm).................. 76

Table A34. Post soil digests concentrations for $7.62 \mathrm{~mm}$ lysimeter at 0-4L:5-10H (ppm). .............. 77

Table A35. Post soil digests concentrations for 7.62 mm lysimeter at 4-8L:0-5H (ppm).................. 77

Table A36. Post soil digests concentrations for Left 5\% TRAPPS'M lysimeter at 4-8L:5-10H (ppm). ............. 78

Table A37. Post soil digests concentrations for Left 5\% TRAPPS'M lysimeter at 0-4L:0-5H (ppm). ............ 79

Table A38. Post soil digests concentrations for Left 5\% TRAPPS'M lysimeter at 0-4L:5-10H (ppm)............ 79

Table A39. Post soil digests concentrations for Left 5\% TRAPPS'M lysimeter at 4-8L:0-5H (ppm). ................ 80

Table A40. Post soil digests concentrations for Left 5\% TRAPPS ${ }^{\text {TM }}$ lysimeter at 4-8L:5-10H (ppm)............ 81

Table A41 Linear $\mathrm{K}_{\mathrm{d}}$ Data: Triplicate data for each lysimeter for Sb(III).......................................... 81

Table A42. Linear $K_{d}$ Data: Triplicate data for each lysimeter for Sb(V).......................................... 82 


\section{Preface}

This report contains information that was obtained from field demonstration studies conducted at the Charleston Air Force Base (CAFB) M-60 small arms firing ranges (SAFR). Funding was provided by the Environmental Security Technology Certification Program (ESTCP). The project was designated ESTCP project ER-0406. It was an evaluation of the use of sand as a deceleration medium in SAFR berms in conjunction with appropriate amendments designed to retard the migration of lead into the surrounding environment.

Michelle Wynter of the Environmental Engineering Branch (EP-E), Environmental Laboratory (EL), Engineer Research and Development Center (ERDC), Vicksburg, MS, prepared this report. Co-authors of this report include Dr. Steven L. Larson, W. Andy Martin, Chris S. Griggs, all ERDC-EL; Greg O'Connor, U.S. Army RDECOM-ARDEC Energetics, Warheads, \&Environmental Technology Research Division; David Mackie, AMEC Earth and Environment, Somerset, New J ersey; and Cathy C. Nestler, Applied Research and Associates, Inc. (ARA). The authors gratefully acknowledge the technical assistance provided by Milton Beverly, Environmental Research and Development, Inc., (ERAD) and Dr. Catherine Thomas, J ackson State University. A special thanks to the Charleston Air Force Base (CAFB) CAFB Range and Bioenvironmental Engineering personnel for assistance during this project.

This study was conducted under the direct supervision of Dr. Pat Deliman, Technical Director, Environmental Modeling and Assessments, and the general supervision of Warren P. Lorentz, Chief, Environmental Processes and Engineering Division, and of Dr. Elizabeth C. Fleming, Director, EL. At the time of this study, COL Kevin J. Wilson was Commander of the ERDC, and Dr. J effery P. Holland was Director of the ERDC. 


\section{Unit Conversion Factors}

\begin{tabular}{|c|c|c|}
\hline Multiply & By & To Obtain \\
\hline Acres & $4,046.873$ & square meters \\
\hline cubic feet & 0.02831685 & cubic meters \\
\hline cubic inches & 1.6387064 E-05 & cubic meters \\
\hline cubic yards & 0.7645549 & cubic meters \\
\hline degrees Fahrenheit & $(\mathrm{F}-32) / 1.8$ & degrees Celsius \\
\hline Feet & 0.3048 & meters \\
\hline gallons (U.S. liquid) & 3.785412 E-03 & cubic meters \\
\hline Inches & 0.0254 & meters \\
\hline Microns & $1.0 \mathrm{E}-06$ & meters \\
\hline miles (nautical) & 1,852 & meters \\
\hline miles (U.S. statute) & $1,609.347$ & meters \\
\hline miles per hour & 0.44704 & meters per second \\
\hline Mils & 0.0254 & millimeters \\
\hline ounces (mass) & 0.02834952 & kilograms \\
\hline pounds (mass) & 0.45359237 & kilograms \\
\hline square feet & 0.09290304 & square meters \\
\hline square inches & 6.4516 E-04 & square meters \\
\hline square yards & 0.8361274 & square meters \\
\hline tons ( 2,000 pounds, mass) & 907.1847 & kilograms \\
\hline tons $(2,000$ pounds, mass) per square foot & $9,764.856$ & kilograms per square meter \\
\hline Yards & 0.9144 & meters \\
\hline
\end{tabular}




\section{Acronyms}

AFB

AMC

ASTM

ATC

AW

BMP

BOD

CAFB

COTS

DDI S\&S

DOC

DoD

EL

ERDC

ESTCP

ETL

GSL

HQDA

HDPE

ICP-AES

ID

IDL

ISO

ITRC

MCLG

ND

PRBerm $^{\text {TM }}$

SACON

SAFR
Air Force Base

Air Mobile Command

American Society for Testing and Materials

Aberdeen Test Center

Airlift Wing

Best Management Practice

Biological oxygen Demand

Charleston Air Force Base

Commercially available off the shelf

Distilled Deionized Water Suspend and Settle

Dissolved Organic Carbon

Department of Defense

Environmental Laboratory

Engineer Research and Development Center

Environmental Security Technology

Certification Program

Engineering Technical Letter

Geotechnical and Structures Laboratory

Headquarters, Department of the Army

High-density polyethylene

Inductively Coupled Plasma Atomic Emission Spectroscopy

Internal diameter

Instrument detection limit

International Organization for Standarization

Interstate Technology and Regulatory Council

Maximum Contamination Level Goal

Non-detect

Passive Reactive Berm

Shock absorbing concrete

Small arms firing range 
SDZ

SPLP

TCLP

TSS

TTF

w/ w
Safety danger zone

Synthetic Precipitate Leaching Procedure

Toxicity Characteristic Leaching Procedure

Total suspended solids

Thermally-treated fishbones

weight:weight

\section{Chemical names}

$\begin{array}{ll}\mathrm{Ca} & \text { Calcium } \\ \mathrm{Cr} & \text { Chromium } \\ \mathrm{Cu} & \text { Copper } \\ \mathrm{Fe} & \text { Iron } \\ \mathrm{Mn} & \text { Manganese } \\ \mathrm{Mo} & \text { Molybdenum } \\ \mathrm{Ni} & \text { Nickel } \\ \mathrm{P} & \text { Phosphorus } \\ \mathrm{Pb} & \text { Lead } \\ \mathrm{Sb} & \text { Antimony } \\ \mathrm{V} & \text { Vanadium } \\ \mathrm{Zn} & \text { Zinc }\end{array}$




\section{Introduction}

\section{Background}

More than 3,000 active small-arms firing ranges (SAFR) and 9,000 nonmilitary shooting ranges in the USA (Interstate Technology and Regulatory Council (ITRC) 2003) provide training areas for military personnel, law enforcement, and recreational shooters. According to Cao et al. (2003), SAFRs are a significant source of lead (Pb) in the environment around the range. Transport of contaminants in the environment is impacted by such things as soil properties, $\mathrm{pH}$, and weathering of the contaminant. Metals present in SAFR soils can potentially migrate off-site into sensitive environmental receptors (e.g., wetlands, surface-water bodies, groundwater supplies) through surface-water transport (runoff) or by vertical migration (leaching) into the groundwater. Soil type, slope, rainfall intensity, and vegetation influence the release of contaminants by runoff. The resulting environmental contamination could result in state or federal regulatory action, which could ultimately impose constraints on critical military training activities at SAFRs (Figure 1).

The use of earthen backstops (berms) composed of native soil can present environmental and regulatory challenges for installations that contain SAFRs, depending on the physical and chemical properties of the soil, and the proximity of the berm to sensitive environmental receptors. All of the lead entering a berm on a firing range initially is present as metallic lead alloy. As the metallic lead ages within the SAFR berm it undergoes corrosion processes that can result in the release of dissolved lead cations and other metals. Depending on the environment within the berm, the fate of dissolved lead can range from transport to groundwater as soluble lead, transport to surface water as soluble lead, sorption onto electronegative particle surfaces (e.g., clays, organic matter, iron or manganese oxides), precipitation of lead salts (e.g., carbonates, sulfates, sulfides, and phosphates).

Generally, the mobility of dissolved lead is controlled by $\mathrm{pH}$ conditions, adsorption/ desorption of lead with soil particles, and advective processes such as groundwater or surface-water flow. When conditions aren't optimal, the installation may face regulatory issues, with lead or other heavy metals, potentially being transported off-site (Figure 1). Low pH soil 


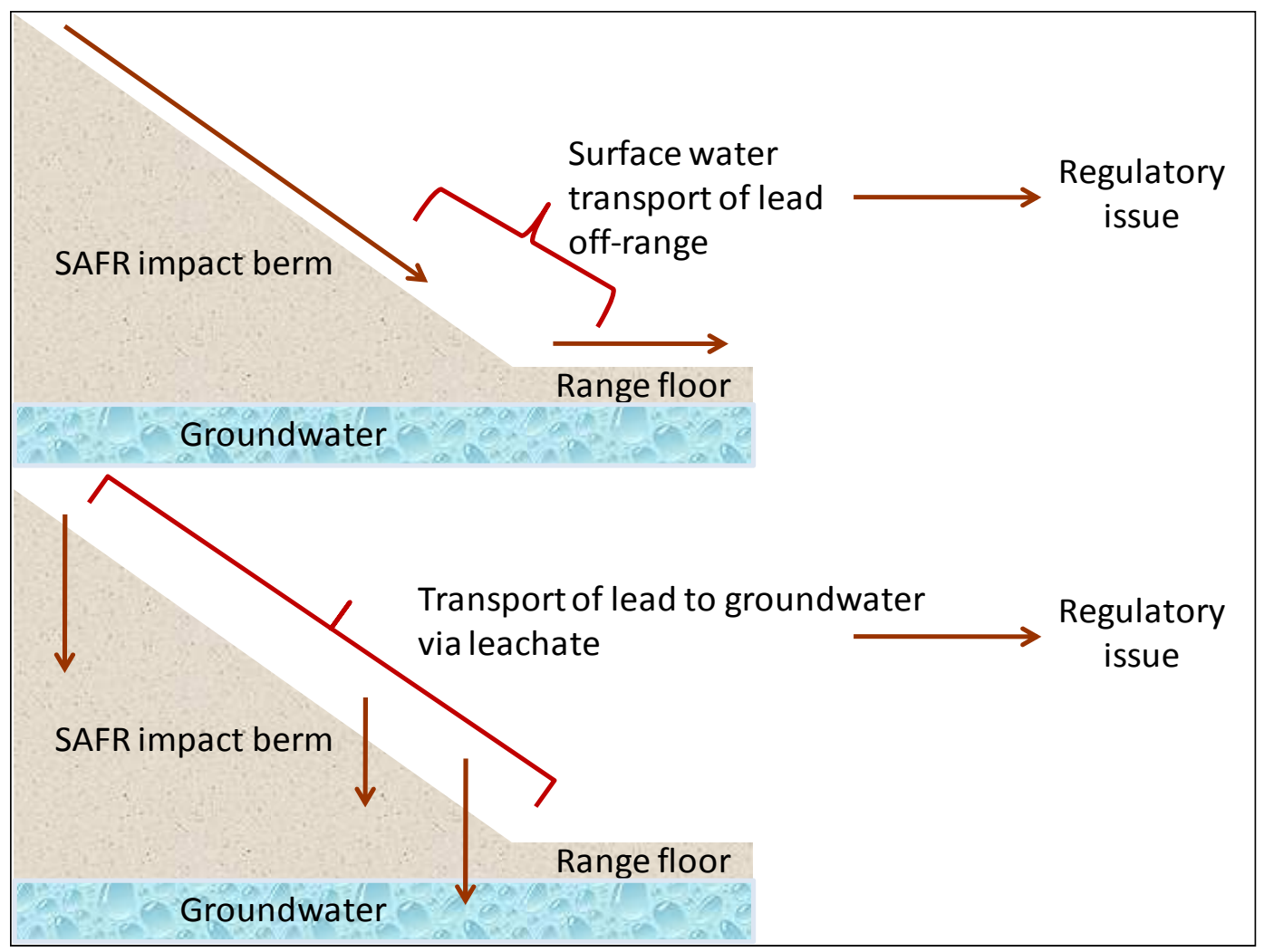

Figure 1. Potential compliance isues on small arms firing ranges.

(acidic soils) generally enhances solubility of $\mathrm{Pb}, \mathrm{Cu}$, and $\mathrm{Zn}$, while neutral to basic $\mathrm{pH}$ conditions tend to favor the precipitation of metal salts (Anderson and Christensen 1988, Carlon et atl 2004, Impelliteri et al. 2002, J anssen et al. 1997). Soils rich in clay and/ or organic matter (i.e., those possessing a net negative charge) typically exhibit high soil/ water distribution coefficients ( $\mathrm{K}_{\mathrm{d}}$ values) for metals such as $\mathrm{Pb}$ and $\mathrm{Cu}$, and may thus be effective in retarding their migration to the surrounding environment (Covelo et al. 2007, Hooda and Alloway 1998, Moreno et al. 2006). Iron, however, behaves in the opposite manner; the $K_{d}$ is decreased in the presence of high concentrations of clay/ organic matter (Chen et al. 2006). The erosion and transport of lead-contaminated soils by surface runoff (especially those soils containing a high proportion of silt and clay) can result in the redistribution of lead over relatively large distances.

Soils that are characterized by either high acidity (low $\mathrm{pH}$ ), high alkalinity (high $\mathrm{pH}$ ), high permeability, and (or) low soil/ water $\mathrm{K}_{\mathrm{d}}$ values for lead may be ineffective in retarding the migration of soluble lead into nearby groundwater or surface water bodies. Mechanical erosion and transport of such soils (especially clay-rich soils) may also lead to offsite transport of lead in surface water runoff (Table 1). Conversely, soils characterized by 
neutral to slightly basic $\mathrm{pH}$ conditions, relatively low permeability, and (or) which exhibit a high $\mathrm{K}_{\mathrm{d}}$ value for lead may be effective in limiting the mobility of soluble lead to the surrounding environment (Figure 2).

Table 1. Soil chemistry that promotes transport of Pb off-range in surface water and to groundwater via leachate.

\begin{tabular}{|l|l|}
\hline Surface water transport & Leachate transport \\
\hline High CEC & Low CEC \\
\hline High percentage of fines (small particle size) & Lower percentage of fines \\
\hline Extreme pH (acid or alkaline) & Extreme pH (acid or alkaline) \\
\hline Low permeability & High permeability \\
\hline High sorption capacity (high $\left.\mathrm{K}_{d}\right)$ & Low sorption capacity (low $\mathrm{K}_{\mathrm{d}}$ ) \\
\hline Potential problem soil types: Silt, clay soils & Potential problem soil types: Sandy soils \\
\hline Regulatory Issue & Regulatory Issue \\
\hline
\end{tabular}

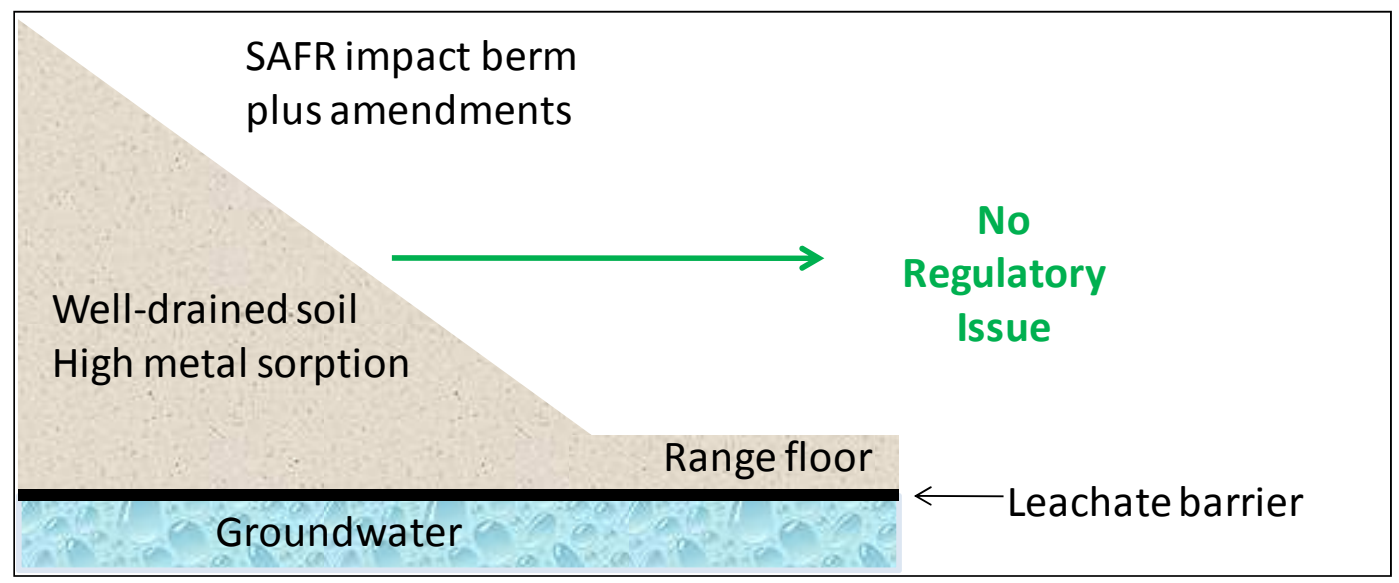

Figure 2. Effect of PRBerm ${ }^{\mathrm{TM}}$ technology on regulatory compliance issues.

\section{Impact Berm Deceleration Media}

Washed, construction sands that consist principally of silicate minerals (e.g., quartz) - such as those commonly used in masonry and concrete manufacture - may provide a suitable medium for the construction or replacement of SAFR impact berms. Commencially available masonry or concrete sands are relatively low-cost materials and are widely available due to their extensive use in construction. From an operational standpoint, sand has numerous beneficial properties as a deceleration medium at firing ranges, and is generally the material of choice for this purpose. Impact berms made from sand are effective in decelerating fired projectiles safely, with minimal fragmentation, a low risk of ricochet, and relatively little dust 
generation. The chemical inertness of silicate sands minimizes berm cementation and hardening, thus ensuring proper deceleration of projectiles. Further, the granularity, low bulk density, and non-cohesive nature of sand facilitate the separation of spent bullet fragments during range maintenance or clearance activities (e.g., by soil screening). Finally, the refractory and non-flammable nature of sand provides additional benefits in ranges where tracer rounds may be used.

From an environmental perspective, the use of silicate mineral sand offers three principal benefits:

1. Washed sand typically contains a low proportion of silt and clay-sized particles, which reduces the potential for $\mathrm{Pb}$ transport by storm water runoff.

2. The relatively high hydraulic conductivity of sand minimizes the amount of surface runoff down the berm face.

3. The drainage characteristics (combination of the high permeability and low specific retention) of sand tend to limit the contact time between water and $\mathrm{Pb}$ particles, thus inhibiting the in-situ corrosion (weathering) of $\mathrm{Pb}$.

However, from an environmental standpoint, there are a number of disadvantages associated with the use of sand in SAFR berms:

1. Most silicate mineral sands have a negligible $\mathrm{pH}$ buffering capacity. The lack of an adequate buffering capacity could lead to a reduction of soil $\mathrm{pH}$ to levels where both the rate of $\mathrm{Pb}$ corrosion and extent of $\mathrm{Pb}$ solubility in water are significantly increased. For this reason, $\mathrm{Pb}$ present in an unamended sand berm would be susceptible to leaching by acid precipitation (acid rain).

2. Commercially available washed construction sands typically contain relatively low proportions of clay, silt, and organic (humic) material, and are thus the washed sand is characterized by relatively low $K_{d}$ values.

3. Further, unamended silicate sands generally contain minimal amounts of carbonates, iron and manganese oxides, sulfides, organic matter, and phosphate compounds, and are generally ineffective in retarding $\mathrm{Pb}$ mobility through precipitation reactions and are also difficult to vegetate.

Thus, SAFR berms constructed entirely of unamended silicate sand may be more likely to release soluble $\mathrm{Pb}$ into the environment than berms that are constructed using other soil types. This shortcoming can be addressed by 
amending construction sand with materials that will buffer soil $\mathrm{pH}$, enhance $\mathrm{Pb}$ adsorption, and (or) promote the precipitation of stable $\mathrm{Pb}$ salts.

\section{Phosphate Amendments}

The bioavailability and environmental risk of a contaminant are directly related to its accessibility to the biota in the soil medium, which is generally controlled by its solubility and mobility (Traina and Laperche 1999). Linking $\mathrm{Pb}$ bioavailability to its solubility rather than to its total concentration makes possible the consideration of remediation strategies based on in situ reduction of contaminant solubility, rather than its complete removal or physical isolation (solidification). Due to the high costs of soil excavation and off-site remediation, in situ chemical stabilization with phosphorus (P) based amendments has been investigated as a more efficient and costeffective method of site remediation (Wilson et al. 2006, Hettiarachchi et al. 2002, Traina and Laperche 1999, Berti and Cunningham 1997, Ma and Rao 1997). Phosphorous-based amendments have been shown to reduce the lead bioavailability to allowable levels through the conversion of relatively soluble/ bioavailable forms of lead to relatively insoluble/ less bioavailable pyromorphites $\left(\mathrm{Pb}_{5}\left(\mathrm{PO}_{4}\right)_{3} \mathrm{X}_{(\mathrm{s})}\right.$, where $\left.\mathrm{X}=\mathrm{Cl}^{-}, \mathrm{F}^{-}, \mathrm{OH}-\right)$, the most stable forms of lead in oxic surface soils under a wide range of environmental conditions (Traina and Laperche 1999). Although phosphorous amendments have mainly been applied to remediate $\mathrm{Pb}$-contaminated soil, they may also be applicable to other metals associated with firing-range soils such as $\mathrm{Cd}, \mathrm{Zn}$, and $\mathrm{Cu}$ (Hamon et al. 2002).

Several laboratory and bench-scale remediation studies have demonstrated the effectiveness of the addition of phosphate-based soil amendments in producing highly insoluble $\mathrm{Pb}$ phosphate minerals such as pyromorphite and hydroxypyromorphite (Berti and Cunningham 1997, Lambert et al. 1997, Ma and Rao 1997, Lower et al. 1998, Traina and Laperche 1999). When sequestered within these phosphate minerals, $\mathrm{Pb}$ has been shown to be far less soluble, as indicated by the results of acid leaching tests (Tardy et al. 2003). Its bioavailability to soil organisms has been demonstrated to be sharply reduced (Berti and Cunningham 1997, Pearson et al. 2000, Traina and Laperche 1999). The U.S. Environmental Protection Agency (USEPA) has recognized that the bioavailability of $\mathrm{Pb}$ in contaminated soils varies greatly depending upon its form in the soil. USEPA has suggested that phosphate treatment has the potential for in situ remediation of metals contaminated soils and sediments (USEPA 2001b). 
Lead is amphoteric and $\mathrm{Pb}$ compounds show the greatest aqueous solubility at the acidic $(\mathrm{pH}<4)$ and alkaline $(\mathrm{pH}>11)$ ranges. Under acidic conditions, elemental $\mathrm{Pb}$ will dissolve, releasing a hydrated cation $\mathrm{Pb}^{2+}$. Under alkaline conditions, elemental $\mathrm{Pb}$ will dissolve, theoretically forming the dissolved hydroxide complex $\mathrm{Pb}(\mathrm{OH})_{3}{ }^{3}$ and ion-pair $\mathrm{Pb}(\mathrm{OH})_{2}$ (aqueous) (ITRC 2003).

Several factors affect the amount of $\mathrm{Pb}$ that is dissolved in water. In a typical water body, dissolved $\mathrm{Pb}$ forms precipitates of $\mathrm{Pb}$ hydroxide $\left[\mathrm{Pb}(\mathrm{OH})_{2}\right], \mathrm{Pb}$ carbonate $\left[\mathrm{PbCO}_{3}\right.$, cerrusite], or basic $\mathrm{Pb}$ carbonate $\left[\mathrm{Pb}_{3}(\mathrm{OH})_{2}\left(\mathrm{CO}_{3}\right)_{2}\right.$, hydrocerrusite]. Overall $\mathrm{Pb}$ solubility in a natural system is fundamentally determined by the concentrations of the anions in solution (e.g., the hydroxide and carbonate ions) and by the ionic strength of the solution, which affects the activity coefficients of the ions. These factors can be related to more directly measured parameters such as $\mathrm{pH}$, alkalinity, and total dissolved solids (TDS) (Vaccari 1992).

In any system having water in equilibrium with a solid phase, the metal precipitate that has the lowest solubility will be the only stable solid phase and will increase in its relative concentration at the expense of the more soluble forms. Thus, the presence of $\mathrm{Pb}$ with extremely low solubilities, such as $\mathrm{Pb}$ phosphates, influences the solubility and availability of the $\mathrm{Pb}$ in the environment.

The metalloid, antimony (Sb), has also been detected in shooting range soil at high concentrations (Ackermann et al. 2009, Dermatas et al. 2006, J ohnson et al. 2005, Kilgour et al. 2008, Klitzke and Lang 2009). Antimony is added to lead alloy bullet as a hardening agent. Subseqently, Sb is released - along with $\mathrm{Pb}$ - during the bullet corrosion process. However, unlike the cation of $\mathrm{Pb}, \mathrm{Sb}$ forms an oxyanion and the geochemistry is quite different from that of $\mathrm{Pb}$. The geochemistry has been reviewed by Wilson et al. (2010). Antimony is reported to be associated with ferrihydrates, carbonates and oxides in soil. High $\mathrm{pH}$ (alkaline conditions) and anoxic conditions increases the dissolution of these complexes and leads to the release of Sb in to the soil pore water and surface water (Chen et al. 2003, J ohnson et al. 2005). Therefore, in conditions of well-drained soil, with high concentrations of free carbonate and iron, a low percentage of clays and fines, and a low pH, Sb transport should not be of great concern. However, when soil is amended with $\mathrm{P}$ for immobilization of $\mathrm{Pb}$, the $\mathrm{Sb}$ may inadvertently be mobilized through competitive reactions with the $\mathrm{P}$ (Kilgour et al. 2008). 


\section{Thermally Treated Fishbones (TFF)}

Fishbone is a form of biogenic apatite produced, mechanically or enzymatically, from fish industry by-products. This results in a composition of clean and dried fish bone and fish hard parts. A study conducted by Shinomiya et al. (1998) investigated the eventual demineralization of mammal bones buried underground for 2 years and determined that phosphorous concentrations initially decreased within the bone and then increased, potentially due to nucleation sites provided by the bone material (Wright et al. 2004). As a soil amendment, fishbone Apatite $\mathrm{II}^{\mathrm{TM}}$ has several advantages over other forms of natural apatite and terrestrial bone sources (e.g., cow bone). Apatite II ${ }^{\mathrm{TM}}$ has low trace metals concentrations and exhibits poor crystallinity compared to other naturally occurring forms of apatite (Conca et al. 2000). Unlike cow bones, Apatite II ${ }^{\mathrm{TM}}$ is highly microporous (Wright et al. 2004; Lu et al. 2001), and thus provides a readily available and reactive source of soluble phosphates along with a potential seed crystal for heterogeneous nucleation of lead-pyromorphites (Wright et al. 2004). Depending on the presence of certain metals in solution, a $\mathrm{Pb}$ removal efficiency of 37 to 100 percent can be achieved through the process of hydroxyapatite dissolution and hydroxypyromorphite $\left[\mathrm{Pb}_{10}\left(\mathrm{PO}_{4}\right)_{6}(\mathrm{OH})_{2}\right]$ precipitation (Ma et al. 1994; Wright et al. 2004).

The fishbones used in this study were thermally treated in a muffle furnance at $450{ }^{\circ} \mathrm{C}$ to remove any organic matter present to conduct the study at CAFB.

\section{TRAPPS ${ }^{\mathrm{TM}}$}

TRAPPS $^{\mathrm{TM}}$ is a commercially available off-the-shelf (COTS) product, a formulation of apatite and other insoluble phosphate mineral, in which lead is precipitated as stable pyromorphite. According to the manufacturer, TRAPPS $^{\mathrm{TM}}$ also does not cause increased mobilization of copper, arsenic, and antimony or release excessive amounts of phosphate

(http://www.slateruklimited.co.uk/us/trapps_firing_range.html).

\section{Metal Oxide Amendments}

Hydrous oxides of aluminum (Al), iron ( $\mathrm{Fe}$ ), and manganese (Mn) are ubiquitous in soils and strongly implicated in the sorption of metals and a reduction in metal mobility in soil systems (Bradl 2004, Covelo et al. 2007, Ford et al. 1997, Han et al. 2006, Martinez and McBride 1998, Martinez et 
al. 1999, Ndiba et al. 2008, Orsetti et al. 2006, Trivedi and Axe 2000). The highest adsorption is found from $\mathrm{Pb}$ and $\mathrm{Cu}$; the least adsorption from $\mathrm{Cd}$, $\mathrm{Ni}$, and Zn (Covelo et al. 2007, Ford et al. 1997, Martinez and McBride 1998). Cadmium and $\mathrm{Zn}$ were not affected by changes in soil $\mathrm{pH}$ but $\mathrm{Cu}$ solubility increased (desorption) as the soil pH decreased. The iron hydroxides are generally determined to be more effective at immobilizing $\mathrm{Pb}$ and less effective at immobilizing $\mathrm{Cd}$ and $\mathrm{Cu}$. However, as the metal oxides aged, the $\mathrm{Pb}$ was reported to undergo desorption. Unlike $\mathrm{Pb}$, which had rapid intial sorption into ferrihydite, the metals with lower initial sorption ( $\mathrm{Mn}$ and $\mathrm{Ni}$ ) became incorporated into the more stable iron minerals goethite and hematite and remained immobilized (Ford et al. 1997, Martinez and McBride 1998).

Copper, $\mathrm{Pb}, \mathrm{Ni}$ and $\mathrm{Zn}$ have also been reported to adsorb to Mn-oxide. Manganese oxide is a surface acidic oxide with a $\mathrm{pH}_{\mathrm{pzc}}$ (point of zero charge) of approximately 1.5 to 4.5 (Han et al. 2006). Soil amendment with phosphate reduced the leachability of these complexes by $89 \%$ compared to controls (Ndiba et al. 2008).

\section{Regulatory Drivers}

The regulatory drivers at CAFB M60 range were derived from a study that was initiated at the Barksdale Air Force Base (BAFB) located near Bosier City, Louisiana. The BAFB state-based surface water regulations served as a benchmark throughout the bench scale, treatability, and field demonstration studies. The regulations used in the field study are listed below (Larson et al. 2007):

- Total lead discharge limit of $0.15 \mathrm{mg} / \mathrm{L}(150 \mathrm{\mu g} / \mathrm{L})$

- Copper discharge limit of $0.5 \mathrm{mg} / \mathrm{L}$ (500 $\mathrm{\mu g} / \mathrm{L}$ )

- Total Organic Carbon (TOC) discharge limit of $50 \mathrm{mg} / \mathrm{L}$

- $\mathrm{pH}$ between 6.0 and 9.0 for the discharge

Total Suspended Solids (TSS) was not a required measurement but since it is an important indicator of the potential metals leaving the range, TSS was an additional parameter that was evaluated. Research performed by the Engineer Research and Development Center - Environmental Laboratory (ERDC-EL) has shown that the majority of the lead in the runoff water occurs as insoluble lead associated with suspended (colloidal) soil particles (Larson et al. 2007). 
Amendments can be added to the berm materials (sand or local soil) to aid in the immobilization or stabilization of metals associated with the bullets used at a SAFR. Several amendments are available for in situ and ex situ stabilization; however, the long-term - and often the actual — effects of SAFR training on the longevity of the amendments are seldom evaluated. Two amendments were tested in this study using ballistic sand as the impact media of the berm. These amendments were TRAPPS ${ }^{\mathrm{TM}}$ and thermally treated fish bones (TTF) which provide theoretically insoluble metal complexes. The leachate and runoff samples were collected and measured for metals concentrations, TSS, and $\mathrm{pH}$. 


\section{Experimental Design}

\section{Technology Development}

Treatability studies conducted by ERDC-EL (Larson et al. 2007a) evaluated sand amendments under laboratory and mesoscale conditions to determine optimum combinations to immobilize soluble metals, such as $\mathrm{Pb}$, in situ. These studies determined that the sand to amendment ratio of $5 \%(\mathrm{w} / \mathrm{w})$ was sufficient to contain greater than $90 \%$ of soluble $\mathrm{Pb}$ within the berm material. Lysimeter studies then used regulated artificial rain events to evaluate the metals concentrations, total suspended solids, dissolved organic carbon, and runoff and leachate $\mathrm{pH}$ over time for the amended and sand-only (control) berms. Several phosphate-based amendments were evaluated, including Whole Bone and Crushed Bone Apatite II ${ }^{\mathrm{TM}}$. By comparing the metals concentrations remaining in solution after 18 hours of tumbling in the toxicity characteristic leaching procedure (TCLP) extraction solution against control soils with no amendments, the amended soils decreased the leaching of $\mathrm{Pb}$ from 45 to 99 percent. While all of the amended soils achieved or bettered the TCLP regulatory limit of $5 \mathrm{mg} / \mathrm{L}$ for $\mathrm{Pb}$ leaching, the apatite-based amendment was most effective at the lowest amendment loading rates.

Apatite II ${ }^{\mathrm{TM}}$ and TTF were further investigated for its ability to sequester $\mathrm{Pb}$ from solution (Martin et al. 2008). The study reported that organic compounds were formed in the apatite-amended lysimeters during aging and this hindered $\mathrm{Pb}$ immobilization. Because Apatite $\mathrm{II}^{\mathrm{TM}}$ is known to contain up to $40 \%$ residual organics (Conca and Wright 2006), the fish bones were treated using several different methods to remove the residual organics. Laboratory and column studies established that thermally treated Apatite $\mathrm{II}^{\mathrm{TM}}$ prior to use as an amendment allowed for consistent removal, $>90 \%$, of soluble lead from solution and reduced the biological oxygen demand (BOD) of the solutions to non-detect levels. For this reason, it was chosen as one of the soil amendments in the PRBerm $^{\mathrm{TM}}$ field demonstration.

\section{Technology Description}

A typical impact berm cross-section with the PRBerm ${ }^{\mathrm{TM}}$ technology application, Figure 3 includes a non-woven geo-membrane / fabric that 
serves as a barrier between native soils and ballistic (i.e., sand,media). Amended sand is placed on top of the newly contoured earthen berm. A $\mathrm{SACON}^{\circledR}$ or timber toe support can be used at the base of the PRBerm ${ }^{\mathrm{TM}}$ to prevent excessive sand erosion from the berm.

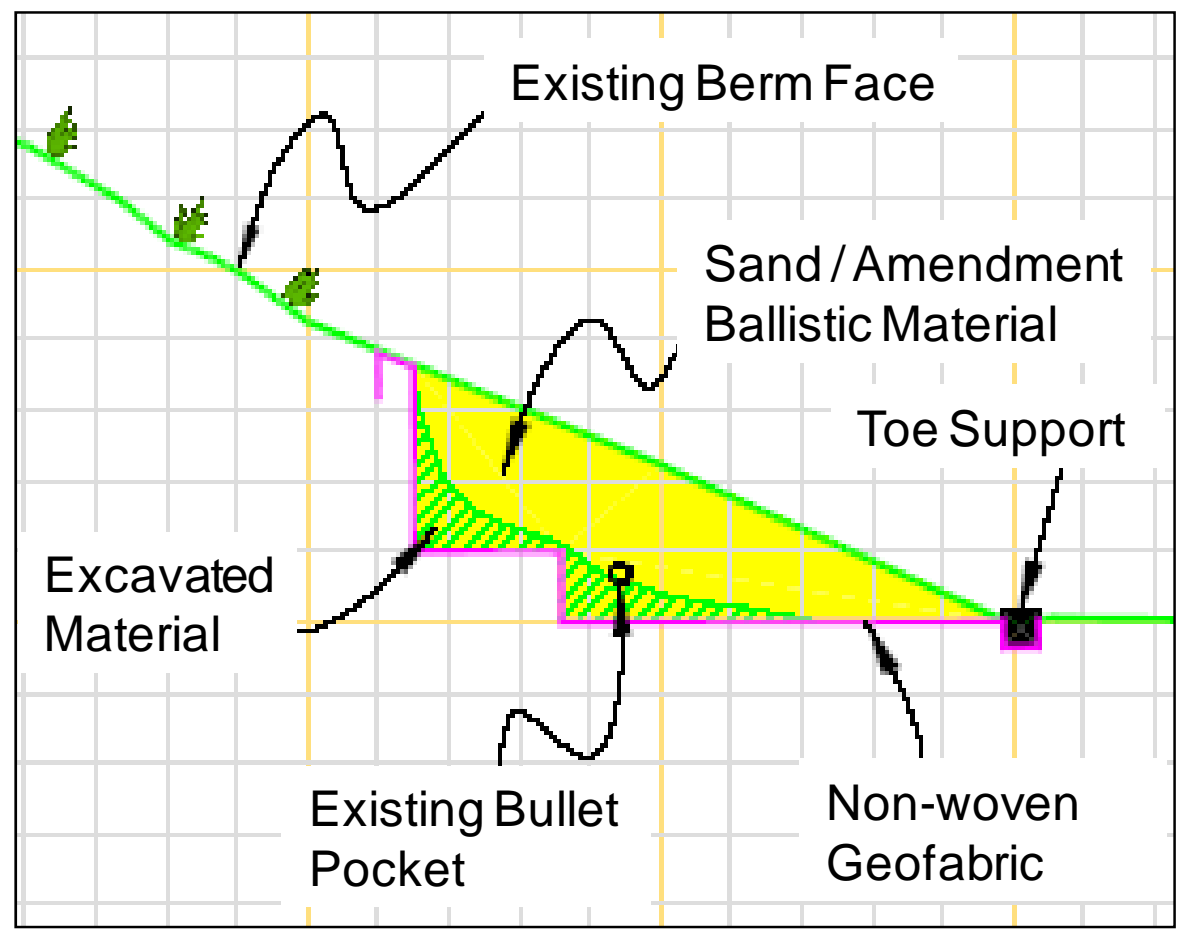

Figure 3. Schematic cross xection of Charleston AFB PRBerm ${ }^{\mathrm{TM}}$ technology application.

Pre-construction views of the CAFB M-60 range are provided in Figures 4 and 5. The three firing positions of the CAFB M-60 training range allowed the testing of three different evaluations of the PRBerm ${ }^{\mathrm{TM}}$ technology. Based on the results of the treatability study, two combinations of amendments were tested and compared to a control (untreated berm). The amendments were TRAPPS ${ }^{\mathrm{TM}}$, and TRAPPS ${ }^{\mathrm{TM}}$ plus thermally treated fish bones. The control cell was constructed without amendments in order to provide statistical data for the performance assessment.

The PRBerm ${ }^{\mathrm{TM}}$ at CAFB contains 20 foot connex lysimeters that hold the sand and test amendments and are used to collect runoff water and leachate water from the berm through a sample collection system.

Surface water and leachate were sampled from the control and amended berms and analyzed for heavy metals (total and dissolved), TOC, TSS, and $\mathrm{pH}$. 


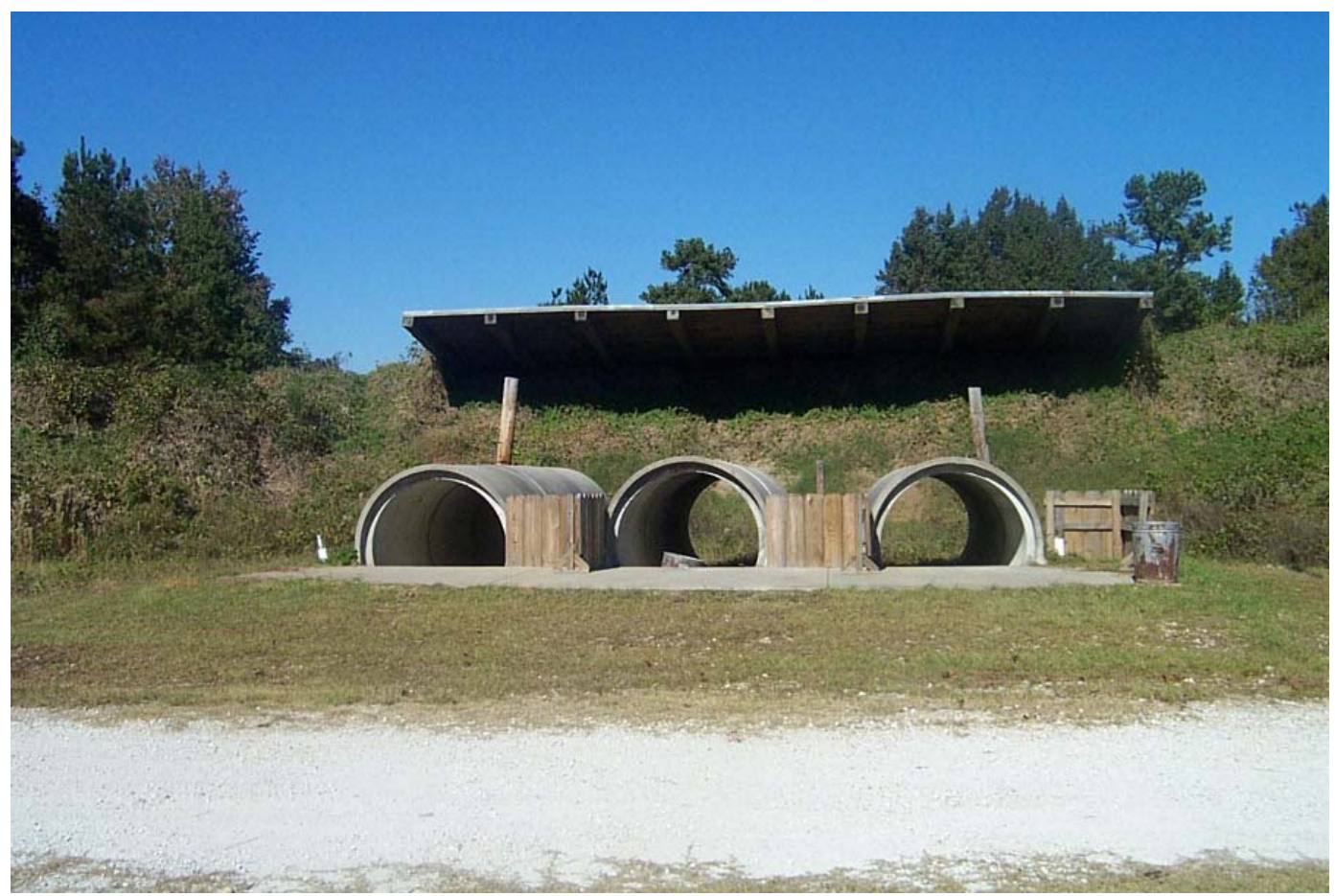

Figure 4. Pre-construction view of the three firing points and impact berm area at the CAFB range. View is through the individual firing positions towards the impact berm.

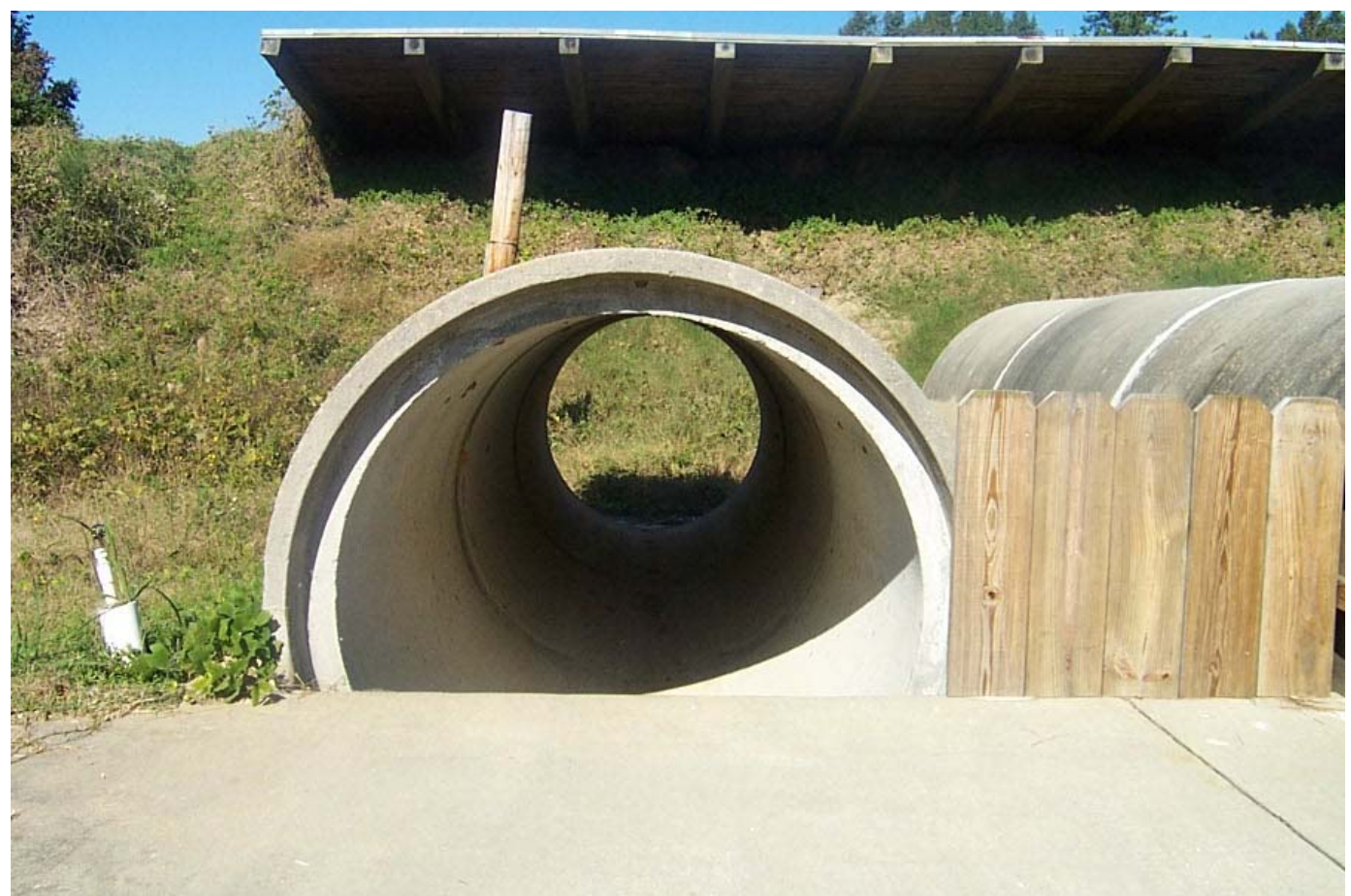

Figure 5. Pre-construction close up view through the pipe that forms the firing line and looking towards the berm. 


\section{Study Objectives}

The objectives of the field demonstration were to a provide a field demonstration for the PRBerm ${ }^{\mathrm{TM}}$ technology, to assess the environmental benefits, feasibility, and cost of using sand as a deceleration medium in SAFR berms in conjunction with amendments designed to retard the migration of $\mathrm{Pb}$ into the surrounding environment. The amendments provide for reduction of $\mathrm{Pb}$ solubility through $\mathrm{pH}$ buffering of pore fluids within the SAFR berm, as well as the sequestration of $\mathrm{Pb}$ through surface adsorption and the precipitation of insoluble $\mathrm{Pb}$ salts. This technology application is known as a passive reactive berm $\left(\mathrm{PRBerm}^{\mathrm{TM}}\right)$.

The purpose of the field demonstration was to provide range operators with an economical means of controlling the off-site migration of $\mathrm{Pb}$, while maintaining the benefits of sand as a deceleration medium. In particular, this technology was designed to address sites where the native soils available for SAFR berm construction either lack the characteristics necessary to retard the migration of soluble $\mathrm{Pb}$ (e.g. acidic soils) or are susceptible to erosion and off-site transport of $\mathrm{Pb}$ as a result of their high clay content. 


\section{Materials and Methods}

\section{Charleston Air Force Base (CAFB) M-60 Range}

The Charleston Air Force Base, also known as J oint Base Charleston, is a United States Air Force base located in North Charleston, South Carolina (Figure 6). Charleston Air Force Base originated when the city of Charleston purchased land in 1931 to build Charleston Municipal Airport. On 11 December 1941, the Army Air Corps took control of the field and antisubmarine missions were being flown out of Charleston Army Air Field by August 1942. Returned to civilian control after World War II, the United States Air Force began joint use of the facility on 11J uly 1952 and the military part of the airfield was renamed Charleston Air Force Base on 1J une, 1953.

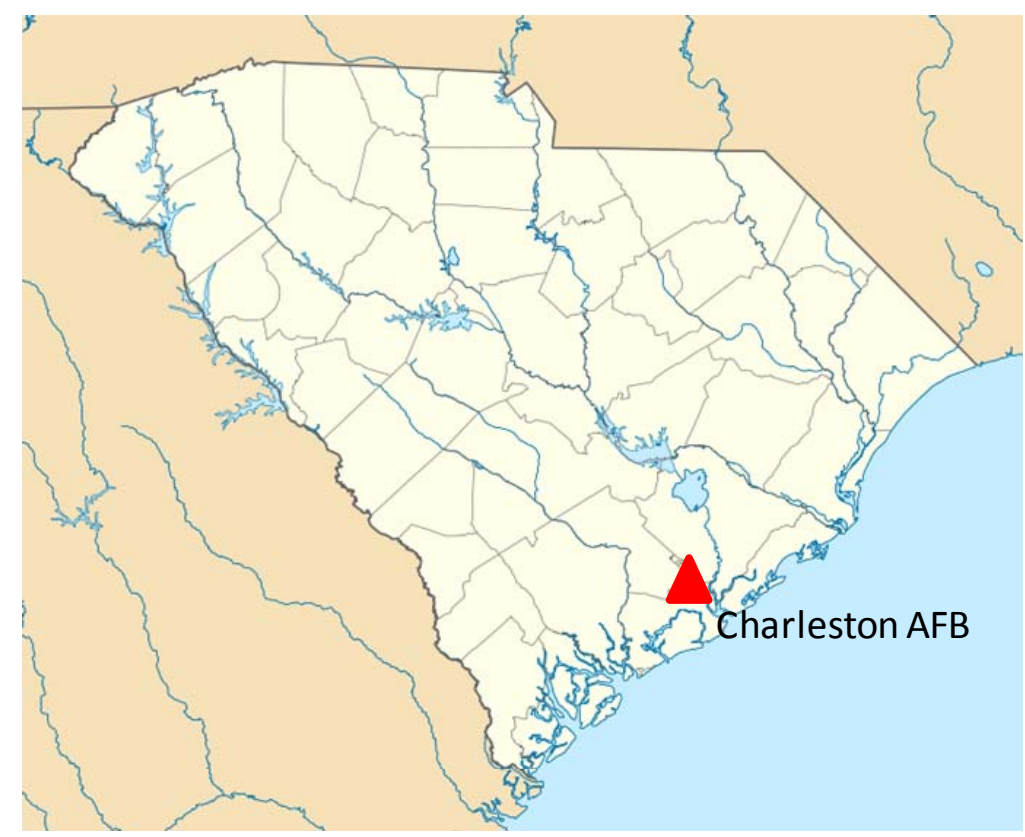

Figure 6. Location of Charleston AFB, SC.

Charleston AFB is assigned to Air Mobility Command (AMC). A joint civilmilitary airport, Charleston AFB shares runways with Charleston International Airport for commencial airline aircraft operations on the south side of the airfield and general aviation aircraft operations on the east side (Figure 7). Charleston AFB is home to J oint Base Charleston 628th Air Base Wing (628 ABW) the "host wing for installation support." 


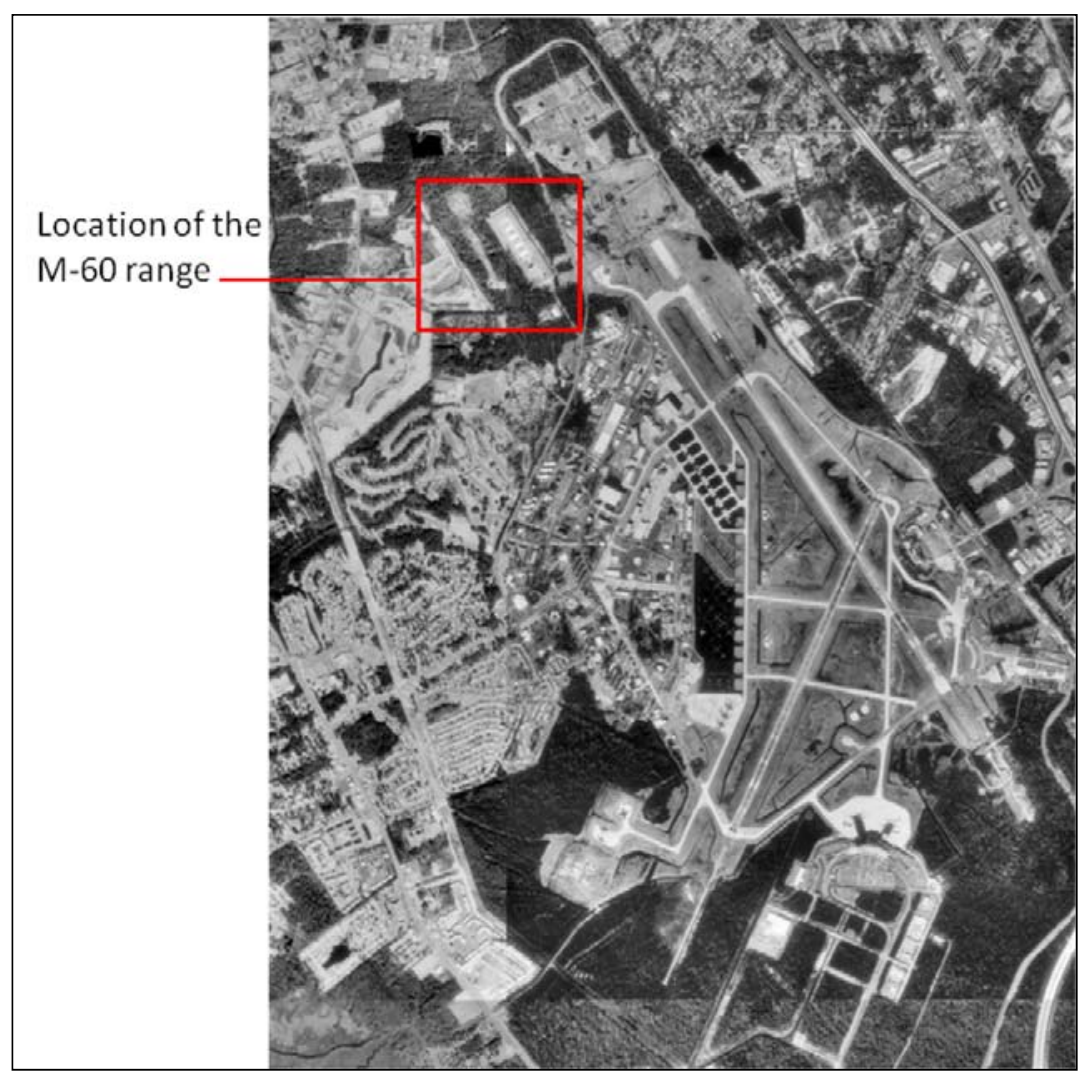

Figure 7. Aerial view of the Charleston Air Force Base with the location of the $M-60$ range indicated within the red box.

The Charleston AFB M-60 range contains three fixed firing positions that are used for the qualification/ familiarization of the 5.56mm (M249) and 7.62mm (M240) weapons systems. Live fire is directed toward an earthen impact berm through 6-foot diameter reinforced concrete pipes that are approximately 24 feet in length. Typically the CAFB personnel fire more than 100,000 rounds of $5.56 \mathrm{~mm}$ and/ or $7.62 \mathrm{~mm}$ ammunition per year for qualification/ familiarization purposes with the range safety danger zone (SDZ) depicted in Figure 8.

The range was closed for renovations prior to the PRBerm ${ }^{\mathrm{TM}}$ field demonstration. During the years of closure, weapons upgrades and base operations encroachment had decreased the safety area (i.e., SDZ) around the firing range. The protective eyebrow over the firing positions was no longer adequate to protect surrounding areas from ricochet hazard as observed in the ricochet safety design illustrated in Figure 9. 


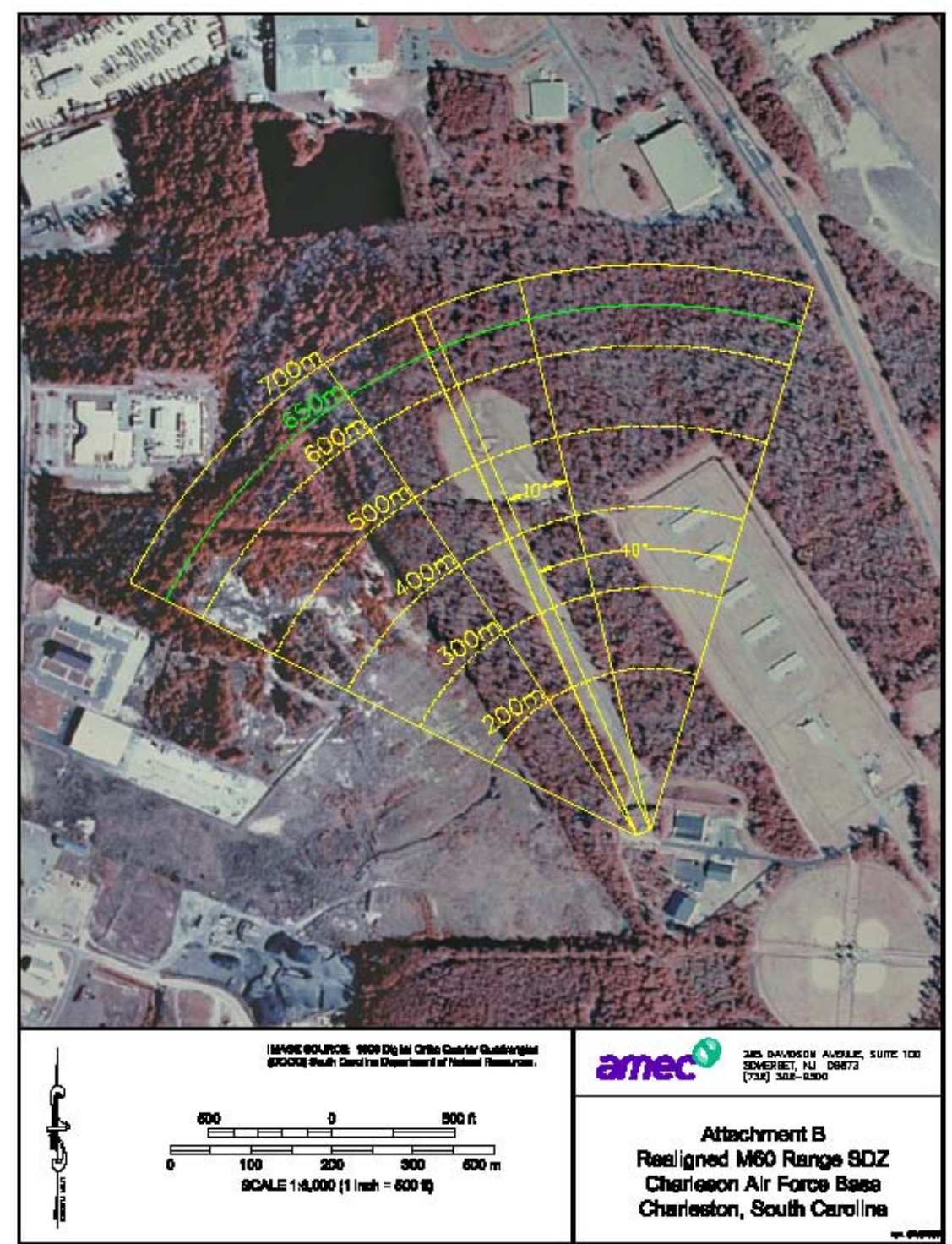

Figure 8. Aerial view of the M-60 range at Charleston AFB indicating possible bullet firing distances.

There is an underground drain at the $\mathrm{M} 60$ range that allows the range runoff water to flow under a nearby road and into a stormwater drainage system nearby. The drainage system located at the range provided adequate storm water collection system for runoff water samples leaving the range complex and prevented potential cross contamination of leachate water collection systems (i.e., on-site pooling of water).

\section{Berm Amendments}

Two amendments were selected for field testing at the CAFB M-60 range: TRAPPS $^{\mathrm{TM}}$ (Slater, UK) and thermally treated fish bones (TTF). 


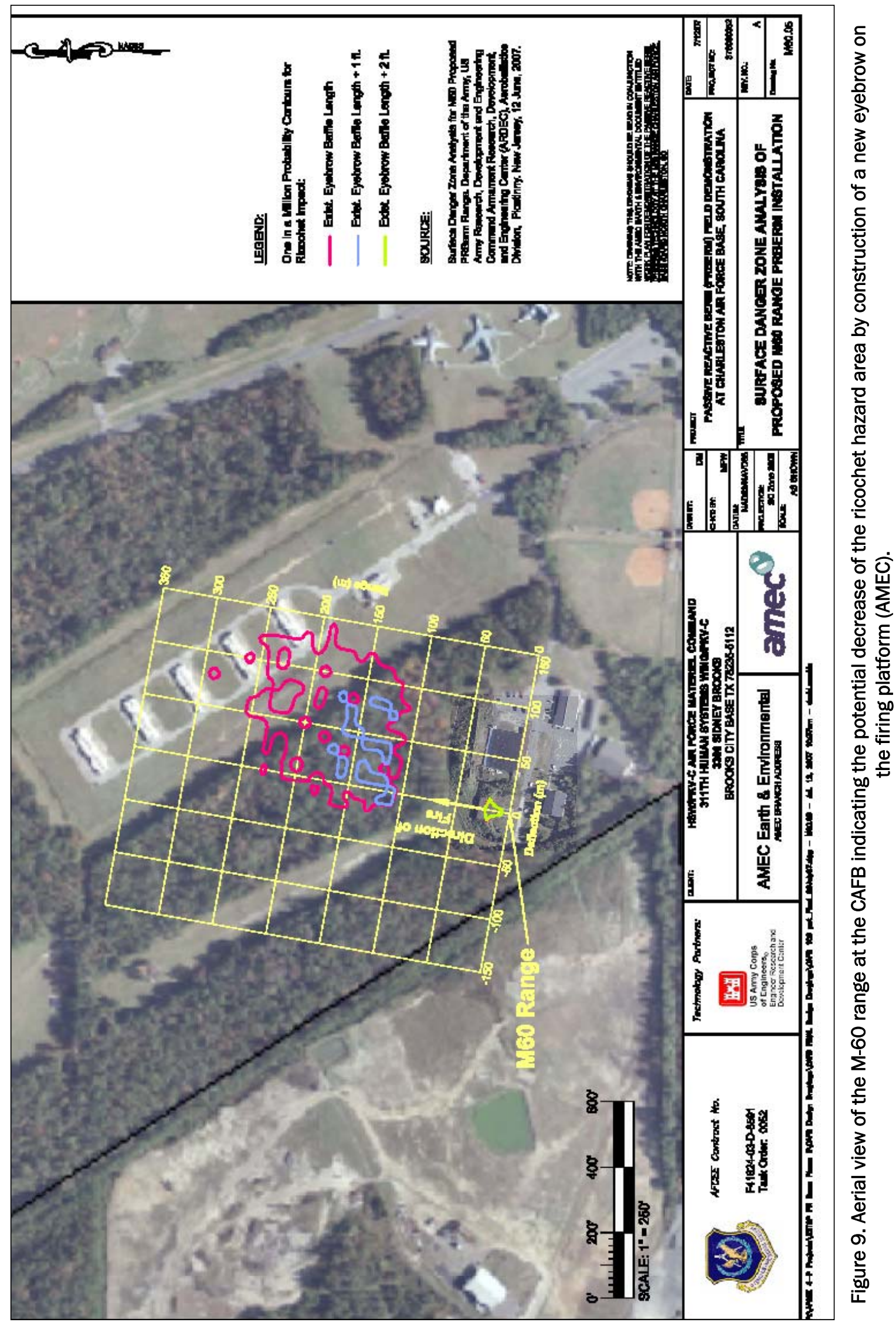


The TRAPPS ${ }^{\mathrm{TM}}$ amendment would be tested alone and with the addition of the TTF. TRAPPS ${ }^{\mathrm{TM}}$ is a COTS product, a formulation of apatite and other insoluble phosphate mineral, in which lead is precipitated as stable mineral (e.g. pyromorphite). According to the manufacturer, TRAPPS ${ }^{\mathrm{TM}}$ also does not cause increased mobilization of copper, arsenic, and antimony or release excessive amounts of phosphate (Slater, UK 2010).

The second amendment is thermally treated fish bones (TTF). Fishbone is a source of biogenic apatite known to sequester lead from solution (Martin et al. 2008). Thermal treatment removes organic carbon that interferes with lead sorption sites. This increases the treatment effectiveness over the longterm versus increased product cost in the short-term. The TTF was also found, in bench-scale studies, to achieve the regulatory TCLP discharge limit for lead. The use of a limited amount of the TTF in this study provided another opportunity to explore the effects of the TTF on heavy metal immobilization through the TCLP analysis.

\section{Lysimeter Construction}

The three lysimeters placed inside the impact berm of the M6-0 range were constructed from International Organization for Standardization (ISO) Standard 20-foot by 8-foot insulated containers by Sea Box, Inc., located in East Riverton NewJ ersey (Figure 10). The lysimeters were designed for the collection of surface runoff water and leachate. The lysimeters were lined with stainless steel interior and equipped with aluminum " $\mathrm{t}$ " channel floors. Polyethylene sheets were placed inside of each lysimeter to create an impermeable lining to the lysimeter and to ensure that the leachate drained towards the well screen located at the down-slope end of the lysimeter. For piping, a 4-inch diameter Schedule 80 polyvinyl-chloride (PVC) "0.010 slot" was wrapped in geotextile fabric. The leachate collection piping passed through the lysimeter walls using water-tight bulkhead fittings sealed with a solvent-weld (Figure 11). The existing drain openings in the bottom of the container were plugged with removable stoppers. The door end of each container was cut back to match the slope of the final grade of the berm face (1:2), and the cut edges of the walls were capped with aluminum.

Construction details of the leachate collection system are shown in Figures 11 and 12. For the lysimeter that contained both TRAPPS ${ }^{\mathrm{TM}}$ and thermally treated fish bones, a high-density polyethylene lysimeter measuring $0.787 \mathrm{~m}$ ( $31 \mathrm{in}$.) by $0.787 \mathrm{~m}$ by $0.609 \mathrm{~m}$ ( $24 \mathrm{in}$.) was placed inside of the stainless steel lysimeter. The polyethylene lysimeter contained $5 \%$ TTF. Separate leachate collection piping was attached to the stainless steel lysimeter and the polyethylene lysimeter insert. 


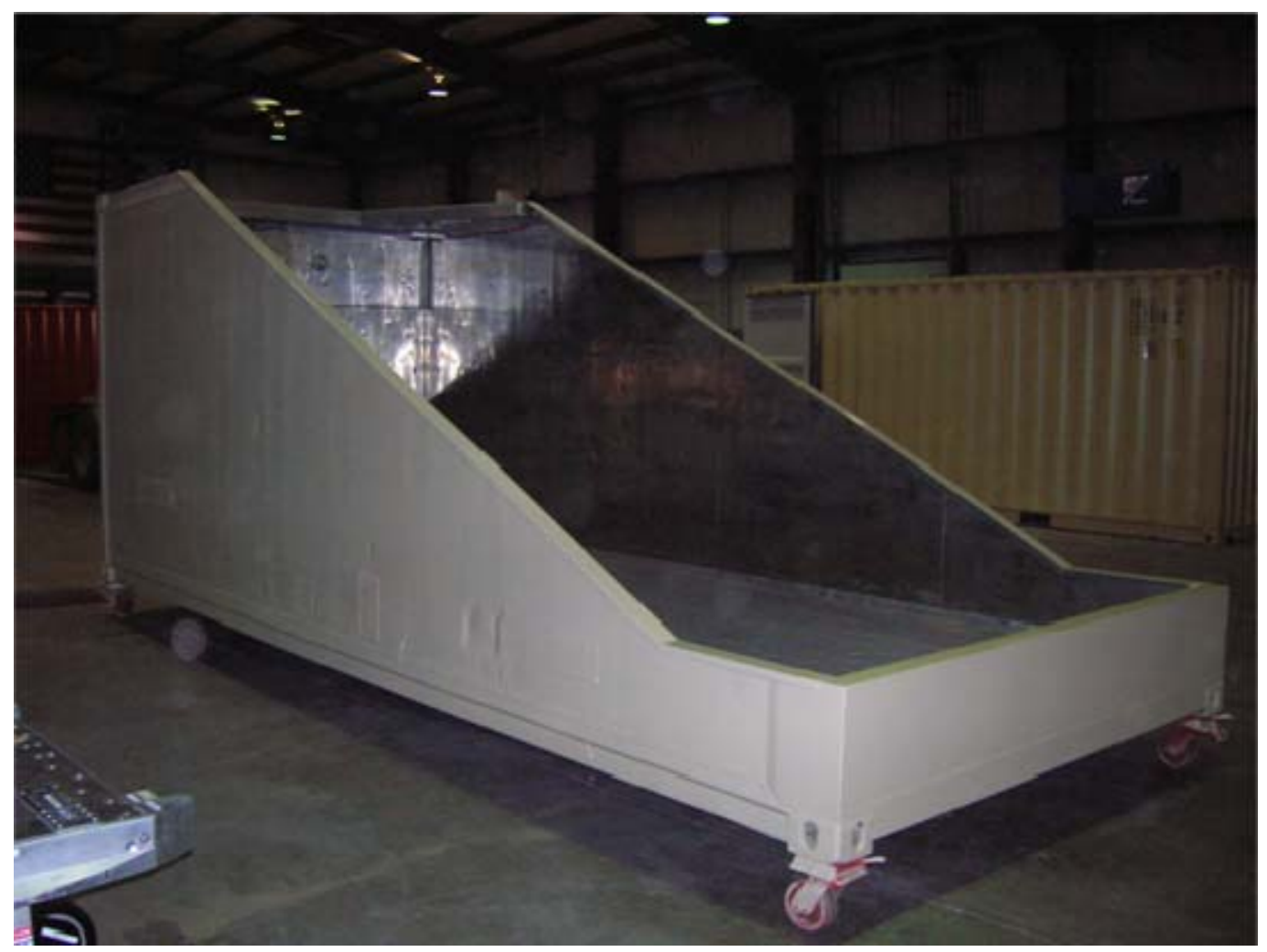

Figure 10. Completed field lysimeter prior to transport to the CAFB range.

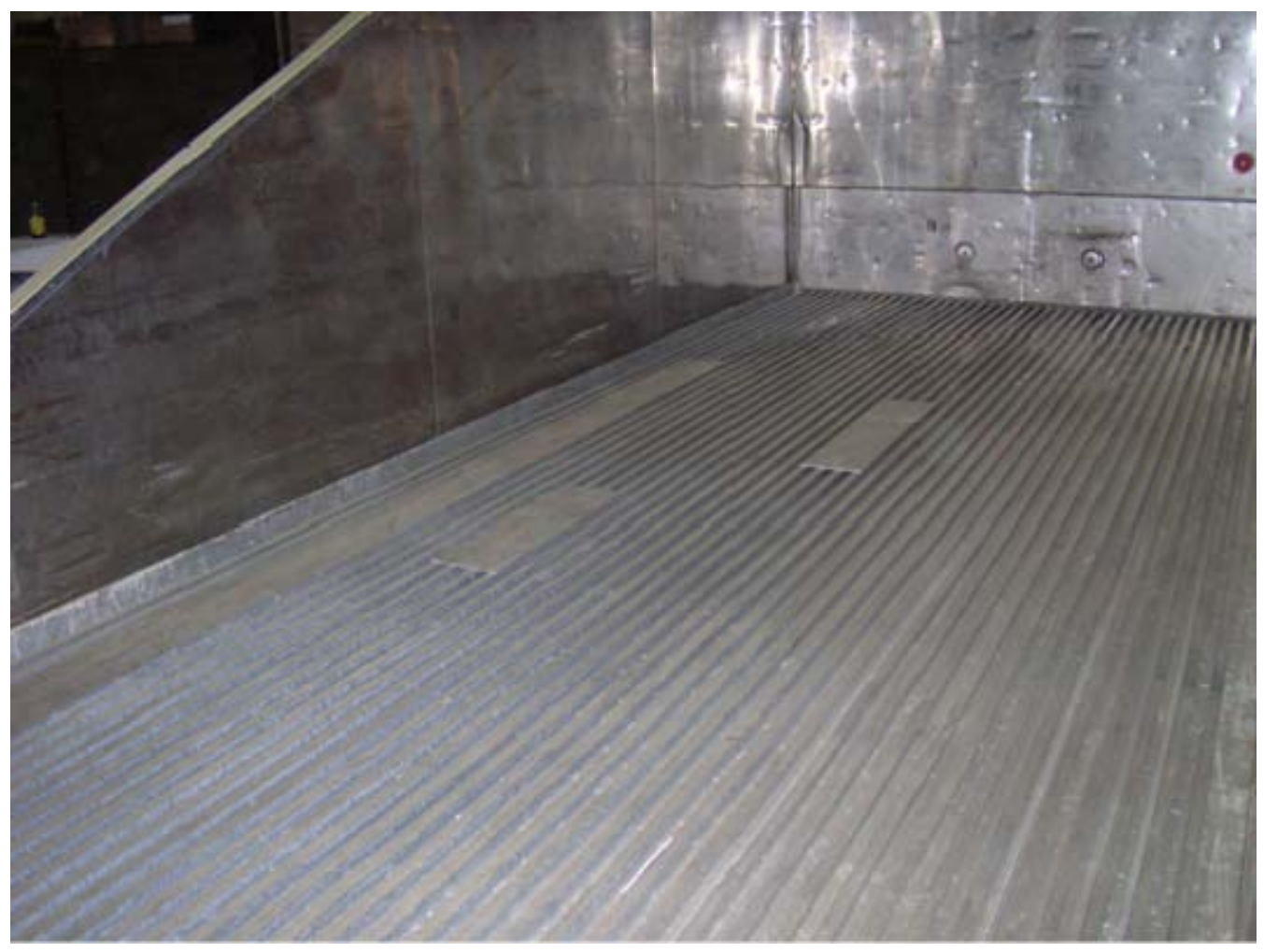

Figure 11. Interior view of the completed lysimeter demonstrating the ridged bottom to facilitate flow of the leachate from the amended ballistic sand. 


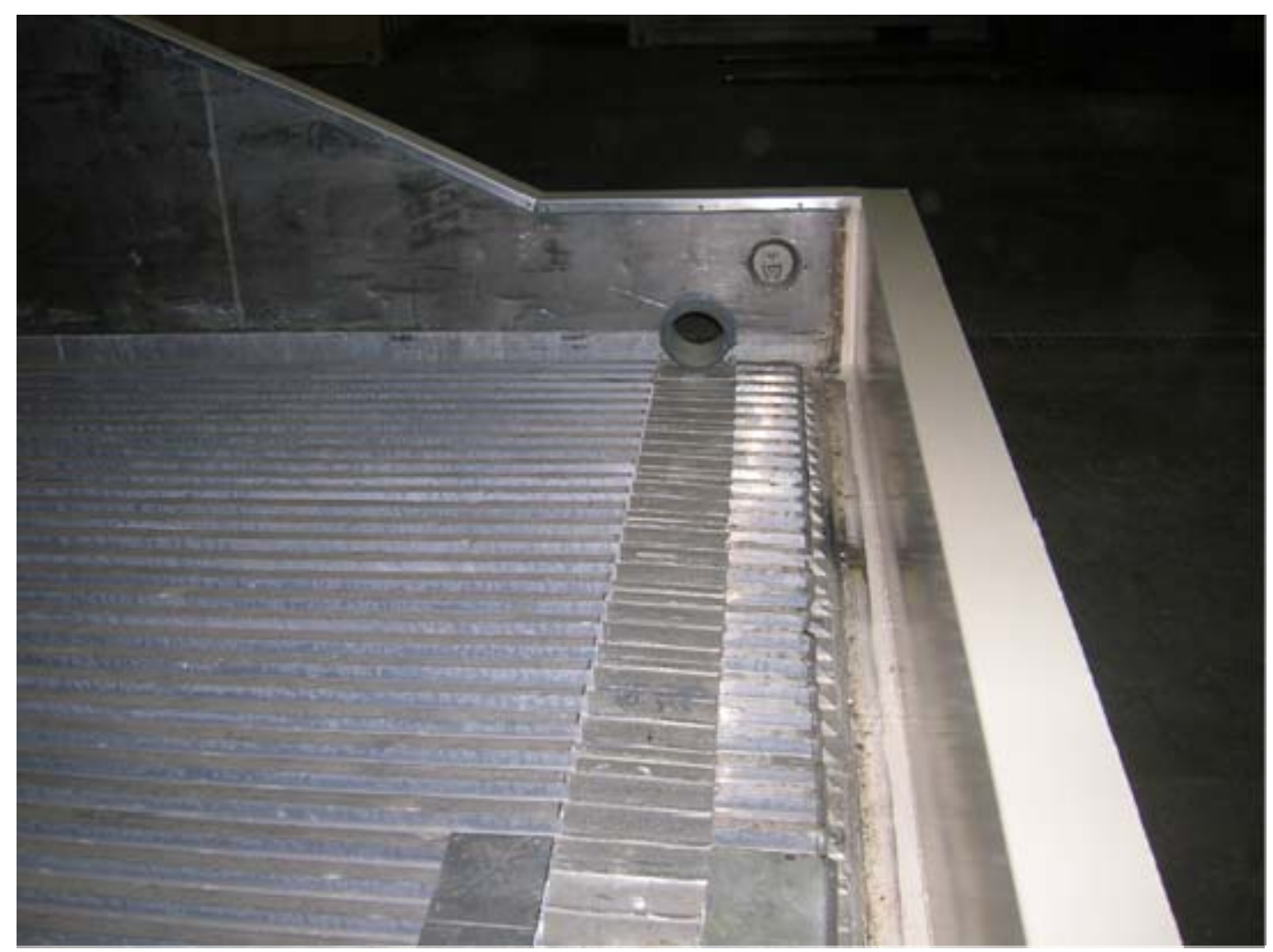

Figure 12. Interior view of the completed field lysimeter demonstrating the leachate collection system.

\section{Lysimeter Assembly at the CAFB Range}

The amendments used in the three lysimeters placed inside the impact berm of the M60 range are shown in Table 2.

Table 2. Amendment composition in the three field demonstration lysimeters.

\begin{tabular}{|l|l|l|}
\hline \multicolumn{3}{|c|}{ Lysimeter Location and Amendment Composition } \\
\hline Left Lysimeter & Center Lysimeter & Right Lysimeter \\
\hline $\begin{array}{l}\text { Washed ballistic sand mixed } \\
\text { with 5\% TRAPPS }\end{array}$ & $\begin{array}{l}\text { Washed ballistic sand mixed } \\
\text { with 5\% TRAPPS }\end{array}$ & Washed ballistic sand \\
\hline $\begin{array}{l}\text { 5\% TTF in a separate } \\
\text { container within the } \\
\text { Sand/TRAPPS }\end{array}$ & & \\
\hline
\end{tabular}

Detailed diagrams of the lysimeters and the leachate and surface water collection systems are provided in Figures 13, 14, and 15. 


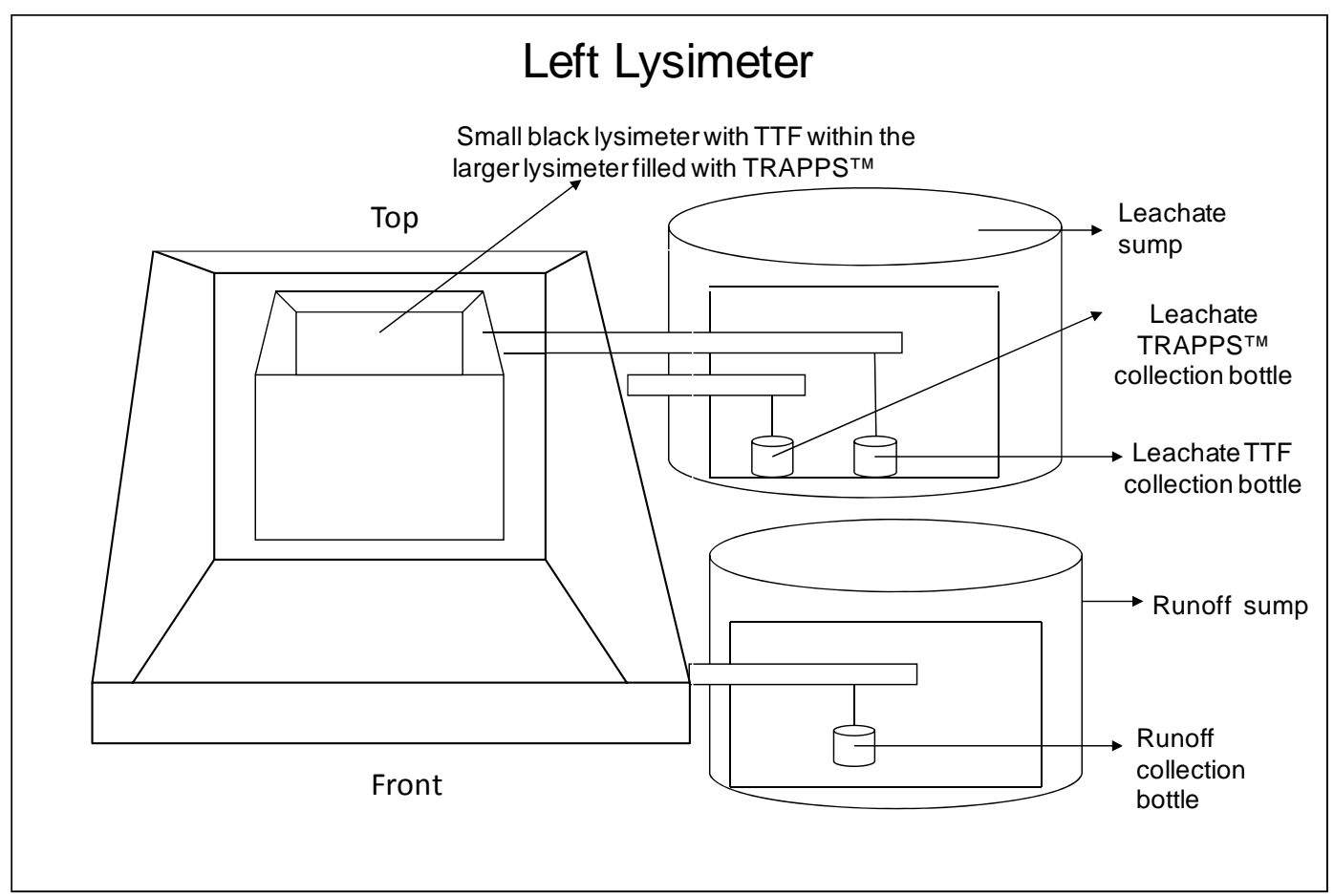

Figure 13. Assembly diagram of the left lysimeter showing arrangement of the leachate and runoff water collection systems.

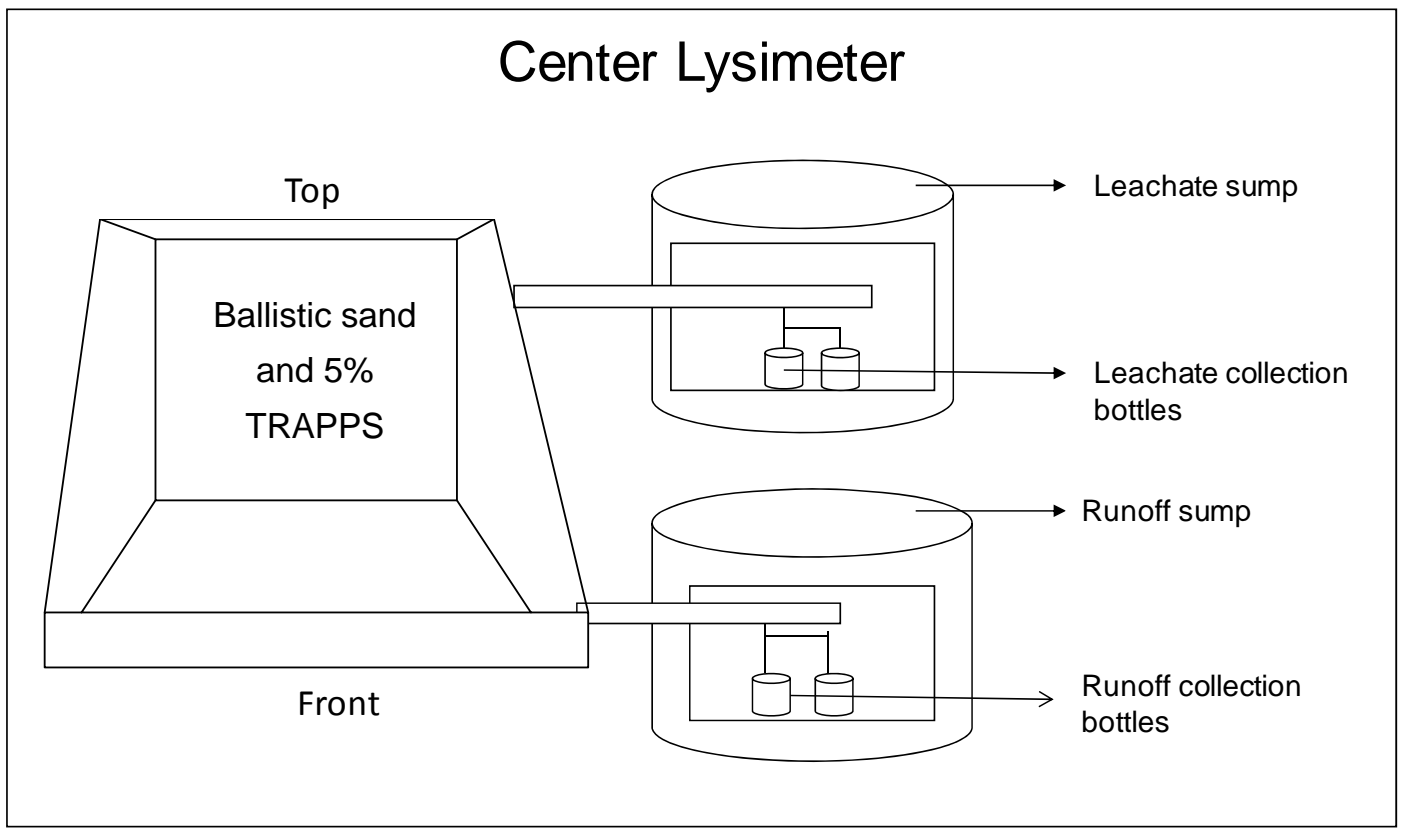

Figure 14. Assembly diagram of the center lysimeter showing arrangement of the leachate and runoff water collection systems. 


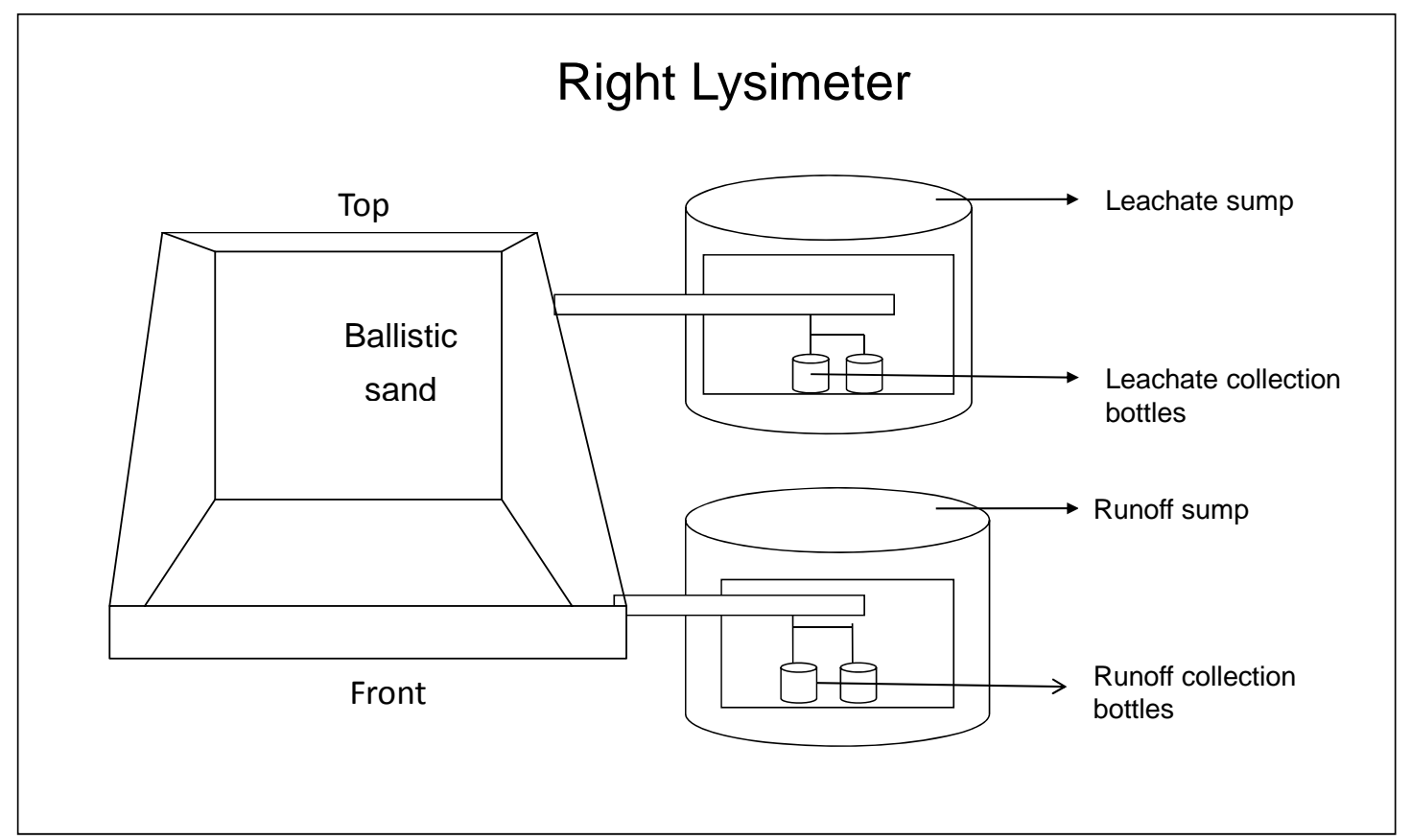

Figure 15. Assembly diagram of the right lysimeter showing arrangement of the leachate and runoff water collection systems.

Approximately 12 tons of sand and approximately $1 / 3^{\text {rd }}$ ton of amendment was used for construction of the M-60 PRBerm $^{\mathrm{TM}}$. Additional sand was used in construction of the plumbing systems and to stabilize the lysimeters, as specified in the design drawings. Additional stockpiled amendment was available to apply to the PRBerm ${ }^{\mathrm{TM}}$ should the sample analysis indicate that additional amendment was needed. A series of photographs (Figures 16, 17, 18 and 19) show the sequence of construction steps to install the three lysimeters in the impact berm in front of the firing positions of the M-60 range at the CAFB. The only operational maintenance required on the berm was occasional reshaping of the berm face to prevent formation of bullet pockets and exposure of the lysimeters.

\section{Sample Collection and Analysis}

\section{Berm Soil Samples}

Initial and final berm fill (i.e., sand) samples were collected to determine metal concentrations, TCLP and SPLP leaching concentrations, DDI suspend and settle concentrations, partition coefficient, and $\mathrm{pH}$. For the final soil sampling, bulk and dimensional samples were collected from each of the lysimeters. The lysimeter dimensional samples were based on the following measurements: 


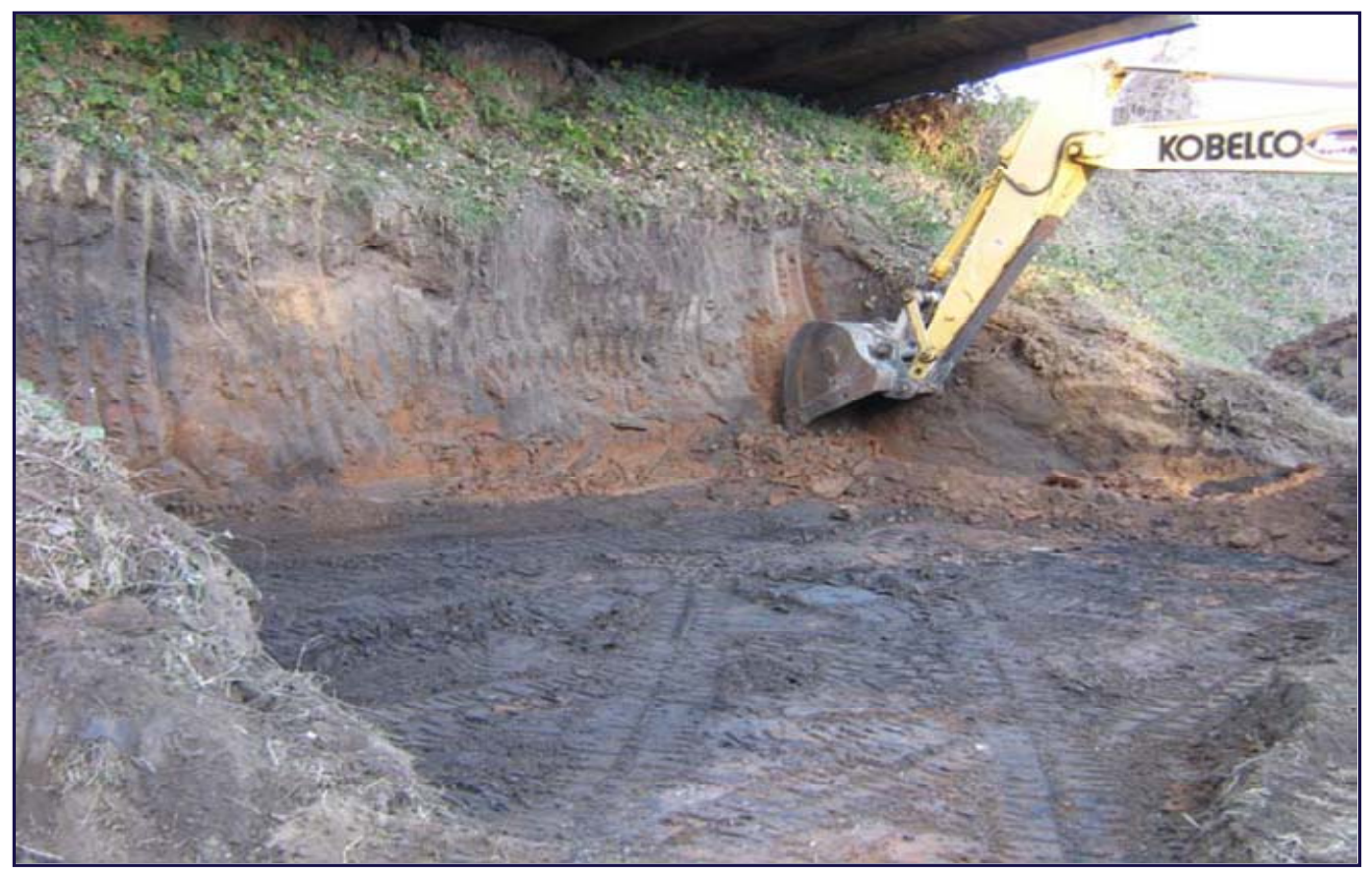

Figure 16. Removal of the old impact berm composed of local soil from under the newly constructed protective eyebrow.

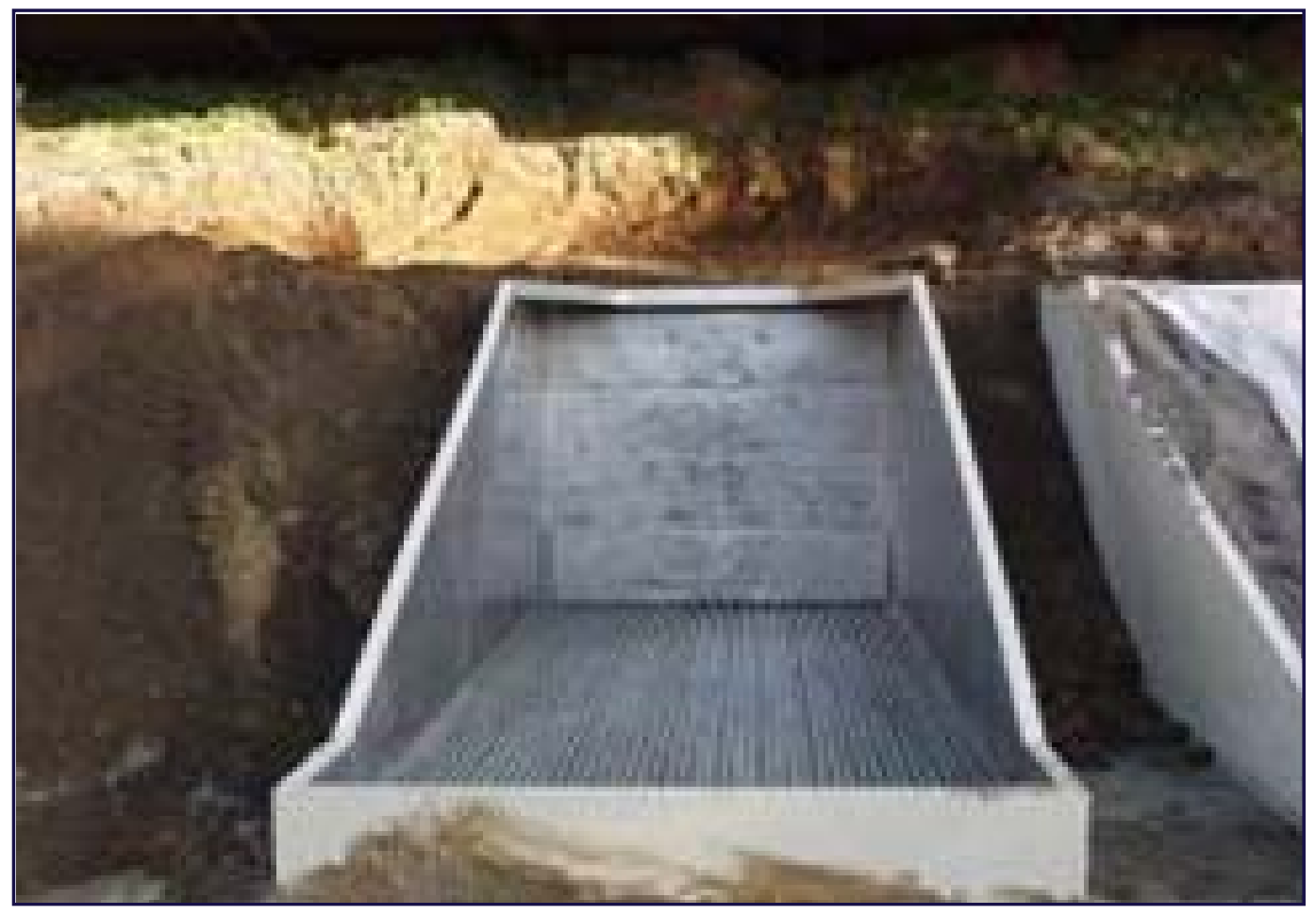

Figure 17. Placement of the three lysimeters in the impact berm in line with the three fixed firing positions. 


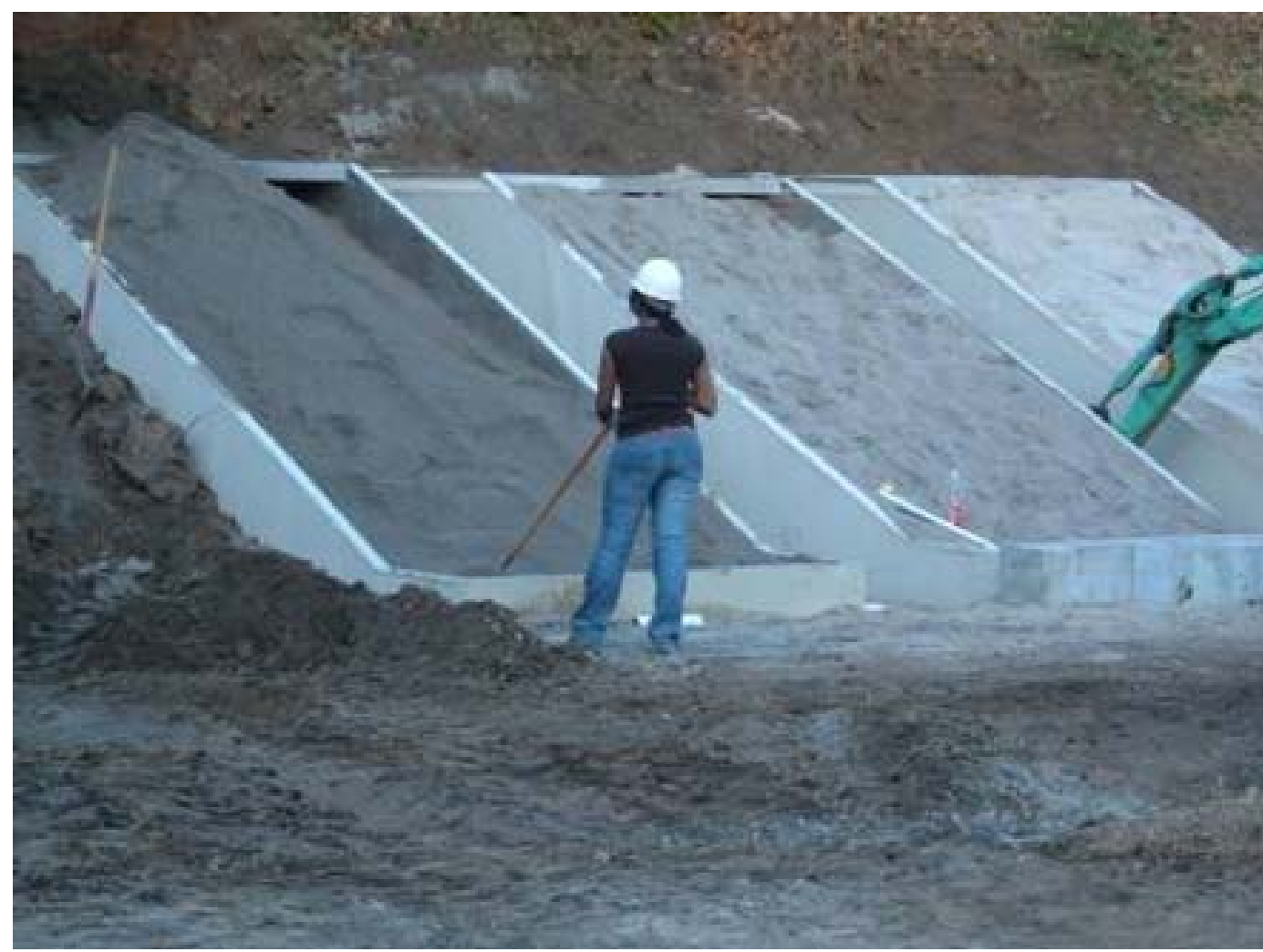

Figure 18. Placement of the amended ballistic sand in the lysimeters.

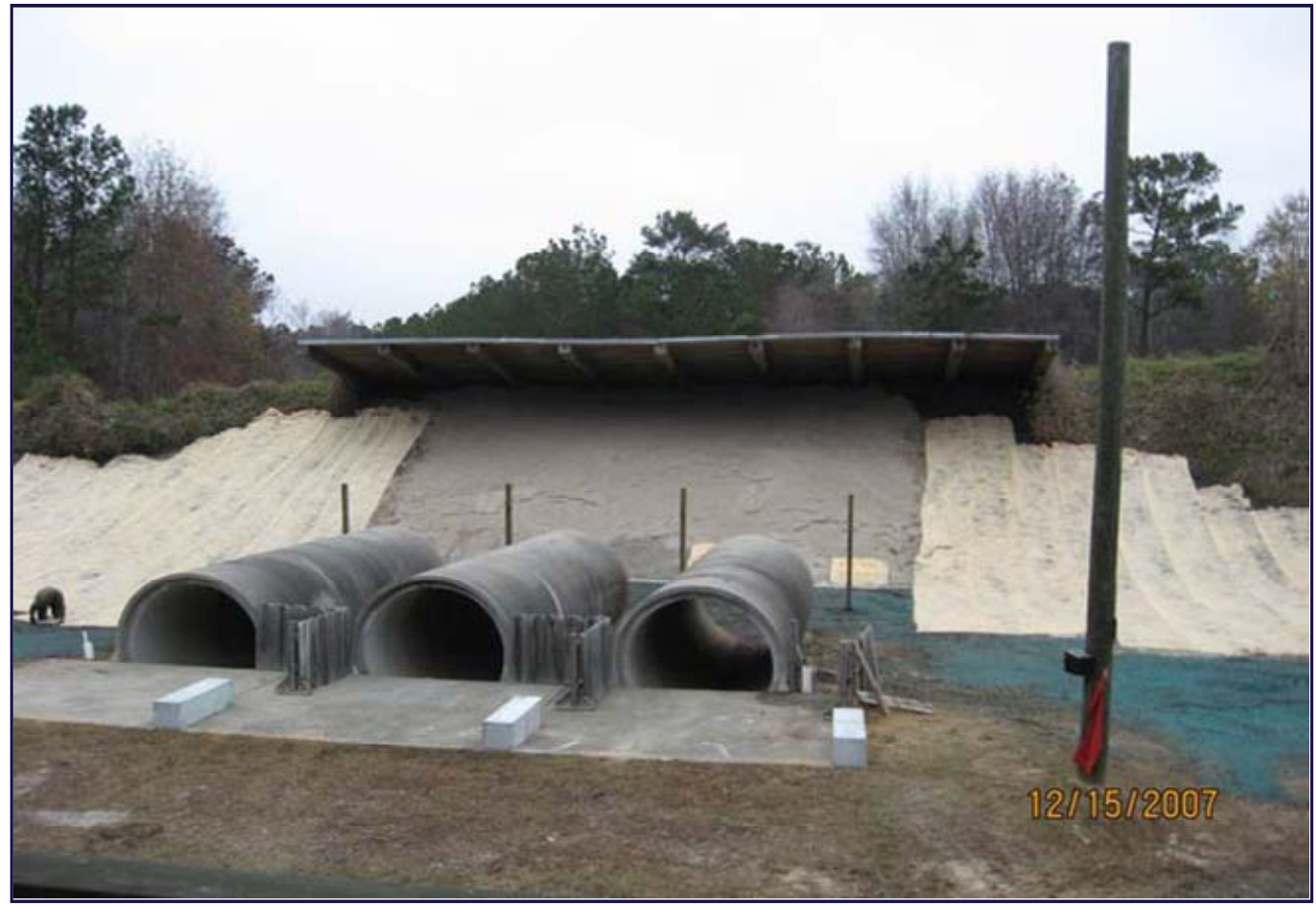

Figure 19. The completed impact berm enclosing the three experimental treatment lysimeters on the range, CAFB. 
1. $0-4$ feet $x 0-5$ feet

2. $0-4$ feet $x 5-10$ feet

3. $4-8$ feet $x 0-5$ feet

4. 4-8 feet $x$ 5-10 feet

These samples were taken with plastic cores 1-in. in diameter and 8-in. in length. Nine subsamples were collected and analyzed from each lysimeter. Triplicates analysis were performed on each of the nine subsamples.

Analyses for total metals in soils were performed using USEPA SW846 Method 3051 (1999a). The TCLP was performed on both bulk soil and the dimensional core samples using a 1:20 soil:solution ratio. The SPLP was performed only on the bulk soil samples using Extraction Fluid \#1 and a 1:20 soil:solution ratio. Toxicity Characteristic Leaching Procedure and SPLP samples were allowed to tumble on the tumbler for $18 \pm 2$ hours. After removal from the tumbler, samples were allowed to settle for about 30 minutes and filtrates were obtained using 0.45 micron filters attached to 10 $\mathrm{mL}$ syringes. The DDI Suspend and Settle Leaching Procedure (DDI S\&S) is a variation of the TCLP replacing the acid solution with DDI water. The DDI supend and settle test consitsted of an one (1) hour shake test and 18 hours settling time. After settling, samples were filtered using a $10 \mathrm{~mL}$ syringe with a 0.45 micron filter attached to $10 \mathrm{~mL}$ syringes. The $\mathrm{pH}$ was tested from the filtrates.

A 24-hour partition coefficient was performed on the pre-fired soils following procedures established in Appendix 6 of USEPA (1999b). The metals of interest for these soils were $\mathrm{Pb}, \mathrm{Cu}$, and $\mathrm{Fe}$. Stock solutions were prepared using Pb nitrate (CAS\#10099-74-8, Fisher Scientific), copper II sulfate pentahydrate (CAS\#7758-99-8, Sigma Aldrich) and ferrous sulfate (CAS\#7782-63-0, Sigma Aldrich).

A 1:10 soil to solution ratio was used for the 24 -hour test. Triplicate samples of 10 grams of soil per sample was weighed into each $125 \mathrm{~mL}$ nalgene bottle and $100 \mathrm{~mL}$ of each solution was added. Sample bottles were placed on the shaker for 24 hours, removed from the shaker, and allowed to settle for 10 minutes. Liquid samples were filtered using a 0.45 micron syringe filter attached to a $10 \mathrm{~mL}$ syringe and stored in the dark at $4{ }^{\circ} \mathrm{C}$ until analysis was conducted. 


\section{Aqueous Samples}

During the PRBerm ${ }^{\mathrm{TM}}$ field demonstration, stormwater runoff and leachate samples were collected bi-weekly using natural rain events. Samples were collected by the CAFB Bioenvironmental Engineering personnel under the general supervision of the ERDC-EL Principal Investigator (PI) or a Co-PI.

While flow-or time-averaged sampling may provide a better profile of runoff water quality over the storm event duration, there were logistical problems associated with collecting these samples. The proposed collection locations on the range could not use automated samplers because the equipment could not be located in areas that are in the line of fire. The equipment cannot be protected from being shot unless limits are placed on range use, which is not an option. As a result, manual grab samples were collected from sumps installed in the runoff flow path from each test cell on the berms and as part of the leachate collection system.

Water samples were collected in 1-L plastic bottles. The sampling collection point was then drained. Samples were preserved in accordance with EPA and ASTM preservation guidelines. Samples were properly labeled and tightly sealed to avoid cross contamination during storage and/ or shipment. Samples were packaged for shipment in rigid, insulated plastic ice chests. These samples were sent to ERDC-EL for analysis via overnight delivery.

Samples were analyzed in the laboratory for metals (total and dissolved) and TSS. Samples were field filtered using 0.45 micron filters prior to shipping for dissolved metals analysis in the laboratory.

\section{Methods}

The methods and procedures detailed in Table 3 were used for chemical and physical analysis of the PRBerm ${ }^{\mathrm{TM}}$ samples. Both liquid and samples were analyzed for heavy metals using an Inductively Coupled Plasma (ICP) Atomic Emission Spectroscopy (AES), with a reporting limit of 0.025 $\mathrm{mg} / \mathrm{L}$ for liquids and $5 \mathrm{mg} / \mathrm{kg}$ for soils (Perkin-Elmer Optima 4300 dual view, Perkin-Elmer, USA). 
Table 3. Summary of analysis methods and frequency.

\begin{tabular}{|c|c|c|}
\hline Contaminant/Parameter & Analytical Method & Analytical Frequency \\
\hline \multicolumn{3}{|c|}{ Aqueous Samples } \\
\hline Metals - total and dissolved & SW846-3015a & Bi-weekly \\
\hline Total suspended solids (TSS) & SM $2540 D^{b}$ & Bi-weekly \\
\hline $\mathrm{pH}$ & Electrode & Bi-weekly \\
\hline \multicolumn{3}{|c|}{ Soil Samples } \\
\hline Metals- total and dissolved & SW846-3051 & Initial and final \\
\hline $\mathrm{pH}$ & Electrode & Initial and final \\
\hline TCLP & SW846-1311 & Final \\
\hline SPLP & SW846-1312 & Final \\
\hline DDI S\&S & Modified SW846-1311 & Final \\
\hline$K_{d}$ & $\begin{array}{l}\text { 24-hr partition coefficient } \\
\text { test }^{c}\end{array}$ & Final \\
\hline
\end{tabular}

aUSEPA (1999a)

bAmerican Public Health Association (1998)

cUSEPA (1999b) 


\section{Results and Discussion}

\section{Rounds Fired}

Records were kept of the bullet type and number of rounds fired into the CAFB PRBerm ${ }^{\mathrm{TM}}$ to obtain an accurate account of the total $\mathrm{Pb}$ loading on the range. Background metals $(\mathrm{Pb})$ concentration in the washed ballistic sand was determined. The $\mathrm{Pb}$ loading on the three lysimeters is detailed in Table 4. The $7.62 \mathrm{~mm}$ round, used in the M-60 machine gun, and the $5.56 \mathrm{~mm}$ round, used in the M-16 rifle, were both fired on the CAFB range. The lysimeter amended with 5\% TRAPPS ${ }^{\mathrm{TM}}$ had the most $7.62 \mathrm{~mm}$ rounds fired into it and no $5.56 \mathrm{~mm}$ rounds fired into it. The smallest number of $7.62 \mathrm{~mm}$ rounds fired was 5,100, into both the control and 5\% $\mathrm{TRAPPS}^{\mathrm{TM}}+$ $5 \%$ TTF lysimeters. The control lysimeter had 2,400 total $5.56 \mathrm{~mm}$ rounds fired and the 5\% TRAPPS ${ }^{\mathrm{TM}}+5 \% \mathrm{TTF}$ had almost twice that number.

Table 4. Type and number of rounds fired into each lysimeter on the CAFB range during the field demonstration.

\begin{tabular}{|c|c|c|c|c|c|c|}
\hline \multirow[b]{2}{*}{ Date } & \multicolumn{3}{|c|}{ 7.62-mm rounds } & \multicolumn{3}{|c|}{ 5.56- $\mathrm{mm}$ rounds } \\
\hline & $\begin{array}{l}5 \% \\
\text { TRAPPS } \\
5 \% \text { TTF }\end{array}$ & \begin{tabular}{|l}
$5 \%$ \\
TRAPPS'M
\end{tabular} & Control & $\begin{array}{l}5 \% \\
\text { TRAPPS'M + } \\
5 \% \text { TTF }\end{array}$ & \begin{tabular}{|l}
$5 \%$ \\
TRAPPS'M
\end{tabular} & Control \\
\hline March 27 & 200 & 200 & 200 & 0 & 0 & 0 \\
\hline June 28 & 100 & 100 & 100 & 0 & 0 & 0 \\
\hline July 31 & 0 & 3,400 & 100 & 2,400 & 0 & 2,400 \\
\hline August 18 & 0 & 0 & 0 & 1,200 & 0 & 0 \\
\hline September 10 & 600 & 600 & 0 & 600 & 0 & 0 \\
\hline October 22 & 4,200 & 4,200 & 0 & 0 & 0 & 0 \\
\hline December 4 & 0 & 0 & 4,800 & 0 & 0 & 0 \\
\hline Total & 5,100 & 8,500 & 5,200 & 4,200 & 0 & 2,400 \\
\hline
\end{tabular}

\section{Aqueous Samples}

\section{Volumes Collected}

Volumes were taken biweekly. The total volume results are shown in Table 5. The control lysimeter had the greatest total effluent collected. The volume of leachate from the experimental lysimeters ranged from $51 \%$ to 
$63 \%$ of the total for the $5 \% \mathrm{TRAPPS}^{\mathrm{TM}}$ and the $5 \% \mathrm{TRAPPS}^{\mathrm{TM}}+5 \% \mathrm{TTF}$, respectively. The volume of runoff water from the experimental lysimeters ranged from $37 \%$ to $49 \%$ of the total volume for the $5 \%$ TRAPPS $^{\mathrm{TM}}+5 \% \mathrm{TTF}$ and the $5 \%$ TRAPPS $^{\mathrm{TM}}$, respectively. The most runoff was generated from the control lysimeter whereas the $5 \% \mathrm{TRAPPS}^{\mathrm{TM}}+5 \%$ TTF provided the most observed leachate.

Table 5. Volume of effluent collected from the PRBerm ${ }^{\mathrm{TM}}$ lysimeters during the field demonstration.

\begin{tabular}{|l|l|l|l|l|l|l|}
\hline Lysimeter & $\begin{array}{l}\text { Total } \\
\text { leachate } \\
\text { (L) }\end{array}$ & $\begin{array}{l}\text { Total } \\
\text { Runoff } \\
\text { (L) }\end{array}$ & $\begin{array}{l}\text { Total } \\
\text { effluent } \\
\text { (L) }\end{array}$ & $\begin{array}{l}\text { Leachate } \\
\text { (\% of total) }\end{array}$ & $\begin{array}{l}\text { Runoff } \\
\text { (\% of total) }\end{array}$ & $\begin{array}{l}\text { Ratio of } \\
\text { Leachate to } \\
\text { Runoff }\end{array}$ \\
\hline Control -Right & 23.02 & 36.11 & 59.13 & 39 & 61 & 0.64 \\
\hline $\begin{array}{l}5 \% \text { TRAPPS } \\
\text { Center }\end{array}$ & 21.94 & 20.68 & 42.62 & 51 & 49 & 1.06 \\
\hline $\begin{array}{l}5 \% \text { TRAPPSTM } \\
\text { - Left }\end{array}$ & 18.30 & a16.60 & 34.90 & 52 & 47 & 1.10 \\
\hline $\begin{array}{l}\text { 5\% TRAPPSTM } \\
+5 \% \text { TTF - } \\
\text { Left (insert) }\end{array}$ & 9.57 & a16.60 & 26.17 & 36 & 63 & 0.58 \\
\hline
\end{tabular}

aTotal runoff for $5 \%$ TRAPPSTM $^{\mathrm{T}}+5 \%$ TTF Left (insert) is the same as $5 \%$ TRAPPS $^{\text {TM }}$ - Left. There was only one runoff collection for both.

\section{pH}

The measured $\mathrm{pH}$ range was from 6.44 to 7.01 with detailed results reported in Figure 20. The unamended lysimeter had the lowest $\mathrm{pH}$ in both leachate and runoff water samples. The TTF leachate sample had the highest $\mathrm{pH}$ and the 5\% TRAPPS ${ }^{\text {тM }}+5 \%$ TTF sample had the lowest runoff $\mathrm{pH}$. Both amended and unamended lysimeters had acidic $\mathrm{pH}$ readings, except for the TTF leachate sample. It has been reported that inducing acidic conditions will promote the solubility of $\mathrm{Pb}$ compounds leading to effective $\mathrm{Pb}$ immobilization via formation of $\mathrm{Pb}$ pyromorphite (Yang et al. 2001).

The $\mathrm{pH}$ readings were taken for the pre- and post-firing demonstration soils (Table 6). There was a slight increase in the $\mathrm{pH}$ readings of the post-firing soils when compared to the pre-firing soils for all of the lysimeters. The preand post-firing soils yielded $\mathrm{pH}$ values that were slightly basic, except for the 5\% TRAPPS ${ }^{\mathrm{TM}}+5 \%$ TTF whose $\mathrm{pH}$ before firing was slightly below 7 . 


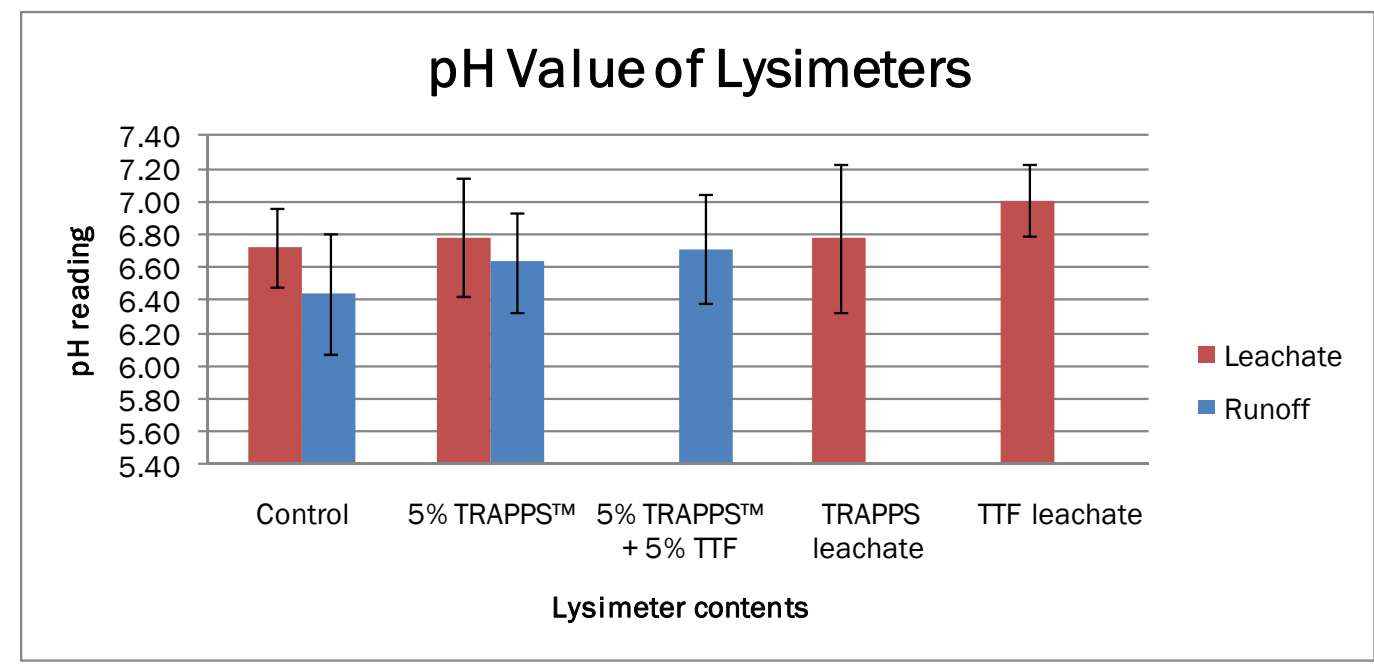

Figure 20. $\mathrm{pH}$ of lysimeter leachate and runoff water collected during the PRBerm ${ }^{\mathrm{TM}}$ field demonstration at the CAFB M60 range.

Table 6. Soil pH from control and experimental lysimeters pre- and post firing $(n=3)$.

\begin{tabular}{|c|c|c|c|c|}
\hline \multirow{2}{*}{\multicolumn{2}{|c|}{ Lysimeter }} & \multicolumn{3}{|c|}{$\mathrm{pH}$ values } \\
\hline & & \multirow{2}{*}{$\begin{array}{l}\text { Avg } \\
7.73\end{array}$} & \multirow{2}{*}{\begin{tabular}{|l|} 
Stdev \\
0.15
\end{tabular}} & \multirow{2}{*}{\begin{tabular}{|l|} 
\%Stdev \\
1.88
\end{tabular}} \\
\hline Control - Right & Pre-firing & & & \\
\hline & Post-firing & 8.06 & 0.03 & 0.33 \\
\hline \multirow[t]{2}{*}{$5 \%$ TRAPPS ${ }^{\top M}$ - Center } & Pre-firing & 7.29 & 0.03 & 0.42 \\
\hline & Post-firing & 7.48 & 0.14 & 1.90 \\
\hline \multirow[t]{2}{*}{$5 \%$ TRAPPS ${ }^{\text {TM }}$ - Left } & Pre-firing & 6.95 & 0.10 & 1.42 \\
\hline & Post-firing & 7.37 & 0.03 & 0.34 \\
\hline $\begin{array}{l}\text { 5\% TRAPPS'M }+5 \% \text { TTF - Left } \\
\text { (insert) }\end{array}$ & Post-firing & 7.09 & 0.06 & 0.78 \\
\hline
\end{tabular}

\section{Total Suspended Solids}

Suspended solids provide sorption surfaces and a route of transmission for many organic contaminants, heavy metals, and some soil nutrients. The TSS concentrations from the lysimeters varied depending on the amendment. Table 7 shows the average TSS concentration for both leachate and runoff from each of the lysimeters. The lysimeter that was amended with $5 \%$ TRAPPS $^{\mathrm{TM}}$ had the highest TSS concentration in both the leachate and runoff. High TSS has been correlated to higher concentrations of metals in the water. The $5 \%$ TRAPPS $^{\mathrm{TM}}$ lysimeter had the highest concentration of TSS in both leachate and runoff water at $4,000 \mathrm{mg} / \mathrm{L}$ and $545 \mathrm{mg} / \mathrm{L}$, respectively. However, the TSS values in the leachate were highly variable with a \% STDEV of $>300$. 
Table 7. Comparison of total suspended solids concentrations in leachate and runoff water collected during the PRBerm ${ }^{\mathrm{TM}}$ demonstration at the CAFB range.

\begin{tabular}{|c|c|c|c|c|c|c|c|}
\hline \multirow{3}{*}{\multicolumn{2}{|c|}{ Lysimeter }} & \multicolumn{6}{|c|}{ Total suspended solids (TSS) } \\
\hline & & \multicolumn{3}{|c|}{ Runoff Water (mg/L) } & \multicolumn{3}{|c|}{ Leachate (mg/L) } \\
\hline & & AVG & STEDV & \%STDEV & AVG & STEDV & \%STDEV \\
\hline \multirow{2}{*}{ Left } & $\begin{array}{l}5 \% \\
\text { TRAPPS }\end{array}$ & 161 & 319 & 199 & 412 & 713 & 173 \\
\hline & $\begin{array}{l}5 \% \\
\text { TRAPPSTM } \\
+5 \% \text { TTF }\end{array}$ & NA & NA & NA & 410 & 784 & 191 \\
\hline Center & \begin{tabular}{|l}
$5 \%$ \\
TRAPPSTM
\end{tabular} & 545 & 850 & 156 & 4,176 & 13,427 & 322 \\
\hline Right & Control & 120 & 242 & 202 & 62 & 57 & 91 \\
\hline
\end{tabular}

NA = not applicable

\section{Total Metals}

Total (digested) metals varied over a wide range of concentrations in runoff water and leachate from the lysimeters. Table 8 shows the average concentration of total metals in the leachate. The leachate concentration for all metals were high from the $5 \%$ TRAPPS $^{\mathrm{TM}}$ lysimeter when compared to the other experimental lysimeters. The $\mathrm{Pb}$ leachate concentrations ranged from $0.08 \mathrm{mg} / \mathrm{L}$ (control lysimeter) to $50 \mathrm{mg} / \mathrm{L}$ (5\% TRAPPS $^{\mathrm{TM}}$ lysimeter).

Table 8. Average concentration of total (digested) metals in lysimeter leachate $(\mathrm{mg} / \mathrm{L}, \mathrm{n}=3)$.

\begin{tabular}{|l|l|l|l|l|l|l|l|l|}
\hline \multirow{2}{*}{ Metal } & \multicolumn{9}{|c|}{ Lysimeter } \\
\cline { 2 - 9 } & \multicolumn{2}{|c|}{ Control } & \multicolumn{2}{c|}{ 5\% TRAPPSTM } & \multicolumn{2}{c|}{ Left 5\% TRAPPS } & \multicolumn{2}{c|}{ Left 5\% TTF } \\
\cline { 2 - 9 } & AVG* & STDEV & AVG & STDEV & AVG & STDEV & AVG & STDEV \\
\hline $\mathrm{Pb}$ & 0.08 & 0.16 & 50.13 & 178.40 & 7.89 & 18.82 & 6.35 & 13.25 \\
\hline $\mathrm{Cr}$ & 0.03 & 0.00 & 0.09 & 0.16 & 0.03 & 0.01 & 0.03 & 0.01 \\
\hline $\mathrm{Cu}$ & 0.13 & 0.22 & 32.74 & 100.07 & 4.75 & 17.42 & 1.31 & 2.58 \\
\hline $\mathrm{Ni}$ & 0.02 & 0.00 & 0.08 & 0.13 & 0.03 & 0.01 & 0.03 & 0.01 \\
\hline $\mathrm{Zn}$ & 0.05 & 0.05 & 11.03 & 31.05 & 0.28 & 0.49 & 0.22 & 0.35 \\
\hline $\mathrm{Fe}$ & 0.51 & 0.52 & 30.51 & 89.46 & 4.84 & 9.66 & 4.20 & 6.38 \\
\hline $\mathrm{Mn}$ & 0.03 & 0.01 & 0.32 & 0.82 & 0.06 & 0.08 & 0.06 & 0.07 \\
\hline $\mathrm{Sb}$ & 0.21 & 0.31 & 2.26 & 5.66 & 0.20 & 0.36 & 0.16 & 0.27 \\
\hline $\mathrm{P} * *$ & 5.00 & 0.00 & 70.90 & 40.01 & 40.52 & 26.96 & 38.55 & 17.45 \\
\hline
\end{tabular}

*Averages and standard deviations are calculated based on a detection limit of $0.025 \mathrm{mg} / \mathrm{L}$ for all metals except for $P$.

** The detection limit for $\mathrm{P}$ is $5.00 \mathrm{mg} / \mathrm{L}$. 
The concentrations of total (digested) metals in the runoff water (Table 9) were less in the Left 5\% TRAPPS ${ }^{\mathrm{TM}}+5 \%$ TTF compared to the $5 \%$ TRAPPS $^{\mathrm{TM}}$ lysimeter for all metals. The 5\% TRAPPS $^{\mathrm{TM}}$ lysimeter had the highest concentration of total metals in the runoff water of all the experimental lysimeters.

Table 9. Average concentration of total (digested) metals in lysimeter runoff water $(\mathrm{mg} / \mathrm{L}, \mathrm{n}=3)$.

\begin{tabular}{|c|c|c|c|c|c|c|}
\hline \multirow[b]{3}{*}{ Metal } & \multicolumn{6}{|c|}{ Lysimeter } \\
\hline & \multicolumn{2}{|c|}{ Control } & \multicolumn{2}{|c|}{$5 \%$ TRAPPS $^{\mathrm{TM}}$} & \multicolumn{2}{|c|}{$5 \%$ TRAPPS $^{\mathrm{TM}}+5 \%$ TTF } \\
\hline & AVG* & STDEV & AVG & STDEV & AVG & STDEV \\
\hline $\mathrm{Pb}$ & 0.62 & 1.07 & 9.78 & 19.48 & 2.34 & 5.20 \\
\hline $\mathrm{Cr}$ & 0.04 & 0.01 & 0.05 & 0.02 & 0.03 & 0.00 \\
\hline $\mathrm{Cu}$ & 0.42 & 0.55 & 2.09 & 3.67 & 0.54 & 0.92 \\
\hline $\mathrm{Ni}$ & 0.04 & 0.02 & 0.05 & 0.01 & 0.03 & 0.00 \\
\hline $\mathrm{Zn}$ & 0.04 & 0.02 & 0.05 & 0.01 & 0.03 & 0.00 \\
\hline $\mathrm{Fe}$ & 0.83 & 0.99 & 7.82 & 14.77 & 2.46 & 4.08 \\
\hline $\mathrm{Mn}$ & 0.04 & 0.01 & 0.10 & 0.12 & 0.10 & 0.23 \\
\hline $\mathrm{Sb}$ & 0.44 & 1.03 & 0.50 & 0.96 & 0.30 & 0.41 \\
\hline $\mathrm{P} * *$ & 8.23 & 3.04 & 15.81 & 15.23 & 7.62 & 8.80 \\
\hline
\end{tabular}

*Averages and standard deviations are calculated based on a detection limit of $0.025 \mathrm{mg} / \mathrm{L}$ for all metals except for $P$.

**The detection limit for $\mathrm{P}$ is $5.00 \mathrm{mg} / \mathrm{L}$.

\section{Soluble Metals}

The average concentrations of soluble metals in the lysimeter leachate are shown in Table 10. The metal with the highest leachate concentration in all the lysimeters, excluding $\mathrm{P}$, was $\mathrm{Sb}$. The 5\% TRAPPS $^{\mathrm{TM}}$ lysimeter had $74.09 \mathrm{mg} / \mathrm{L}$ of $\mathrm{P}$ compared to the unamended control lysimeter which had $5.00 \mathrm{mg} / \mathrm{L}$ of $\mathrm{P}$.

The soluble $\mathrm{Pb}, \mathrm{Cr}, \mathrm{Cu}, \mathrm{Zn}$, and $\mathrm{Fe}$ concentrations in the runoff water decreased in both amended lysimeters when compared to the control (Table 11). The soluble $\mathrm{Pb}$ concentration in the control runoff water was $0.18 \mathrm{mg} / \mathrm{L}, 7.62 \mathrm{~mm}$ was $0.15 \mathrm{mg} / \mathrm{L}$, and the Left 5\% TRAPPS $^{\mathrm{TM}}$ was $0.06 \mathrm{mg} / \mathrm{L}$. When compared to the 5\% TRAPPS ${ }^{\mathrm{TM}}$ lysimeter, the Left 5\% TRAPPS $^{\mathrm{TM}}$ lysimeter showed the greatest reduction for the soluble $\mathrm{Pb}, \mathrm{Cu}$, $\mathrm{Ni}$, and $\mathrm{Sb}$. The Fe concentration in the 5\% TRAPPS $^{\mathrm{TM}}$ lysimeter runoff water was decreased compared to the Left 5\% TRAPPS ${ }^{\mathrm{TM}}$. 
Table 10. Average concentration of soluble metals in lysimeter leachate $(\mathrm{mg} / \mathrm{L}, \mathrm{n}=3)$.

\begin{tabular}{|l|l|l|l|l|l|l|l|l|}
\hline \multirow{2}{*}{ Metal } & \multicolumn{7}{|c|}{ Lysimeter } \\
\cline { 2 - 9 } & \multicolumn{2}{|c|}{ Control } & \multicolumn{2}{c|}{$5 \%$ TRAPPS } & \multicolumn{2}{c|}{ Left 5\% TRAPPSTM } & \multicolumn{2}{c|}{ Left 5\% TTF } \\
\cline { 2 - 9 } & AVG* & STDEV & AVG & STDEV & AVG & STDEV & AVG & STDEV \\
\hline $\mathrm{Pb}$ & 0.03 & 0.01 & 0.11 & 0.28 & 0.03 & 0.02 & 0.03 & 0.01 \\
\hline $\mathrm{Cr}$ & 0.03 & 0.00 & 0.04 & 0.01 & 0.03 & 0.00 & 0.03 & 0.00 \\
\hline $\mathrm{Cu}$ & 0.03 & 0.02 & 0.09 & 0.08 & 0.03 & 0.00 & 0.03 & 0.00 \\
\hline $\mathrm{Ni}$ & 0.03 & 0.00 & 004 & 0.01 & 0.03 & 0.00 & 0.03 & 0.00 \\
\hline $\mathrm{Zn}$ & 0.03 & 0.01 & 0.03 & 0.00 & 0.03 & 0.02 & 0.06 & 0.13 \\
\hline $\mathrm{Fe}$ & 0.04 & 0.03 & 0.06 & 0.05 & 0.03 & 0.00 & 0.03 & 0.07 \\
\hline $\mathrm{Mn}$ & 0.03 & 0.00 & 0.05 & 0.01 & 0.03 & 0.00 & 0.03 & 0.00 \\
\hline $\mathrm{Sb}$ & 0.30 & 0.39 & 0.65 & 1.51 & 0.13 & 0.18 & 0.09 & 0.12 \\
\hline $\mathrm{P} * *$ & 5.00 & 0.00 & 74.09 & 48.32 & 40.13 & 31.06 & 38.85 & 20.00 \\
\hline
\end{tabular}

*Averages and standard deviations are calculated based on a detection limit of $0.025 \mathrm{mg} / \mathrm{L}$ for all metals except for $P$.

** The detection limit for $\mathrm{P}$ is $5.00 \mathrm{mg} / \mathrm{L}$.

Table 11. Average concentration of soluble metals in lysimeter runoff water $(\mathrm{mg} / \mathrm{L}, \mathrm{n}=3)$.

\begin{tabular}{|c|c|c|c|c|c|c|}
\hline \multirow[b]{3}{*}{ Metal } & \multicolumn{6}{|c|}{ Lysimeter } \\
\hline & \multicolumn{2}{|c|}{ Control } & \multicolumn{2}{|c|}{ 5\% TRAPPS ${ }^{\mathrm{TM}}$} & \multicolumn{2}{|c|}{$5 \%$ TRAPPS ${ }^{\mathrm{TM}}+5 \%$ TTF } \\
\hline & AVG* & STDEV & AVG & STDEV & AVG & STDEV \\
\hline $\mathrm{Pb}$ & 0.18 & 0.29 & 0.15 & 0.32 & 0.06 & 0.08 \\
\hline $\mathrm{Cr}$ & 0.04 & 0.01 & 0.03 & 0.01 & 0.03 & 0.00 \\
\hline $\mathrm{Cu}$ & 0.24 & 0.38 & 0.23 & 0.30 & 0.08 & 0.10 \\
\hline $\mathrm{Ni}$ & 0.04 & 0.01 & 0.05 & 0.01 & 0.03 & 0.00 \\
\hline $\mathrm{Zn}$ & 0.04 & 0.01 & 0.03 & 0.01 & 0.03 & 0.00 \\
\hline $\mathrm{Fe}$ & 0.30 & 0.36 & 0.15 & 0.17 & 0.25 & 0.51 \\
\hline $\mathrm{Mn}$ & 0.04 & 0.01 & 0.04 & 0.01 & 0.04 & 0.07 \\
\hline $\mathrm{Sb}$ & 0.38 & 0.71 & 0.53 & 0.92 & 0.37 & 0.50 \\
\hline $\mathrm{P} * *$ & 8.33 & 2.71 & 9.83 & 3.92 & 5.32 & 1.05 \\
\hline
\end{tabular}

*Averages and standard deviations are calculated based on a detection limit of $0.025 \mathrm{mg} / \mathrm{L}$ for all metals except for $P$.

** The detection limit for $\mathrm{P}$ is $5.00 \mathrm{mg} / \mathrm{L}$. 


\section{Pb for soils, leachates, and runoffs}

Calculations were based on the number of rounds fired multiplied by the metal content in each of the two rounds (Tables 12 and 13). The mass of the soil was the same in each of the lysimeters. The number of rounds varied per lysimeter. The control and the 5\% TRAPPS ${ }^{\mathrm{TM}}+5 \%$ TTF both had the same amount of $7.62 \mathrm{~mm}$ rounds fired so the $\mathrm{Pb}, \mathrm{Cu}, \mathrm{Zn}, \mathrm{Fe}, \mathrm{Mg}$, and $\mathrm{Sb}$ masses were the same. The 5\%TRAPPS ${ }^{\mathrm{TM}}$ lysimeter had the most metal mass present for all metals for the $7.62 \mathrm{~mm}$ rounds. No $5.56 \mathrm{~mm}$ rounds were fired in the 5\%TRAPPS ${ }^{\mathrm{TM}}$ lysimeter as shown in Table 13. The 5\% TRAPPS $^{\mathrm{TM}}+5 \%$ TTF had the most metal mass content for the $5.56 \mathrm{~mm}$ round. Table 14 shows the total metal concentrations for both the $7.62 \mathrm{~mm}$ and $5.56 \mathrm{~mm}$ rounds. The highest $\mathrm{Pb}$ concentration was present in the 5\%TRAPPS ${ }^{\mathrm{TM}}$ lysimeter. The untreated lysimeter (Control) had the least amount of $\mathrm{Pb}$ present in the sand.

The control lysimeter had the highest $\mathrm{Pb}$ concentration in the soluble runoff (Table 15), but the $7.62 \mathrm{~mm}$ lysimeter had the highest $\mathrm{Pb}$ concentration in the soil. Surface runoff transports soil particles containing adsorbed lead; this runoff assists in the migration and subsequent desorption of lead from contaminated soils. The mobility of dissolved $\mathrm{Pb}$ in the runoff may be due in part to the enhanced solubilization of organo- $\mathrm{Pb}$ when organic matter is present in the soil. Zhou and Wong (2001) states that dissolved organic carbon may enhance metal transport, especially in calcareous soil by acting as a carrier through the formation of soluble organo-metal complexes. It is estimated that these mobile, organically complexed forms of $\mathrm{Pb}$ could account for large cumulative losses of $\mathrm{Pb}$ from the soil (McBride et al. 1997). The high content of $\mathrm{P}$ in the 5\% TRAPPS ${ }^{\mathrm{TM}}+5 \%$ TTF lysimeter soil reduced the filtered $\mathrm{Pb}$ in the runoff samples through the formation of lead phosphates. Previous work has been completed by (Santillian-Medrano et al. 1975) suggesting that lead pyromorphite is the primary mineral controlling $\mathrm{Pb}$ solubility in soils amended with various forms of phosphates.

\section{Berm Soil Samples}

\section{pH}

For the pre- and post-demonstration soils $\mathrm{pH}$ readings were taken. Table 16 shows that there was an increase in the $\mathrm{pH}$ readings of the post-demonstration soils when compared to the pre-demonstration soils for all of the lysimeters. The pre-and post-demonstration soils yielded $\mathrm{pH}$ values that were in the neutral to alkaline range except for the 5\% $\mathrm{TRAPPS}^{\mathrm{TM}}+5 \% \mathrm{TTF}$ whose $\mathrm{pH}$ before firing was slightly below 7 . 
Table 12. Calculations based on $7.62 \mathrm{~mm}$ round.

\begin{tabular}{|c|c|c|c|c|c|c|c|c|c|c|c|}
\hline \multirow[b]{2}{*}{ Metal } & \multirow[b]{2}{*}{$\begin{array}{l}\text { Metal } \\
\text { Mass } \\
\text { per } \\
\text { Round, g }\end{array}$} & \multirow[b]{2}{*}{$\begin{array}{l}\text { Mass } \\
\text { of } \\
\text { Sand, } \\
\mathrm{kg}\end{array}$} & \multicolumn{3}{|c|}{ Control } & \multicolumn{3}{|c|}{ *7.62 mm } & \multicolumn{3}{|c|}{$5 \%$ TRAPPS $^{\mathrm{TM}}+5 \%$ TTF } \\
\hline & & & $\begin{array}{l}\text { Number } \\
\text { of } \\
\text { Bullets } \\
\text { Fired }\end{array}$ & $\begin{array}{l}\text { Mass per } \\
\text { Total } \\
\text { Rounds } \\
\text { Fired, g }\end{array}$ & $\begin{array}{l}\text { Conc. in } \\
\text { Sand, } \\
\text { mg/kg }\end{array}$ & $\begin{array}{l}\text { Number } \\
\text { of } \\
\text { Bullets } \\
\text { Fired }\end{array}$ & $\begin{array}{l}\text { Mass per } \\
\text { Total } \\
\text { Rounds } \\
\text { Fired, g }\end{array}$ & $\begin{array}{l}\text { Conc. in } \\
\text { Sand, } \\
\mathrm{mg} / \mathrm{kg}\end{array}$ & $\begin{array}{l}\text { Number } \\
\text { of } \\
\text { Bullets } \\
\text { Fired }\end{array}$ & $\begin{array}{l}\text { Mass per } \\
\text { Total } \\
\text { Rounds } \\
\text { Fired, g }\end{array}$ & $\begin{array}{l}\text { Conc. in } \\
\text { Sand, } \\
\text { mg/kg }\end{array}$ \\
\hline $\mathrm{Pb}$ & 4.9982 & \multirow{7}{*}{19583} & \multirow{7}{*}{5100} & 25490.61 & 1301.63 & \multirow{7}{*}{8500} & 42484.35 & 2169.38 & \multirow{7}{*}{5100} & 25490.61 & 1301.63 \\
\hline $\mathrm{Cu}$ & 2.8105 & & & 14333.58 & 731.92 & & 23889.30 & 1219.86 & & 14333.58 & 731.92 \\
\hline $\mathrm{Zn}$ & 0.3091 & & & 1576.48 & 80.50 & & 2627.47 & 13417 & & 1576.48 & 80.50 \\
\hline $\mathrm{Fe}$ & 1.5473 & & & 7891.10 & 402.94 & & 13151.84 & 671.57 & & 7891.10 & 402.94 \\
\hline $\mathrm{Mg}$ & 0.0019 & & & 9.69 & 0.49 & & 16.15 & 0.82 & & 9.69 & 0.49 \\
\hline $\mathrm{Sb}$ & 0.0504 & & & 257.04 & 13.13 & & 428.40 & 21.88 & & 257.04 & 13.13 \\
\hline $\begin{array}{l}\text { Other } \\
\text { metals }\end{array}$ & 0.0326 & & & 166.26 & 8.49 & & 277.10 & 14.15 & & 166.26 & 8.49 \\
\hline
\end{tabular}

Table 13. Calculations based on $5.56 \mathrm{~mm}$ round.

\begin{tabular}{|c|c|c|c|c|c|c|c|c|c|c|c|}
\hline \multirow[b]{2}{*}{ Metal } & \multirow[b]{2}{*}{$\begin{array}{l}\text { Metal } \\
\text { Mass per } \\
\text { Round, g }\end{array}$} & \multirow[b]{2}{*}{$\begin{array}{l}\text { Mass } \\
\text { of } \\
\text { Sand, } \\
\mathrm{kg}\end{array}$} & \multicolumn{3}{|c|}{ Control } & \multicolumn{3}{|c|}{$7.62 \mathrm{~mm}$} & \multicolumn{3}{|c|}{$5 \%$ TRAPPS ${ }^{\text {TM }}+5 \%$ TTF } \\
\hline & & & $\begin{array}{l}\text { Number } \\
\text { of } \\
\text { Bullets } \\
\text { Fired }\end{array}$ & $\begin{array}{l}\text { Mass per } \\
\text { Total } \\
\text { Rounds } \\
\text { Fired, g }\end{array}$ & $\begin{array}{l}\text { Conc. in } \\
\text { Sand, } \\
\mathrm{mg} / \mathrm{kg}\end{array}$ & $\begin{array}{l}\text { Number } \\
\text { of } \\
\text { Bullets } \\
\text { Fired }\end{array}$ & $\begin{array}{l}\text { Mass } \\
\text { per Total } \\
\text { Rounds } \\
\text { Fired, g }\end{array}$ & $\begin{array}{l}\text { Conc. } \\
\text { in } \\
\text { Sand, } \\
\mathrm{mg} / \mathrm{kg}\end{array}$ & $\begin{array}{l}\text { Number } \\
\text { of } \\
\text { Bullets } \\
\text { Fired }\end{array}$ & $\begin{array}{l}\text { Mass per } \\
\text { Total } \\
\text { Rounds } \\
\text { Fired, g }\end{array}$ & $\begin{array}{l}\text { Conc. in } \\
\text { Sand, } \\
\mathrm{mg} / \mathrm{kg}\end{array}$ \\
\hline $\mathrm{Pb}$ & 4.9982 & \multirow{7}{*}{19583} & \multirow{7}{*}{2400} & 4928.40 & 251.66 & \multirow{7}{*}{0} & 0.00 & 0.00 & \multirow{7}{*}{4200} & 8624.70 & 440.40 \\
\hline $\mathrm{Cu}$ & 2.8105 & & & 2771.28 & 141.51 & & 0.00 & 0.00 & & 4849.74 & 247.64 \\
\hline $\mathrm{Zn}$ & 0.3091 & & & 304.80 & 15.56 & & 0.00 & 0.00 & & 533.40 & 27.24 \\
\hline $\mathrm{Fe}$ & 1.5473 & & & 1525.68 & 77.91 & & 0.00 & 0.00 & & 2669.94 & 136.34 \\
\hline $\mathrm{Mg}$ & 0.0019 & & & 11.76 & 0.60 & & 0.00 & 0.00 & & 20.58 & 1.05 \\
\hline $\mathrm{Sb}$ & 0.0504 & & & 49.68 & 2.54 & & 0.00 & 0.00 & & 86.94 & 4.44 \\
\hline $\begin{array}{l}\text { Other } \\
\text { metals }\end{array}$ & 0.0326 & & & 22.32 & 1.14 & & 0.00 & 0.00 & & 39.06 & 1.99 \\
\hline
\end{tabular}

Table 14. Total concentration in soil for both rounds.

\begin{tabular}{|l|l|l|l|}
\hline Metals & $\begin{array}{l}\text { Control } \\
(\mathrm{mg} / \mathrm{kg})\end{array}$ & $\begin{array}{l}5 \% \text { TRAPPS } \\
(\mathrm{mg} / \mathrm{kg})\end{array}$ & $\begin{array}{l}5 \% \text { TRAPPS } \\
(\mathrm{mg} / \mathrm{kg})\end{array}$ \\
\hline $\mathrm{Pb}$ & 1553.29 & 2169.38 & 1742.03 \\
\hline $\mathrm{Cu}$ & 873.43 & 1219.86 & 979.56 \\
\hline $\mathrm{Zn}$ & 96.06 & 134.17 & 107.74 \\
\hline $\mathrm{Fe}$ & 480.85 & 671.57 & 539.28 \\
\hline $\mathrm{Mg}$ & 1.10 & 0.82 & 1.55 \\
\hline $\mathrm{Sb}$ & 15.66 & 21.88 & 17.56 \\
\hline Other metals & 9.63 & 14.15 & 10.48 \\
\hline
\end{tabular}


Table 15. Calculated $\mathrm{Pb}$ concentration in lysimeters.

\begin{tabular}{|c|c|c|c|c|c|c|c|c|c|}
\hline \multirow[b]{2}{*}{ Lysimeter } & \multirow{2}{*}{$\begin{array}{l}\mathrm{Pb} \text { in soil } \\
(\mathrm{mg} / \mathrm{kg})\end{array}$} & \multicolumn{2}{|c|}{$\begin{array}{l}\text { Soluble leachate } \\
\text { (mg/L) }\end{array}$} & \multicolumn{2}{|c|}{$\begin{array}{l}\text { Soluble runoff } \\
\qquad(\mathrm{mg} / \mathrm{L})\end{array}$} & \multicolumn{2}{|c|}{$\begin{array}{l}\text { Total leachate } \\
\qquad(\mathrm{mg} / \mathrm{L})\end{array}$} & \multicolumn{2}{|c|}{$\begin{array}{c}\text { Total runoff } \\
(\mathrm{mg} / \mathrm{L})\end{array}$} \\
\hline & & Avg. & St. Dev & Avg. & St. Dev & Avg. & St. Dev & Avg. & St. Dev \\
\hline Control & 1553.29 & 0.0265 & 0.01 & 0.1745 & 0.30 & 0.0809 & 0.16 & 2.3350 & 5.20 \\
\hline $\begin{array}{l}5 \% \\
\text { TRAPPS }^{\mathrm{TM}}\end{array}$ & 2169.38 & 0.1137 & 0.28 & 0.1398 & 0.32 & 50.1319 & 178.40 & 9.7802 & 19.48 \\
\hline $\begin{array}{l}5 \% \\
\text { TRAPPS } \\
5 \% \text { TTF }\end{array}$ & 1742.03 & 0.0365 & 0.15 & 0.0637 & 0.08 & 11.1417 & 28.56 & 0.6163 & 1.07 \\
\hline $\begin{array}{l}5 \% \\
\text { TRAPPS }^{\text {TM }}\end{array}$ & $\mathrm{n} / \mathrm{a}$ & 0.0334 & 0.02 & $n / a$ & $n / a$ & 7.8897 & 18.82 & $n / a$ & $n / a$ \\
\hline $5 \%$ TTF & $\mathrm{n} / \mathrm{a}$ & 0.0303 & 0.01 & $n / a$ & $n / a$ & 6.3549 & 13.25 & $n / a$ & $n / a$ \\
\hline
\end{tabular}

Table 16. Comparison of pre- and post-demonstration soil $\mathrm{pH}$ from the PRBerm ${ }^{\mathrm{TM}}$ lysimeters $(n=3)$.

\begin{tabular}{|c|c|c|c|c|c|c|c|}
\hline \multirow[b]{2}{*}{$\mathrm{pH}$} & \multicolumn{2}{|c|}{ Control } & \multicolumn{2}{|c|}{$5 \%$ TRAPPS $^{\mathrm{TM}}$} & \multicolumn{2}{|c|}{$\begin{array}{l}\text { 5\% TRAPPS } \\
+5 \% \text { TTF }\end{array}$} & \multirow[t]{2}{*}{$5 \%$ TTF } \\
\hline & Initial & Final & Initial & Final & Initial & Final & \\
\hline Average & 7.73 & 8.06 & 7.29 & 7.48 & 6.95 & 7.37 & 7.09 \\
\hline STDEV & 0.15 & 0.03 & 0.03 & 0.14 & 0.10 & 0.03 & 0.06 \\
\hline \% STDEV & 1.88 & 0.33 & 0.42 & 1.90 & 1.42 & 0.34 & 0.78 \\
\hline
\end{tabular}

\section{Total Metals Post-Firing}

Table 17 shows the average total (digested) metal concentrations in the post-firing bulk soil samples taken at the conclusion of the field demonstration. The unamended control lysimeter had the highest concentrations of $\mathrm{Pb}, \mathrm{Cu}, \mathrm{Zn}, \mathrm{Sb}$, and As when compared to the amended lysimeters. The lysimeter amended with TRAPPS ${ }^{\mathrm{TM}}$ had lower $\mathrm{Pb}, \mathrm{Cu}, \mathrm{Zn}$, and $\mathrm{Sb}$ concentrations than the other amended lysimeter,

\section{Toxicity Characteristic Leaching Potential (TCLP)}

The $\mathrm{Pb}$ concentration from TCLP (Table 18) was higher than the USEPA regulatory concentration level of 5-mg/ $\mathrm{L}$ for all lysimeters except for the left lysimeter inset which contained 5\% TTF. The amended lysimeters had lower TCLP metal concentrations of $\mathrm{Pb}, \mathrm{Cu}, \mathrm{Zn}, \mathrm{Sb}$, and As when compared to the unamended control lysimeter. 
Table 17. Average concentration of total (digested) metals in bulk lysimeter soil post-firing $(\mathrm{mg} / \mathrm{kg}, \mathrm{n}=3)$.

\begin{tabular}{|c|c|c|c|c|c|c|c|c|}
\hline \multirow[b]{3}{*}{ Metal } & \multicolumn{8}{|c|}{ Lysimeter } \\
\hline & \multicolumn{2}{|c|}{ Control } & \multicolumn{2}{|c|}{ 5\% TRAPPS ${ }^{\mathrm{TM}}$} & \multicolumn{2}{|c|}{ Left 5\% TRAPPS ${ }^{\text {TM }}$} & \multicolumn{2}{|c|}{ Left 5\% TTF } \\
\hline & AVG & STDEV & AVG & STDEV & AVG & STDEV & AVG & STDEV \\
\hline $\mathrm{Pb}$ & 10,215 & 1,842 & 2,477 & 894 & 6,566 & 546 & 186 & 15 \\
\hline $\mathrm{Cr}$ & ND & * & 13 & 0.5 & ND & * & 24 & 5 \\
\hline $\mathrm{Cu}$ & 905 & 249 & 354 & 12 & 628 & 12 & 95 & 22 \\
\hline $\mathrm{Ni}$ & ND & * & 8 & 0.5 & ND & * & 16 & 4 \\
\hline $\mathrm{Zn}$ & 92 & 24 & 37 & 3 & 62 & 1 & 13 & 2 \\
\hline $\mathrm{Fe}$ & 656 & 63 & 6,742 & 386 & 2,078 & 497 & 15,537 & 4,754 \\
\hline $\mathrm{Mn}$ & ND & * & 39 & 1 & 10 & 2 & 87 & 29 \\
\hline $\mathrm{Sb}$ & 115 & 16 & 28 & 15 & 74 & 16 & ND & * \\
\hline $\mathrm{Ca}$ & 372 & 26 & 3,761 & 92 & 1,098 & 7 & 4,273 & 213 \\
\hline As & 7 & 2 & ND & * & ND & * & ND & * \\
\hline $\mathrm{P} * *$ & ND & * & 2,942 & 143 & 2,098 & 96 & 3,729 & 218 \\
\hline
\end{tabular}

$\mathrm{ND}=$ non-detect. The detection limit is $0.025 \mathrm{mg} / \mathrm{Kg}$ for all metals except $\mathrm{P}$

*Not applicable

**The detection limit for $\mathrm{P}$ is $5.00 \mathrm{mg} / \mathrm{Kg}$.

Table 18. Average TCLP metal concentration of post-firing bulk lysimeter soils ( $\mathrm{mg} / \mathrm{Kg}, \mathrm{n}=3$ ).

\begin{tabular}{|c|c|c|c|c|c|c|c|c|}
\hline \multirow[b]{3}{*}{ Metal } & \multicolumn{8}{|c|}{ Lysimeter } \\
\hline & \multicolumn{2}{|c|}{ Control } & \multicolumn{2}{|c|}{$5 \%$ TRAPPS $^{\mathrm{TM}}$} & \multicolumn{2}{|c|}{ Left 5\% TRAPPS'M } & \multicolumn{2}{|c|}{ Left $5 \%$ TTF } \\
\hline & AVG & STDEV & AVG & STDEV & AVG & STDEV & AVG & STDEV \\
\hline $\mathrm{Pb}$ & 473 & 9 & 147 & 3 & 64 & 0.4 & 2 & 1 \\
\hline $\mathrm{Cr}$ & ND & * & 0.1 & 0 & 0.1 & 0 & ND & * \\
\hline $\mathrm{Cu}$ & 28 & 0 & 6 & 0.1 & 7 & 0 & ND & * \\
\hline $\mathrm{Ni}$ & $<1$ & 0 & 0.1 & 0 & 0.2 & 0 & 0.2 & 0 \\
\hline $\mathrm{Zn}$ & 3 & 0 & 1 & 0 & 1 & 0 & 0.1 & 0 \\
\hline $\mathrm{Fe}$ & 7 & 0.3 & 71 & 2 & 45 & 1 & 6 & 1 \\
\hline $\mathrm{Mn}$ & $<1$ & 0 & 2 & 0 & 1 & 0 & 1 & 0 \\
\hline Mo & ND & * & ND & * & ND & * & $<1$ & 0 \\
\hline V & ND & * & ND & * & ND & * & ND & * \\
\hline $\mathrm{Sb}$ & 5 & 0.1 & $<1$ & 0 & $<1$ & 0 & $<1$ & 0 \\
\hline
\end{tabular}

$\mathrm{ND}=$ non-detect. The detection limit is $0.025 \mathrm{mg} / \mathrm{Kg}$ for all metals.

*Not applicable 
The unamended control lysimeter, which has a higher total Pb concentration, also has the highest TCLP Pb concentration. In order to compare the $\mathrm{Pb}$ leachability ratios, the TCLP $\mathrm{Pb}$ was divided by the Total $\mathrm{Pb}$ soil concentration. The TCLP Pb was first multiplied by 20 (the ratio of liquid to solid in the TCLP procedure). The highest leachability ratio was in the $7.62 \mathrm{~mm}$ lysimeter (119.00\%) > control lysimeter (92.68\%) > Left 5\% TRAPPS $^{\mathrm{TM}}$ lysimeter (19.55\%), > inset lysimeter (18.15\%) (Table 19). The control lysimeter had a leachability ratio smaller than the amended lysimeters.

Table 19. Average TCLP Pb, Total $\mathrm{Pb}$ and the $\mathrm{Pb}$ leachability ratios (TCLP to total $\mathrm{Pb}$ )) in lysimeters.

\begin{tabular}{|c|c|c|c|}
\hline Lysimeter & $\begin{array}{l}\text { TCLP Pb } \\
\text { (mg/L) }\end{array}$ & $\begin{array}{l}\text { Total Pb } \\
\text { (mg/Kg) }\end{array}$ & $\begin{array}{l}\text { Leachability Ratio } \\
\text { (\%) }\end{array}$ \\
\hline Control & 473 & 10,215 & 93 \\
\hline $5 \%$ TRAPPS $^{\text {TM }}$ & 147 & 2,477 & 119 \\
\hline Left 5\% TRAPPS ${ }^{\text {TM }}$ & 64 & 6,566 & 20 \\
\hline Left 5\% TTF & 2 & 186 & 18 \\
\hline
\end{tabular}

Table 20 compares the TCLP metals concentrations in pre-firing soil with those in post-firing soil. TCLP concentrations in the post-firing soil increased for all metals except $\mathrm{Ca}$ and $\mathrm{P}$ which decreased in the amended lysimeters. There was an increase in post-firing soil Ca concentration for the unamended control lysimeter.

Table 21 shows the concentration of metals after TCLP extraction in the post-firing soil sampled at different dimensions. For the unamended and amended lysimeters, the farther the soil sample was taken from the bottom of the lysimeter, the higher the concentration of $\mathrm{Pb}, \mathrm{Cu}$, and $\mathrm{Zn}$ was present. The soil samples taken from the control lysimeter at all four dimensions had lower concentrations of all metals listed. The metal concentrations for each dimension varied with the amendments.

\section{DDI Suspend and Settle Leaching Procedure (DDI S\&S)}

The average concentration of metals in solution determined by the DDI S\&S procedure is shown for the bulk soil samples in Table 22. The $\mathrm{Pb}$ concentrations ranged from 0.04 to $0.56 \mathrm{mg} / \mathrm{L}$. The Left 5\% TRAPPS ${ }^{\mathrm{TM}}$ lysimeter had the lowest $\mathrm{Pb}$ concentration and the 5\% TRAPPS $^{\mathrm{TM}}$ lysimeter had the highest $\mathrm{Pb}$ concentration. 
Table 20. Comparison of average TCLP metal concentrations from pre-firing and post-firing soil $(\mathrm{mg} / \mathrm{L}, \mathrm{n}=3)$.

\begin{tabular}{|c|c|c|c|c|c|c|c|c|c|c|c|c|c|c|}
\hline \multirow[b]{4}{*}{ Metal } & \multicolumn{14}{|c|}{ Lysimeter treatment } \\
\hline & \multicolumn{4}{|c|}{ Control } & \multicolumn{4}{|c|}{$5 \%$ TRAPPS ${ }^{\mathrm{TM}}$} & \multicolumn{4}{|c|}{ Left $5 \%$ TRAPPS ${ }^{\mathrm{TM}}$} & \multirow{2}{*}{\multicolumn{2}{|c|}{$\begin{array}{c}\text { Left 5\% TFF } \\
\text { Post }\end{array}$}} \\
\hline & \multicolumn{2}{|c|}{ Pre } & \multicolumn{2}{|c|}{ Post } & \multicolumn{2}{|c|}{ Pre } & \multicolumn{2}{|c|}{ Post } & \multicolumn{2}{|c|}{ Pre } & \multicolumn{2}{|c|}{ Post } & & \\
\hline & AVG & STDEV & AVG & STDEV & AVG & STDEV & AVG & STDEV & AVG & STDEV & AVG & STDEV & AVG & STDEV \\
\hline $\mathrm{Pb}$ & ND & * & 473.37 & 8.52 & ND & * & 147.40 & 3.13 & ND & * & 64.19 & 0.38 & 1.69 & 0.78 \\
\hline $\mathrm{Cr}$ & ND & * & ND & * & ND & * & 0.05 & 0.00 & ND & * & 0.05 & 0.00 & ND & * \\
\hline $\mathrm{Cu}$ & ND & * & 28.11 & 0.12 & 0.06 & 0.03 & 4.62 & 0.08 & ND & * & 6.55 & 0.01 & 0.20 & 0.01 \\
\hline $\mathrm{Ni}$ & 0.03 & 0.00 & 0.03 & 0.00 & 0.08 & 0.01 & 0.28 & 0.00 & 0.07 & 0.01 & 0.23 & 0.00 & 0.16 & 0.00 \\
\hline $\mathrm{Zn}$ & ND & * & 2.98 & 0.04 & 0.13 & 0.01 & 1.19 & 0.01 & 0.11 & 0.00 & 1.23 & 0.02 & 0.09 & 0.00 \\
\hline $\mathrm{Fe}$ & 0.42 & 0.59 & 6.87 & 0.32 & 0.40 & 0.23 & 71.02 & 2.18 & 0.67 & 0.31 & 44.87 & 0.58 & 6.39 & 0.76 \\
\hline $\mathrm{Mn}$ & ND & * & 0.10 & 0.01 & 0.48 & 0.02 & 1.51 & 0.01 & 0.37 & 0.04 & 0.92 & 0.01 & 0.60 & 0.01 \\
\hline Mo & ND & * & ND & * & ND & * & ND & * & ND & * & ND & * & 0.03 & 0.01 \\
\hline V & ND & * & ND & * & ND & * & ND & * & ND & * & ND & * & ND & * \\
\hline $\mathrm{Sb}$ & ND & * & 5.32 & 0.09 & ND & * & 0.43 & 0.01 & ND & * & 0.08 & 0.00 & 0.03 & 0.01 \\
\hline $\mathrm{Ca}$ & 14.17 & 3.74 & 13.22 & 0.41 & 169.47 & 12.56 & 48.97 & 0.20 & 69.21 & 3.89 & 34.89 & 0.16 & 122.30 & 2.02 \\
\hline As & ND & * & 0.05 & 0.01 & ND & * & ND & * & ND & * & ND & * & ND & * \\
\hline$P * *$ & ND & * & ND & * & 12.52 & 5.06 & ND & * & 8.20 & 1.75 & ND & * & 18.79 & 0.34 \\
\hline
\end{tabular}

$\mathrm{ND}=$ non-detect. The detection limit is $0.025 \mathrm{mg} / \mathrm{L}$ except for $\mathrm{P}$.

*not applicable

**The detection limit for $\mathrm{P}$ is $5.0 \mathrm{mg} / \mathrm{L}$.

Table 21. Average post-firing TCLP metal concentrations in lysimeters at different dimensions $(\mathrm{mg} / \mathrm{L}, \mathrm{n}=3)$.

\begin{tabular}{|c|c|c|c|c|c|c|c|c|}
\hline \multirow[b]{3}{*}{ Metal } & \multicolumn{8}{|c|}{ Lysimeter and sampling depth } \\
\hline & \multicolumn{4}{|c|}{ Control } & \multicolumn{4}{|c|}{$5 \%$ TRAPPS ${ }^{\text {TM }}$} \\
\hline & 0-4'L:0-5'H & 4-8'L:0-5'H & 0-4'L:5-10H & 4-8'L:5-10’H & 0-4'L:0-5'H & 4-8'L:0-5'H & 0-4'L:5-10H & 4-8'L:5-10'H \\
\hline $\mathrm{Pb}$ & $153 \pm 38$ & $158 \pm 50$ & $277 \pm 78$ & $216 \pm 43$ & $47 \pm 48$ & $53 \pm 41$ & $144 \pm 97$ & $53 \pm 26$ \\
\hline $\mathrm{Cr}$ & ND & ND & ND & ND & $0.04 \pm 0.01$ & $0.15 \pm 0.09$ & $0.05 \pm 0.01$ & ND \\
\hline $\mathrm{Cu}$ & $5 \pm 2$ & $8 \pm 2$ & $11 \pm 3$ & $11 \pm 2$ & $3 \pm 2$ & $3 \pm 2$ & $7 \pm 4$ & $4 \pm 2$ \\
\hline $\mathrm{Ni}$ & ND & ND & ND & ND & $0.21 \pm 0.08$ & $0.37 \pm 0.09$ & $0.37 \pm 0.08$ & $0.12 \pm 0.06$ \\
\hline $\mathrm{Zn}$ & $0.73 \pm 0.23$ & $0.82 \pm 0.18$ & $1.58 \pm 0.38$ & $1.39 \pm 0.15$ & $0.77 \pm 0.60$ & $0.62 \pm 0.40$ & $1.83 \pm 0.62$ & $0.94 \pm 0.47$ \\
\hline $\mathrm{Fe}$ & $0.91 \pm 0.73$ & $1.18 \pm 0.49$ & $0.64 \pm 0.39$ & $0.36 \pm 0.24$ & $73 \pm 23$ & $99 \pm 55$ & $63 \pm 21$ & $23 \pm 11$ \\
\hline $\mathrm{Mn}$ & $0.03 \pm 0.00$ & $0.04 \pm 0.01$ & $0.04 \pm 0.01$ & $0.04 \pm 0.00$ & $0.86 \pm 0.29$ & $1.28 \pm 0.30$ & $1.46 \pm 0.36$ & $0.50 \pm 0.18$ \\
\hline Mo & ND & ND & ND & ND & ND & $0.07 \pm 0.04$ & ND & ND \\
\hline V & ND & ND & ND & ND & ND & $0.05 \pm 0.00$ & ND & ND \\
\hline $\mathrm{Sb}$ & $1.22 \pm 0.32$ & $1.43 \pm 0.27$ & $1.52 \pm 0.44$ & $1.23 \pm 0.21$ & $0.50 \pm 0.29$ & $0.95 \pm 0.85$ & $0.10 \pm 0.05$ & $0.51 \pm 0.24$ \\
\hline $\mathrm{Ca}$ & $5 \pm 1$ & $8 \pm 1$ & $6 \pm 2$ & $7 \pm 1$ & $87 \pm 34$ & $28 \pm 6$ & $52 \pm 22$ & $22 \pm 7$ \\
\hline As & ND & ND & ND & ND & ND & ND & ND & ND \\
\hline$P *$ & ND & ND & ND & ND & ND & ND & ND & ND \\
\hline
\end{tabular}

$\mathrm{ND}=$ non-detect. The detection limit is $0.025 \mathrm{mg} / \mathrm{L}$ except for $\mathrm{P}$.

*the detection limit for $P$ is $5.0 \mathrm{mg} / \mathrm{L}$. 
Table 22. Average metal concentrations ( $\mathrm{mg} / \mathrm{L}$ ) for bulk lysimeter soil samples post-DDI suspend and settle $(n=3)$.

\begin{tabular}{|l|l|l|l|l|l|l|l|l|}
\hline \multirow{2}{*}{ Metal } & \multicolumn{9}{|c|}{ Lysimeter } \\
\cline { 2 - 10 } & \multicolumn{2}{|c|}{ Control } & \multicolumn{2}{c|}{$5 \%$ TRAPPS } & \multicolumn{2}{c|}{ Left 5\% TRAPPS } & \multicolumn{2}{c|}{ Left 5\% TTF } \\
\cline { 2 - 10 } & AVG & STDEV & AVG & STDEV & AVG & STDEV & AVG & STDEV \\
\hline $\mathrm{Pb}$ & 0.37 & 0.01 & 0.44 & 0.01 & 0.04 & 0.00 & 0.36 & 0.05 \\
\hline $\mathrm{Cr}$ & ND & $*$ & ND & $*$ & ND & $*$ & ND & $*$ \\
\hline $\mathrm{Ni}$ & 0.04 & 0.00 & 0.06 & 0.00 & ND & $*$ & 0.56 & 0.02 \\
\hline $\mathrm{Zn}$ & ND & $*$ & ND & $*$ & ND & $*$ & ND & $*$ \\
\hline Fe & 0.04 & 0.00 & 0.35 & 0.00 & ND & $*$ & ND & $*$ \\
\hline $\mathrm{Mn}$ & ND & $*$ & ND & $*$ & ND & $*$ & ND & $*$ \\
\hline $\mathrm{Mo}$ & ND & $*$ & ND & $*$ & ND & $*$ & ND & $*$ \\
\hline $\mathrm{V}$ & ND & $*$ & ND & $*$ & ND & $*$ & ND & $*$ \\
\hline $\mathrm{Sb}$ & 0.15 & 0.00 & 0.17 & 0.00 & 0.29 & 0.01 & 0.20 & 0.00 \\
\hline
\end{tabular}

$\mathrm{ND}=$ non-detect. The detection limit is $0.025 \mathrm{mg} / \mathrm{Kg}$ for all metals.

*Not applicable

Table 23 compares the pre and post samples taken at the site after a DDI S\&S test. The 5\% TTF inset lysimeter only shows the results for post samples taken after firing on the range. For all three lysimeters, the $\mathrm{Pb}$, $\mathrm{Cu}$, and $\mathrm{Sb}$ concentrations were higher in the post soils than in the pre soils. There was an increase in the Fe and Ca present for the pre soils in all lysimeters. The other metals were below detection limits.

Table 24 shows the concentration of metals after DDI S\&S in the postfiring soil sampled at different dimensions. No phosphorus was detected in the unamended and the amended lysimeter. For the $\mathrm{Pb}$ concentration in the control lysimeter, the $0-4^{\prime} \mathrm{L}: 0-5^{\prime} \mathrm{H}$ sample was greater than the $0-4^{\prime} \mathrm{L}$ : $5-10$ ' $\mathrm{H}$. The control lysimeter samples taken farthest away from the bottom had higher $\mathrm{Cu}, \mathrm{Zn}, \mathrm{Fe}, \mathrm{Sb}$, and $\mathrm{Ca}$ concentrations. For example, the control samples taken at 4-8'L: 5-10' $\mathrm{H}$ had higher $\mathrm{Pb}, \mathrm{Cu}, \mathrm{Zn}, \mathrm{Sb}$, and $\mathrm{As}$ concentrations compared to samples taken closer to the bottom. The amended lysimeter also had greater $\mathrm{Pb}, \mathrm{Cu}, \mathrm{Sb}$, and As concentrations for samples taken farthest away from the bottom. 
Table 23. Comparison of average DDI S\&S metal concentrations from pre-firing and post-firing soil $(\mathrm{mg} / \mathrm{L}, \mathrm{n}=3$ ).

\begin{tabular}{|c|c|c|c|c|c|c|c|c|c|c|c|c|c|c|}
\hline \multirow[b]{4}{*}{ Metal } & \multicolumn{14}{|c|}{ Lysimeter treatment } \\
\hline & \multicolumn{4}{|c|}{ Control } & \multicolumn{4}{|c|}{$5 \%$ TRAPPS } & \multicolumn{4}{|c|}{ Left $5 \%$ TRAPPS } & \multirow{2}{*}{\multicolumn{2}{|c|}{$\frac{\text { Left } 5 \% \text { TTF }}{\text { Post }}$}} \\
\hline & \multicolumn{2}{|c|}{ Pre } & \multicolumn{2}{|c|}{ Post } & \multicolumn{2}{|c|}{ Pre } & \multicolumn{2}{|c|}{ Post } & \multicolumn{2}{|c|}{ Pre } & \multicolumn{2}{|c|}{ Post } & & \\
\hline & AVG & STDEV & AVG & STDEV & AVG & STDEV & AVG & STDEV & AVG & STDEV & AVG & STDEV & AVG & STDEV \\
\hline $\mathrm{Pb}$ & ND & * & 0.37 & 0.01 & ND & * & 0.44 & 0.01 & ND & * & 0.04 & 0.00 & 0.36 & 0.05 \\
\hline $\mathrm{Cr}$ & ND & * & ND & * & ND & * & ND & * & ND & * & ND & * & ND & * \\
\hline $\mathrm{Cu}$ & ND & * & 0.04 & 0.00 & ND & * & 0.06 & 0.00 & ND & * & ND & * & 0.56 & 0.02 \\
\hline $\mathrm{Ni}$ & ND & * & ND & * & ND & * & ND & * & ND & * & ND & * & ND & * \\
\hline $\mathrm{Zn}$ & ND & * & ND & * & ND & * & ND & * & ND & * & ND & * & 0.10 & 0.00 \\
\hline $\mathrm{Fe}$ & 0.40 & 0.04 & 0.04 & 0.00 & 1.94 & 0.32 & 0.35 & 0.00 & 2.13 & 0.16 & ND & * & ND & * \\
\hline $\mathrm{Mn}$ & ND & * & ND & * & ND & * & ND & * & ND & * & ND & * & ND & * \\
\hline Mo & ND & * & ND & * & ND & * & ND & * & ND & * & ND & * & ND & * \\
\hline V & ND & * & ND & * & ND & * & ND & * & ND & * & ND & * & ND & * \\
\hline $\mathrm{Sb}$ & ND & * & 0.15 & 0.00 & ND & * & 0.17 & 0.00 & ND & * & 0.29 & 0.01 & 0.20 & 0.00 \\
\hline $\mathrm{Ca}$ & 7.29 & 0.87 & 1.98 & 0.03 & 18.06 & 0.94 & 3.71 & 0.07 & 12.77 & 1.48 & 6.03 & 0.06 & 11.94 & 0.06 \\
\hline As & ND & * & ND & * & ND & * & ND & * & ND & * & ND & * & ND & * \\
\hline $\mathrm{P} * *$ & ND & $*$ & ND & * & ND & * & ND & * & ND & $*$ & ND & * & 18.79 & 0.20 \\
\hline
\end{tabular}

$\mathrm{ND}=$ non-detect. The detection limit is $0.025 \mathrm{mg} / \mathrm{L}$ except for $\mathrm{P}$.

* not applicable

**The detection limit for $P$ is $5.0 \mathrm{mg} / \mathrm{L}$.

Table 24. Average post-firing DDI S\&S metal concentrations in lysimeters at different dimensions $(\mathrm{mg} / \mathrm{L}, \mathrm{n}=3$ ).

\begin{tabular}{|c|c|c|c|c|c|c|c|c|}
\hline \multirow[b]{3}{*}{ Metal } & \multicolumn{8}{|c|}{ Lysimeter and sampling depth } \\
\hline & \multicolumn{4}{|c|}{ Control } & \multicolumn{4}{|c|}{$5 \%$ TRAPPS ${ }^{\text {TM }}$} \\
\hline & 0-4'L:0-5'H & 4-8'L:0-5'H & 0-4'L:5-10H & 4-8'L:5-10'H & 0-4'L:0-5'H & 4-8'L:0-5'H & 0-4'L:5-10H & 4-8'L:5-10'H \\
\hline $\mathrm{Pb}$ & $1.18 \pm 1.91$ & $0.46 \pm 0.29$ & $0.90 \pm 0.43$ & $0.97 \pm 0.48$ & $0.44 \pm 0.27$ & $1.43 \pm 1.26$ & $1.23 \pm 1.80$ & $5.47 \pm 7.68$ \\
\hline $\mathrm{Cr}$ & ND & ND & ND & ND & ND & ND & ND & ND \\
\hline $\mathrm{Cu}$ & $0.13 \pm 0.12$ & $0.10 \pm 0.05$ & $0.15 \pm 0.05$ & $0.25 \pm 0.24$ & $0.12 \pm 0.08$ & $0.16 \pm 0.12$ & $0.22 \pm 0.16$ & $0.77 \pm 1.05$ \\
\hline $\mathrm{Ni}$ & ND & ND & ND & ND & ND & ND & ND & ND \\
\hline $\mathrm{Zn}$ & $0.02 \pm 0.02$ & ND & $0.03 \pm 0.00$ & $0.03 \pm 0.00$ & ND & ND & $0.05 \pm 0.04$ & ND \\
\hline $\mathrm{Fe}$ & $0.12 \pm 0.07$ & $0.09 \pm 0.02$ & $0.15 \pm 0.08$ & $0.09 \pm 0.05$ & $0.77 \pm 0.88$ & $0.45 \pm 0.31$ & $0.60 \pm 0.21$ & $17.64 \pm 24.43$ \\
\hline $\mathrm{Mn}$ & ND & ND & ND & ND & ND & ND & ND & $0.20 \pm 0.22$ \\
\hline Mo & ND & ND & ND & ND & ND & ND & ND & ND \\
\hline V & ND & ND & ND & ND & ND & ND & ND & ND \\
\hline $\mathrm{Sb}$ & $0.17 \pm 0.06$ & $0.13 \pm 0.05$ & $0.27 \pm 0.12$ & $0.21 \pm 0.06$ & $0.12 \pm 0.09$ & $0.22 \pm 0.07$ & $0.32 \pm 0.11$ & $0.13 \pm 0.10$ \\
\hline $\mathrm{Ca}$ & $1.16 \pm 0.41$ & $1.32 \pm 0.42$ & $1.49 \pm 0.69$ & ND & $6.39 \pm 1.14$ & ND & ND & ND \\
\hline As & ND & ND & ND & $1.36 \pm 0.65$ & ND & $4.94 \pm 0.86$ & $4.72 \pm 0.68$ & $12.16 \pm 8.11$ \\
\hline$P *$ & ND & ND & ND & ND & ND & ND & ND & ND \\
\hline
\end{tabular}

$\mathrm{ND}=$ non-detect. The detection limit is $0.025 \mathrm{mg} / \mathrm{L}$ except for $\mathrm{P}$.

*the detection limit for $P$ is $5.0 \mathrm{mg} / \mathrm{L}$. 


\section{Synthetic Precipitation Leaching Procedure (SPLP)}

As can be seen in Table 25, the pre SPLP Fe concentration for the control lysimeter was $0.20 \mathrm{ppm}$ and $0.06 \mathrm{ppm}$ for the post soil SPLP concentration. The Left 5\% TRAPPS ${ }^{\mathrm{TM}}$ also showed a decrease in the post soil $\mathrm{Fe}$ concentration. For the post samples, the inset lysimeter had $0.12 \mathrm{ppm} \mathrm{Pb}$ and the control had $2.46 \mathrm{ppm} \mathrm{Pb}$. The post $\mathrm{Pb}$ and $\mathrm{Cu}$ concentrations for the $7.62 \mathrm{~mm}$ and Left 5\% TRAPPS ${ }^{\mathrm{TM}}$ lysimeters were also less the control lysimeter.

Table 26 shows the SPLP leaching concentrations for the post soils. The $\mathrm{Pb}$ concentration was highest in the leachate from the control lysimeter, followed by the $7.62 \mathrm{~mm}$ lysimeter, Left 5\% TRAPPS ${ }^{\mathrm{TM}}$, and the inset lysimeter. The control lysimeter had higher $\mathrm{Cu}$ and $\mathrm{Zn}$ concentrations compared to the other three samples. More $\mathrm{Sb}$ was leached from the Left $5 \%$ TRAPPS $^{\mathrm{TM}}$ and more Fe from the $7.62 \mathrm{~mm}$ lysimeter when compared to the other lysimeters.

Table 25. Comparison of average SPLP metal concentrations from pre-firing and post-firing soil $(\mathrm{mg} / \mathrm{L}, \mathrm{n}=3)$.

\begin{tabular}{|c|c|c|c|c|c|c|c|c|c|c|c|c|c|c|}
\hline \multirow[b]{4}{*}{ Metal } & \multicolumn{14}{|c|}{ Lysimeter treatment } \\
\hline & \multicolumn{4}{|c|}{ Control } & \multicolumn{4}{|c|}{$5 \%$ TRAPPS } & \multicolumn{4}{|c|}{ Left $5 \%$ TRAPPS ${ }^{\mathrm{TM}}$} & \multirow{2}{*}{\multicolumn{2}{|c|}{$\frac{\text { Left } 5 \% \text { TFF }}{\text { Post }}$}} \\
\hline & \multicolumn{2}{|c|}{ Pre } & \multicolumn{2}{|c|}{ Post } & \multicolumn{2}{|c|}{ Pre } & \multicolumn{2}{|c|}{ Post } & \multicolumn{2}{|c|}{ Pre } & \multicolumn{2}{|c|}{ Post } & & \\
\hline & AVG & STDEV & AVG & STDEV & AVG & STDEV & AVG & STDEV & AVG & STDEV & AVG & STDEV & AVG & STDEV \\
\hline $\mathrm{Pb}$ & 0.03 & 0.00 & 2.46 & 2.65 & 0.03 & 0.00 & 0.53 & 0.41 & 0.03 & 0.00 & 0.13 & 0.01 & 0.12 & 0.04 \\
\hline $\mathrm{Cr}$ & 0.03 & 0.00 & 0.03 & 0.00 & 0.03 & 0.00 & 0.03 & 0.00 & 0.03 & 0.00 & 0.03 & 0.00 & 0.03 & 0.00 \\
\hline $\mathrm{Cu}$ & 0.03 & 0.00 & 0.62 & 0.59 & 0.03 & 0.00 & 0.13 & 0.08 & 0.03 & 0.00 & 0.09 & 0.00 & 0.03 & 0.01 \\
\hline $\mathrm{Ni}$ & 0.03 & 0.00 & 0.03 & 0.00 & 0.03 & 0.00 & 0.03 & 0.00 & 0.03 & 0.00 & 0.03 & 0.00 & 0.03 & 0.00 \\
\hline $\mathrm{Zn}$ & 0.03 & 0.00 & 0.15 & 0.11 & 0.03 & 0.00 & 0.03 & 0.00 & 0.03 & 0.00 & 0.05 & 0.00 & 0.03 & 0.00 \\
\hline $\mathrm{Fe}$ & 0.20 & 0.03 & 0.06 & 0.06 & 0.03 & 0.00 & 0.40 & 0.29 & 0.24 & 0.05 & 0.07 & 0.01 & 0.18 & 0.02 \\
\hline $\mathrm{Mn}$ & 0.03 & 0.00 & 0.03 & 0.00 & 0.03 & 0.00 & 0.03 & 0.00 & 0.03 & 0.00 & 0.05 & 0.00 & 0.03 & 0.00 \\
\hline Mo & 0.03 & 0.00 & 0.03 & 0.00 & 0.03 & 0.00 & 0.03 & 0.00 & 0.03 & 0.00 & 0.03 & 0.00 & 0.03 & 0.00 \\
\hline V & 0.03 & 0.00 & 0.03 & 0.00 & 0.03 & 0.00 & 0.03 & 0.00 & 0.03 & 0.00 & 0.03 & 0.00 & 0.03 & 0.00 \\
\hline $\mathrm{Sb}$ & 0.03 & 0.00 & 0.21 & 0.06 & 0.03 & 0.00 & 0.12 & 0.01 & 0.03 & 0.00 & 0.38 & 0.01 & 0.03 & 0.00 \\
\hline $\mathrm{Ca}$ & 4.72 & 0.13 & 2.71 & 1.05 & 17.50 & 0.42 & 4.67 & 2.25 & 10.21 & 5.50 & 21.73 & 0.55 & 8.68 & 0.62 \\
\hline As & 0.03 & 0.00 & 0.03 & 0.00 & 0.03 & 0.00 & 0.03 & 0.00 & 0.03 & 0.00 & 0.03 & 0.00 & 0.03 & 0.00 \\
\hline
\end{tabular}

ND = non-detect. The detection limit is $0.025 \mathrm{mg} / \mathrm{L}$ except for $\mathrm{P}$.

* not applicable 
Table 26. Average metal concentrations ( $\mathrm{mg} / \mathrm{L}$ ) for bulk lysimeter soil samples post-SPLP $(n=3)$.

\begin{tabular}{|l|l|l|l|l|l|l|l|l|}
\hline \multirow{2}{*}{ Metal } & \multicolumn{9}{|c|}{ Lysimeter } \\
\cline { 2 - 9 } & \multicolumn{2}{|c|}{ Control } & \multicolumn{2}{c|}{$5 \%$ TRAPPS } & \multicolumn{2}{c|}{ Left 5\% TRAPPS } & \multicolumn{2}{c|}{ Left 5\% TTF } \\
\cline { 2 - 9 } $\mathrm{Pb}$ & 2.46 & 2.65 & 0.53 & 0.41 & 0.13 & 0.01 & 0.12 & 0.04 \\
\hline $\mathrm{Cr}$ & 0.03 & 0.00 & 0.03 & 0.00 & 0.03 & 0.00 & 0.03 & 0.00 \\
\hline $\mathrm{Cu}$ & 0.62 & 0.59 & 0.13 & 0.08 & 0.09 & 0.00 & 0.03 & 0.01 \\
\hline $\mathrm{Ni}$ & 0.03 & 0.00 & 0.03 & 0.00 & 0.03 & 0.00 & 0.03 & 0.00 \\
\hline $\mathrm{Zn}$ & 0.15 & 0.11 & 0.03 & 0.00 & 0.05 & 0.00 & 0.03 & 0.00 \\
\hline $\mathrm{Fe}$ & 0.06 & 0.06 & 0.40 & 0.29 & 0.07 & 0.01 & 0.18 & 0.02 \\
\hline $\mathrm{Mn}$ & 0.03 & 0.00 & 0.03 & 0.00 & 0.05 & 0.00 & 0.03 & 0.00 \\
\hline $\mathrm{Mo}$ & 0.03 & 0.00 & 0.03 & 0.00 & 0.03 & 0.00 & 0.03 & 0.00 \\
\hline $\mathrm{V}$ & 0.03 & 0.00 & 0.03 & 0.00 & 0.03 & 0.00 & 0.03 & 0.00 \\
\hline $\mathrm{Sb}$ & 0.21 & 0.06 & 0.12 & 0.01 & 0.38 & 0.01 & 0.03 & 0.00 \\
\hline $\mathrm{ND}$ & & & AVG & STDEV & AVG & STDEV & AVG & STDEV \\
\hline
\end{tabular}

$\mathrm{ND}=$ non-detect. The detection limit is $0.025 \mathrm{mg} / \mathrm{Kg}$ for all metals.

*Not applicable

\section{Partition Coefficient $\left(K_{d}\right)$}

The data generated from the $\mathrm{Pb}$ and $\mathrm{Sb}$ sorption $\mathrm{K}_{\mathrm{d}}$ experiments yielded adsorption isotherms for each soil type in the three lysimeters. Metal soil concentrations were obtained by subtracting the concentration of the given metal from the total mass of metal added to the system. While filtering is a possible source of metal loss, standard procedure for $K_{d}$ determination using the batch method involves analysis of a filtered solution. The material retained on the filter is defined as insoluble material (USEPA 1999). Complete data for each lysimeter is available in Appendix A. A representative example is given here for linear isotherms obtained from the experimental soils.

\section{Linear Isotherm for Sb III and Sb V}

Results from triplicate metal analyses (including average and standard deviation) for each soil is included in Appendix A. A summary of the results of a linear fit determination of sorption $K_{d}$ using a section of the curve in the linear region (per $\mathrm{K}_{\mathrm{d}}$ discussion in USEPA 1999) is provided. In each of the tables, the phrase " $\mathrm{r}^{2}$ values for all data points" reflect points from all concentrations. The phrase "all data points" refers to the entire plot of $\mathrm{C}_{\text {is }} \mathrm{vs.}$ $\mathrm{C}_{\mathrm{iw}}$ used to determine the shape of the isotherm. A least squares fit was 
performed using selected points in the linear portion of the isotherm to produce a $K_{d}$ value that is valid for the entire concentration range.

The Sb III $K_{d}$ values ranged from a high of 15.77 (Left TRAPPSтм) to a low of 0.75 (Control) (Table 27). The Sb V K $\mathrm{d}_{\mathrm{d}}$ values ranged from a high of 1.51 (Left TRAPPS'м) to a low of 0.49 (Control). All three lysimeter soils had low $K_{d 100}$ values $(<10)$.

Table 27. Summary of $\mathrm{Sb}(\mathrm{III})$ and $\mathrm{Sb}(\mathrm{V})$ linear $\mathrm{K}_{d}$ data.

\begin{tabular}{|c|c|c|c|c|}
\hline \multirow[b]{2}{*}{ Lysimeter } & \multicolumn{2}{|c|}{$\mathrm{Sb}(\mathrm{III})$} & \multicolumn{2}{|c|}{$\mathrm{Sb}(\mathrm{V})$} \\
\hline & K & $\mathrm{R}^{2}$ & K & $\mathrm{R}^{2}$ \\
\hline Control & 0.75 & 1.00 & 0.49 & 0.91 \\
\hline $5 \%$ TRAPPS $^{\text {TM }}$ & 8.81 & 0.91 & 0.64 & 0.98 \\
\hline Left $5 \%$ TRAPPS ${ }^{\mathrm{TM}}+5 \%$ TTF & 15.77 & 0.96 & 1.51 & 0.96 \\
\hline
\end{tabular}




\section{Conclusions and Recommendations}

In a SAFR design where native soil is being replaced with an impact material, the need to control migration of heavy metals from the range is the reduction of $\mathrm{Pb}$ in surface and ground water. Leachate in these designed systems can be minimized or eliminated by the use of low permeability barriers during construction and renovation. From the standpoint of mobility, heavy metal cations in the bullet matrix (e.g., $\mathrm{Pb}$ and $\mathrm{Cu}$ ), have a low potential for migration off-range due to the low solubility constants of these metals and their salts in soil (Alloway 1995). Most in situ stabilization amendments at military small arms firing ranges are designed to immobilize or reduce $\mathrm{Pb}$ mobility. A variety of phosphate $\left(\mathrm{PO}_{4}\right)$ based amendments have been tested for in situ $\mathrm{Pb}$ stabilization in soil (Cao et al. 2003; Chen et al. 2006). Phosphate has been shown to sequester $\mathrm{Pb}$ in forms that are insoluble and biologically unavailable (Dermatas et al. 2006; Tandy et al. 2003; USEPA 2001a). Application of soluble or solid phase phosphate (such as hydroxyapatite, HAP) amendments have been shown to result in the formation of $\mathrm{Pb}$-phosphate minerals such as pyromorphite $\left[\mathrm{Pb}_{5}\right.$ $\left(\mathrm{PO}_{4}\right) 3 \mathrm{X}$ where $\mathrm{X}$ can be $\left.\mathrm{Cl}^{-}, \mathrm{OH}^{-}, \mathrm{F}^{-}\right]$. As suggested in Chrysochoou et al. (2007), the influence of phosphorus on co-contaminants such as oxyanions should be addressed.

In order to evaluate the impact of bullets deposited at shooting ranges onto soils and the areas surrounding the range, the behavior of bullets needs to be understood. Concentrations of $\mathrm{Pb}$ in pore water from shooting range soils or in groundwater or water bodies nearby are scarce (Labare et al. 2004). Many investigators have tested the leachability of $\mathrm{Pb}$ from shooting range soils, but these are mostly batch study experiments (Leuz 2006). Leaching experiments closer to field conditions are needed to better assess the capacity of soils to release $\mathrm{Pb}$ and other metals.

The results of this study indicate that variation in the amount and type of rounds fired into berms has an effect on the $\mathrm{Pb}$ concentrations contained in leachate and runoff. The control lysimeter had the least amount of rounds fired into the impact area, which caused it to have the lowest $\mathrm{Pb}$ concentration. The $7.62 \mathrm{~mm}$ lysimeter that was amended with $5 \%$ TRAPPS $^{\mathrm{TM}}$ had the highest total $\mathrm{Pb}$ concentrations in both leachate and 
runoff. This is not what was expected due to the fact that this was an amended lysimeter. Based on current controlled treatability studies, it was hypothesized that the amended cells yield a lower concentration of $\mathrm{Pb}$.

The inset lysimeter that contained 5\% TTF passed the regulatory limits for $\mathrm{Pb}, \mathrm{Cr}, \mathrm{Ni}$, As, and $\mathrm{Sb}$. This means that the soil could be disposed of in a non-hazardous waste landfill. If the amount of a particular chemical or metal exceeds the regulatory limits, the sample is considered hazardous and must be handled according to certain regulations. Non-hazardous waste provides a low cost disposal option as compared to hazardous waste. For the TCLP tests, there was a decrease seen in the concentration of $\mathrm{Pb}$ for the amended lysimeters when compared to the unamended lysimeter. Even though both amendments decrease $\mathrm{Pb}$ concentrations, the inset lysimeter that contained the thermally treated fishbones performed the best. 


\section{References}

Ackermann, S., R. Gieré, M. Newville, and J . Majzlan. 2009. Antimony sinks in the weathering crust of bullets from Swiss shooting ranges. Science of the Total Environment 407: 1669-1682.

Alloway, B. J . 1995. Soil Processes and the Behaviour of Heavy Metals. In Heavy Metals in Soils, ed. B. J . Alloway, 11- 37, 354. London, UK: Blackie Academic and Professional.

American Public Health Association. 1998. Standard methods for the examination of water and wastewater, 20th ed. Method 3010. ed. Andrew D. Eaton, Lenore S. Clesceri, Arnold E. Greenberg, Mary Ann H. Franson, prepared and published jointly by American Public Health Association, American Water Works Association, Water Environment Federation, Washington, DC.

Anderson, P. R., and T. H. Christensen. 1988. Distribution coefficients of Cd, Co, Ni, and $\mathrm{Zn}$ in soils. J ournal of Soil Science 39: 15-22.

Berti, W. R., and S. D. Cunningham. 1997. In-place inactivation of Pb in Pb-contaminated soils. Environmental Science and Technology 31: 1359-1364.

Bradl, H. 2004. Adsorption of heavy metal ions on soils and soil constituents. J . Colloid Interf. Sci. 277: 1-18.

Cao, X., L. O. Ma, M. Chen, D. W. Hardison, J r., and W. G. Harris. 2003. Weathering of lead bullets and their environmental effects at outdoor shooting ranges. J . Environ. Qual. 32: 526-534.

Carlon, C., M. Dalla Valle, and A. Marcomini. 2004. Regression models to predict water soil heavy metals partition coefficients in risk assessment studies. Environmental Pollution 127(1): 109-115.

Chen, Y-W., T-L. Deng, M. Filella, and N. Belzile, 2003. Distribution and early diagenesis of antimony species in sediments and porewaters of freshwater lakes. Environ. Sci. Technol. 37: 1163-1168.

Chen, Z., Y. Cai, H. Solo-Gabriele, G. H. Snyder, and J . L. Cisar. 2006. Interactions of arsenic and the dissolved substances derived from turf soils. Environmental Science \& Technology 40(15): 4659-4665.

Chrysochoou, M., D. Dermatas, and D. G. Grubb. 2007. Phosphate application to firing range soils for $\mathrm{Pb}$ immobilization: The unclear role of phosphate. J. Haz. Mats. 144: 1-14.

Conca, J . L., and J . Wright. 2006. An Apatite II permeable reactive barrier to remediate groundwater containing Zn, Pb and Cd. Appl. Geochem. 21: 1288-1300.

Conca, J . L., N. Lu, G. Parker, B. Moore, A. Adams, J. Wright, and P. Heller. 2000. PIMS remediation of metal contaminated waters and soils. Remediation of Chlorinated Recalcitrant Compounds 7: 319-326. 
Covelo, E. F., F. A. Vega, and M. L. Andrade. 2007. Competitive sorption and desorption of heavy metals by individual soil components. J ournal of Hazardous Materials 140(1-2): 308-315.

Dermatas, D., X. Cao, V. Tsaneva, G. Shen, and D. G. Grubb. 2006. Fate and behavior of metal(loid) contaminants in an organic matter-rich shooting range soil: Implications for remediation. Water, Air and Soil Pollution: Focus. 6: 143-155.

Ford, R. G., P. M. Bertsch, and K. J . Farley.1997. Changes in transition and heavy metal partitioning during hydrous iron oxide aging. Environ. Sci. Technol. 31: 20282033.

Hamon, R. E., M. J . McLaughlin, and G. Cozens. 2002. Mechanisms of attenuation of metal availability in in situ remediation treatments. Environmental Science \& Technology 36: 3991- 3996.

Han, R., Z. Lu, W. Zou, W. Daotong, J. Shi, and Y. Jiujun. 2006. Removal of copper(II) and lead(II) from aqueous solution by manganese oxide coated sand II. Equilibrium study and competitive adsorption. J . Haz. Mats. 137: 480-488.

Hettiarachichi, G. M., G. M. Pierzynski, and M. D. Ransom. 2002. In situ stabilization of soil lead using phosphorus and manganese oxide. Environ. Sci. Technol. 34:46144619 .

Hooda, P. S., and B. J . Alloway, 1998. Cadmium and lead sorption behaviour of selected English and Indian soils. Geoderma 84(1-3): 121-134.

Impelliteri, C. A., Y. Lu, J . K. Saxe, H .E. Allen, and W. J . G. M. Peijnenburg. 2002. Correlation of the partitioning of dissolved organic matter fractions with the desorption of $\mathrm{Cd}, \mathrm{Cu}, \mathrm{Ni}, \mathrm{Pb}$ and $\mathrm{Zn}$ from 18 Dutch soils. Environ. Intl. 28: 401410.

Interstate Technology and Regulatory Council (ITRC). 2003. Characterization and remediation of soils at closed small arms firing ranges.

J anssen, R. P. T., W. J . G. M. Peijnenburg, L. Posthuma, and M. A. G. T. van den Hoop. 1997. Equilibrium partitioning of heavy metals in Dutch field soils. 1. Relationship between metal partition coefficients and soil characteristics. Environmental Toxicology \& Chemistry 16(12): 2470-2478.

J ohnson, C. A., H. Moench, P. Wersin, P. Kugler, and C. Wenger, 2005. Solubility of antimony and other elements in samples taken from shooting ranges. J. Environ. Qual. 34: 248-254.

Kilgour, D. W., R. B. Moseley, M. O. Barnett, K. S. Savage, and P. M. J ardine. 2008. Potential negative consequences of adding phosphorus-base fertilizers to immobilize lead in soil. J. Environ. Qual. 37: 1733-1740.

Klitzke, S., and F. Lang, 2009. Mobilization of soluble and dispersible lead, arsenic, and antimony in a polluted, organic-rich soil - Effects of $\mathrm{pH}$ increase and counterion valency. J . Environ. Qual. 38: 933-939. 
Labare, M. P., M. A. Butkus, D. Riegner, N. Schommer, and J . Atkinson. 2004. Evaluation of lead movement from the abiotic to biotic at a small-arms firing range. Environ. Geol. 46:750-754.

Lambert, M., G. Pierzynski, L. Erickson, and J . Schnoor. 1997. Remediation of lead-, zinc and cadmium-contaminated soils. In Issues in environmental science and technology; No. 7, Contaminated land and its reclamation ed. R. E. Hester and R. M. Harrison, 91-102. Herts, United Kingdom: The Royal Society of Chemistry.

Larson, S. L., P. G. Malone, C. A. Weiss, W. A. Martin, C. Trest, G. Fabian, M. F. Warminsky, D. Mackie, J. J. Tasca, J . Wildey, J . Wright. 2007. Amended Ballistic Sand Studies to Provide Low Maintenance Lead Containment at Active Small Arms Firing Range Systems. ERDC TR-07-14. Vicksburg, MS: U.S. Army Engineer Research and Development Center.

Leuz, A. K. 2006. Redox reactions of antimony in the aquatic and terrestrial environment. Ph.D. thesis, Swiss Federal Institute of Technology (ETH) Zurich.

Lower, S. K., P. A. Maurice, and S. J . Traina. 1998. Simultaneous dissolution of hydroxylapatite and precipitation of hydroxypyromorphite: Direct evidence of homogeneous nucleation. Geoch. Cosmoch. Acta 62: 1773-1780.

Lu, N., J . Xu, J . Wright, and J . L. Conca. 2001. PIMS-remediation of metal-contaminated groundwater and soil using a special reactive form of the mineral apatite. Appl. Miner. Res. Econ. Technol., Ecol. Culture 2: 603-606.

Ma, Q. Y., and G. N. Rao. 1997. Effects of phosphate rock on sequential chemical extraction of lead in contaminated soils. J . of Environmental Quality 26:788794.

Ma, Q. Y., S. J . Traina, T. J . Logan, and J . A. Ryan. 1994. Effects of aqueous Al, Cd, Cu, $\mathrm{Fe}(\mathrm{II}), \mathrm{Ni}$, and $\mathrm{Zn}$ on $\mathrm{Pb}$ immobilization by hydroxyapatite. Environmental Science and Technology 28: 1219-1228.

Martin, W. A., S. L. Larson, D. R. Felt, J . Wright, C. S. Griggs, M. Thompson, J . L. Conca, and C. C. Nestler.2008. The effect of organics on lead sorption onto Apatite II. Appl. Geochem. 23: 34-43.

Martinez, C. E., and M. B. McBride. 1998. Solubility of $\mathrm{Cd}^{2+}, \mathrm{Cu}^{2+}, \mathrm{Pb}^{2+}$, and $\mathrm{Zn}^{2+}$ in aged coprecipitates with amorphous iron hydroxides. Environ. Sci. Technol. 32: 743748.

Martínez, C. E., S. Sauvé, A. J acobson, and M. B. McBride. 1999. Thermally induced release of adsorbed $\mathrm{Pb}$ upon aging ferrihydrite and soil oxides. Environ. Sci. Technol. 33: 2016- 2020.

McBride, M. B., B. Richards, T. Steenhuis, J . J . Russo, and S. Sauve. 1997. Mobility and solubility of toxic metals and nutrients in soils fifteen years after sludge application. Soil Science 162:487-496.

Moreno, A. M., J . R. Quintana, L. Pérez, and J . G. Parra. 2006. Factors influencing lead sorption- desorption at variable added metal concentrations in Rhodoxeralfs. Chemosphere 64(5): 758-763. 
Ndiba, P., L. Axe, and T. Boonfueng, 2008. Heavy metal immobilization through phosphate and thermal treatment of dredged sediments. Environ. Sci. Technol., 42: 920-926.

Orsetti, S., M. de las Mercedes Quiroga, and E. M. Andrade, 2006. Binding of Pb(II) in the system humic acid/ goethite at acidic pH. Chemosphere 65: 2313-2321.

Pearson, M. S., K. Maenpaa, and G. M. Pierzynski. 2000. Effects of soil amendments on the bioavailability of lead, zinc and cadmium to earthworms. J ournal of Environmental Quality 29: 1611-17.

Santillian-Medrano J , J . J . J utinak. 1975. The chemistry of lead and cadmium in soil: Solid phase formation. Soil Sci Soc Am Proc 39:851-856.

Shinomiya, T., K. Shinomiya, C. Orimoto, T. Minami, Y. Tohno, and M. Yamada. 1998. In- and out-flows of elements in bones embedded in reference soils. Forensic Sci. Int. 98: 109-118.

Slater, UK. 2010. http://www.slateruklimited.co.uk/us/trapps_firing_range.html

Tardy, B. A., R. M. Bricka, and S. L. Larson. 2003. Chemical stabilization of lead in small arms firing range soils. ERDC/ EL TR-03-20. Vicksburg, MS: U.S. Army Engineer Research and Development Center.

Traina, S. J ., and V. Laperche. 1999. Contaminant bioavailability in soils, sediments, and aquatic environments. Proc. Natl. Acad. Sci. USA 96: 3365-3371.

Trivedi, P., and L. Axe. 2000. Modeling Cd and Zn sorption to hydrous metal oxides. Environ. Sci. Technol. 34: 2215-2223.

U.S. Environmental Protection Agency (USEPA). 1999a. Test methods for evaluating solid waste, physical/ chemical methods. SW-846. Washington, DC. . 1999b. Understanding Variations in Partition Coefficient, $K_{d}$, Values. 402-R99-004B. Washington, DC.

. 2001a. Indoor Environment Division: Lead fact sheet. Office of Emergency and Remedial Response. www.epa.gov/iaq/lead.html

. 2001b. Best management practices for lead at outdoor shooting ranges. EPA/902-B-01-001. New York: RCRA Compliance Branch.

Vaccari, D. A. 1992. Computation of aqueous metal solubilities using spreadsheet programs. Hoboken, NJ : Stevens Institute of Tech. Available at: http://www.attila.stevens-tech.edu

Wilson, S. C., P. V. Lockwood, P. M. Ashley, and M. Tighe, 2006. The chemistry and behavior of antimony in the soil environment with comparisons to arsenic: A critical review. Environ. Pollut. 158: 1169-1181.

Wright, J ., K. R. Rice, B. Murphy, and J . L. Conca. 2004. PIMS using Apatite II: Remediation of Pb-contaminated range soil at Camp Stanley storage activity, TX. Proceedings of the Conference on Sustainable Range Management. New Orleans, LA. 
Yang, J ., D. Mosby, S. W. Casteel, and R. W. Blanchard. 2001. Lead immobilization using phosphoric acid in a smelter-contaminated urban soil. Environmental Science and Technology 35: 3553-3559.

Zhou, L. X., and J. W. C.Wong 2001. Effect of dissolved organic matter from sludge and sludge compost on soil copper sorption. J . Environ Qual 30:878-883. 


\section{Appendix A: Field Data}

\section{Aqueous Samples - Volume}

Table A1. Volume of leachate and runoff.

\begin{tabular}{|c|c|c|c|c|c|c|c|}
\hline \multirow[b]{2}{*}{ Sample date } & \multicolumn{2}{|c|}{ Control } & \multicolumn{2}{|c|}{$5 \%$ TRAPPS $^{\text {TM }}$} & \multirow{2}{*}{\begin{tabular}{|l|l}
$\begin{array}{l}\text { Left } 5 \% \\
\text { TRAPPS }\end{array}$ \\
leachate \\
\end{tabular}} & \multirow{2}{*}{\begin{tabular}{|l|}
$\begin{array}{l}\text { Left } 5 \% \\
\text { TTF }\end{array}$ \\
leachate \\
\end{tabular}} & \multirow{2}{*}{\begin{tabular}{|l|}
$5 \%$ TRAPPS + \\
$5 \%$ TTF \\
runoff
\end{tabular}} \\
\hline & leachate & runoff & leachate & runoff & & & \\
\hline 04/08/2009 & 1.07 & 2.02 & 2.01 & 1.49 & 0.37 & 0.50 & 1.06 \\
\hline $04 / 22 / 2009$ & 0.98 & 1.76 & 1.00 & 1.81 & NS & NS & 0.64 \\
\hline $05 / 20 / 2009$ & 0.96 & 2.13 & 2.09 & 2.12 & 1.05 & 1.04 & 1.00 \\
\hline $06 / 03 / 2009$ & 1.00 & 1.75 & 0.35 & 1.01 & 1.07 & 0.42 & 1.07 \\
\hline $06 / 17 / 2009$ & 1.03 & 2.15 & 2.14 & 1.80 & 1.04 & 0.12 & 1.11 \\
\hline 07/01/2009 & 0.86 & 1.07 & NS & NS & 1.06 & NS & 1.09 \\
\hline 07/15/2009 & 1.06 & 1.41 & 1.63 & 0.16 & 0.87 & NS & 0.99 \\
\hline $07 / 29 / 2009$ & 1.05 & 0.82 & NS & NS & NS & NS & NS \\
\hline $08 / 12 / 2009$ & 1.19 & 2.08 & 1.80 & 0.32 & NS & NS & 0.79 \\
\hline $08 / 26 / 2009$ & 1.17 & 0.56 & 2.04 & NS & 1.06 & 1.06 & NS \\
\hline 09/09/2009 & 0.98 & 1.02 & 1.00 & NS & 1.00 & NS & NS \\
\hline $10 / 07 / 2009$ & 0.99 & 1.24 & NS & NS & NS & 0.37 & 0.29 \\
\hline $10 / 21 / 2009$ & 1.04 & 1.01 & NS & NS & NS & NS & 0.68 \\
\hline $11 / 04 / 2009$ & NS & 1.07 & NS & NS & 1.07 & NS & NS \\
\hline $11 / 18 / 2009$ & 1.16 & 1.19 & NS & 0.63 & 0.16 & 1.15 & 0.92 \\
\hline $12 / 02 / 2009$ & 1.07 & 1.02 & NS & 0.94 & 1.04 & NS & NS \\
\hline $12 / 16 / 2009$ & 1.08 & 2.07 & 1.89 & 1.15 & 1.03 & NS & 1.03 \\
\hline $12 / 30 / 2009$ & 1.06 & 1.96 & 0.40 & 1.63 & 1.08 & 1.02 & 0.42 \\
\hline 01/13/2010 & 1.07 & 0.66 & NS & NS & 0.28 & NS & NS \\
\hline $01 / 27 / 2010$ & 1.07 & 1.81 & 1.92 & 2.12 & 1.07 & 1.02 & 0.98 \\
\hline 02/10/2009 & 1.07 & 2.11 & 0.82 & NS & 0.89 & NS & 0.94 \\
\hline 02/24/2010 & NS & 1.01 & 1.47 & NS & 1.04 & 0.96 & 1.02 \\
\hline 03/10/2010 & NS & NS & NS & NS & NS & NS & NS \\
\hline 03/24/2010 & NS & 2.15 & 0.45 & 2.15 & 1.08 & 0.89 & 0.83 \\
\hline 04/07/2010 & 1.06 & 0.71 & NS & 1.26 & 1.30 & NS & 0.74 \\
\hline 06/17/2010 & 1.03 & 1.31 & 0.93 & 2.10 & 1.05 & 1.02 & 1.02 \\
\hline
\end{tabular}

NS = no sample 


\section{Aqueous Samples - pH}

Table A2. $\mathrm{pH}$ values of leachate and runoff.

\begin{tabular}{|c|c|c|c|c|c|c|c|}
\hline \multirow[b]{2}{*}{ Sample date } & \multicolumn{2}{|c|}{ Control } & \multicolumn{2}{|c|}{$5 \%$ TRAPPS $^{\mathrm{TM}}$} & \multirow{2}{*}{\begin{tabular}{|l|} 
Left $5 \%$ \\
TRAPPS \\
leachate \\
\end{tabular}} & \multirow{2}{*}{\begin{tabular}{|l} 
Left $5 \%$ \\
TTF
\end{tabular}} & \multirow{2}{*}{\begin{tabular}{|l|}
$5 \%$ TRAPPS + \\
$5 \%$ TTF \\
runoff \\
\end{tabular}} \\
\hline & leachate & runoff & leachate & runoff & & & \\
\hline 04/08/2009 & 6.46 & 6.31 & 7.11 & 7.17 & 7.31 & 7.24 & 6.77 \\
\hline $04 / 22 / 2009$ & 7.06 & 6.25 & 7.53 & 6.83 & NS & NS & 6.80 \\
\hline 05/20/2009 & 6.83 & 6.24 & 6.83 & 6.99 & 6.99 & 7.15 & 6.57 \\
\hline 06/03/2009 & 6.82 & 6.03 & 6.66 & 6.43 & 6.81 & 7.06 & 6.43 \\
\hline 06/17/2009 & 6.92 & 6.16 & 6.54 & 6.56 & 7.05 & 7.51 & 7.10 \\
\hline 07/01/2009 & 7.06 & 6.96 & NS & NS & 7.16 & NS & 7.14 \\
\hline $07 / 15 / 2009$ & 6.78 & 6.05 & 6.52 & 6.50 & 6.30 & NS & 6.01 \\
\hline $07 / 29 / 2009$ & 7.13 & 6.89 & NS & NS & NS & NS & NS \\
\hline 08/12/2009 & 6.77 & 6.30 & 6.17 & 6.70 & NS & NS & 6.64 \\
\hline 08/26/2009 & 6.97 & 7.10 & 6.77 & NS & 6.76 & 6.89 & NS \\
\hline 09/09/2009 & 6.60 & NS & 6.18 & NS & 6.23 & NA & NS \\
\hline $10 / 07 / 2009$ & 7.01 & 6.15 & NS & NS & NS & NA & 6.56 \\
\hline $10 / 21 / 2009$ & 6.27 & 5.81 & NS & NS & NS & NS & 6.03 \\
\hline $11 / 04 / 2009$ & NS & 6.61 & NS & NS & 8.20 & NS & NS \\
\hline $11 / 18 / 2009$ & 6.36 & 6.05 & NS & 6.29 & 6.44 & 6.97 & 7.04 \\
\hline $12 / 02 / 2009$ & 6.36 & 5.94 & NS & 6.00 & 6.17 & NS & NS \\
\hline $12 / 16 / 2009$ & 6.45 & 6.30 & 6.74 & 6.59 & 6.44 & NS & 6.49 \\
\hline $12 / 30 / 2009$ & 6.69 & 6.73 & 7.07 & 6.43 & 6.66 & 6.78 & 6.85 \\
\hline 01/13/2010 & 6.66 & 6.62 & NS & NS & 6.76 & NS & NS \\
\hline 01/27/2010 & 6.57 & 6.38 & 6.66 & 6.56 & 6.61 & 6.84 & 6.56 \\
\hline 02/10/2009 & 6.69 & 6.58 & 6.6 & NS & 6.83 & NS & 6.79 \\
\hline 02/24/2010 & NS & 6.52 & 7.14 & NS & 6.48 & 6.93 & 7.15 \\
\hline 03/10/2010 & NS & NS & NS & NS & NS & NS & NS \\
\hline $03 / 24 / 2010$ & NS & 6.98 & 7.05 & 7.03 & 6.78 & 6.92 & 7.06 \\
\hline 04/07/2010 & 6.68 & 6.65 & NS & 6.66 & 6.90 & NS & 6.82 \\
\hline 06/17/2010 & 6.71 & 6.98 & 7.01 & 6.78 & 6.70 & 6.79 & 6.71 \\
\hline
\end{tabular}

NS $=$ no sample 


\section{Aqueous Samples - TSS}

Table A3. Total suspended solids (TSS) values of leachate and runoff (ppm).

\begin{tabular}{|c|c|c|c|c|c|c|c|}
\hline \multirow[b]{2}{*}{ Sample date } & \multicolumn{2}{|l|}{ Control } & \multicolumn{2}{|c|}{$5 \%$ TRAPPS ${ }^{\text {TM }}$} & \multirow{2}{*}{\begin{tabular}{|l|} 
Left $5 \%$ \\
TRAPPS \\
leachate
\end{tabular}} & \multirow{2}{*}{\begin{tabular}{|l}
$\begin{array}{l}\text { Left } 5 \% \\
\text { TTF }\end{array}$ \\
leachate
\end{tabular}} & \multirow{2}{*}{\begin{tabular}{|l|}
$\begin{array}{l}5 \% \text { TRAPPS } \\
+5 \% \text { TTF }\end{array}$ \\
runoff \\
\end{tabular}} \\
\hline & leachate & runoff & leachate & runoff & & & \\
\hline $04 / 08 / 2009$ & 73.00 & 38.00 & 33.00 & 235.00 & 29.00 & 14.00 & 31.00 \\
\hline $04 / 22 / 2009$ & 69.00 & 25.50 & 9.00 & 172.00 & NS & NS & 10.00 \\
\hline $05 / 20 / 2009$ & 120.00 & 50.00 & 40.00 & 200.00 & 50.00 & 40.00 & 60.00 \\
\hline $06 / 03 / 2009$ & 160.00 & 51.00 & 20.00 & 70.00 & 10.00 & 5.00 & 20.00 \\
\hline $06 / 17 / 2009$ & 159.50 & 10.50 & 21.00 & 51.50 & 9.00 & 17.00 & 763.00 \\
\hline $07 / 01 / 2009$ & 3.00 & 66.00 & NS & NS & 2.50 & NS & 108.50 \\
\hline 07/15/2009 & 18.00 & 84.50 & 175.00 & NS & 23.50 & NS & 38.50 \\
\hline $07 / 29 / 2009$ & 32.50 & 39.00 & NS & NS & NS & NS & NS \\
\hline $08 / 12 / 2009$ & 54.00 & 20.00 & 7.00 & 234.50 & NS & NS & 2.50 \\
\hline $08 / 26 / 2009$ & 36.50 & 47.00 & 45.50 & NS & 11.50 & 45.00 & NS \\
\hline 09/09/2009 & 47.00 & 15.00 & 0.50 & NS & 0.50 & NES & NS \\
\hline $10 / 07 / 2009$ & 20.00 & 35.00 & NS & NS & NS & 33.00 & NES \\
\hline $10 / 21 / 2009$ & 45.00 & 5.00 & NS & NS & NS & NS & 5.00 \\
\hline $11 / 04 / 2009$ & NS & NES & NS & NS & NES & NS & NS \\
\hline $11 / 18 / 2009$ & 65.00 & 15.00 & NS & 5.00 & 5.00 & 5.00 & 5.00 \\
\hline $12 / 02 / 2009$ & 6.00 & 29.00 & NS & 28.00 & 27.00 & NS & NS \\
\hline $12 / 16 / 2009$ & 45.00 & 135.00 & 10.00 & 30.00 & 11.00 & NS & 1070 \\
\hline $12 / 30 / 2009$ & 5.00 & 135.00 & 30.00 & 925.00 & 20.00 & 19.50 & 20.00 \\
\hline $01 / 13 / 2010$ & 30.00 & 20.00 & NS & NS & 54.00 & NS & NS \\
\hline $01 / 27 / 2010$ & 220.00 & 315.00 & 5350.00 & 2710 & 2210 & 1210.00 & 30.00 \\
\hline $02 / 10 / 2009$ & 10.00 & 160.00 & 360.00 & NS & 1190.00 & NS & 670.00 \\
\hline $02 / 24 / 2010$ & NS & 15.00 & 605.00 & NS & 415.00 & 280 & 25.00 \\
\hline 03/10/2010 & NS & NS & NS & NS & NS & NS & NS \\
\hline $03 / 24 / 2010$ & NS & 1190 & 74510.00 & 450.00 & 2140 & 2610 & 20.00 \\
\hline $04 / 07 / 2010$ & 70.00 & 270.00 & NS & 310.00 & 790 & NS & 10.00 \\
\hline $06 / 17 / 2010$ & 78.50 & 101.00 & 30519.50 & 2202.5 & 827 & 643.50 & 4.50 \\
\hline
\end{tabular}

$\mathrm{ND}=$ non-detect. The detection limit is $0.025 \mathrm{mg} / \mathrm{L}$ except for $\mathrm{P}$. *the detection limit for $\mathrm{P}$ is $5.0 \mathrm{mg} / \mathrm{L}$.

NS=no sample 


\section{Aqueous Samples - Metal Concentrations}

Table A4. Digested metal concentration in leachate for control lysimeter (ppm).

\begin{tabular}{|c|c|c|c|c|c|c|c|c|c|}
\hline Sample date & $\mathrm{Pb}$ & $\mathrm{Cr}$ & $\mathrm{Ni}$ & $\mathrm{Zn}$ & $\mathrm{Fe}$ & $\mathrm{Mn}$ & $\mathrm{Cu}$ & $\mathrm{Sb}$ & *P \\
\hline $04 / 08 / 2009$ & ND & ND & ND & ND & 0.62 & ND & ND & ND & ND \\
\hline $04 / 22 / 2009$ & ND & ND & ND & 0.06 & 2.16 & ND & ND & ND & ND \\
\hline $05 / 20 / 2009$ & ND & ND & ND & ND & 0.69 & ND & 0.50 & ND & ND \\
\hline $06 / 03 / 2009$ & ND & ND & ND & ND & 0.98 & ND & ND & ND & ND \\
\hline $06 / 17 / 2009$ & ND & ND & ND & ND & 0.65 & ND & ND & ND & ND \\
\hline 07/01/2009 & ND & ND & ND & 0.06 & 0.31 & ND & ND & ND & ND \\
\hline $07 / 15 / 2009$ & ND & ND & ND & ND & 0.43 & ND & ND & 0.06 & ND \\
\hline $07 / 29 / 2009$ & ND & NA & NA & NA & 0.60 & ND & ND & ND & ND \\
\hline $08 / 12 / 2009$ & ND & ND & ND & ND & 0.35 & ND & ND & 0.07 & ND \\
\hline $08 / 26 / 2009$ & ND & ND & ND & ND & 0.42 & ND & ND & 0.09 & ND \\
\hline 09/09/2009 & NA & ND & ND & ND & 0.39 & ND & ND & 0.20 & NA \\
\hline $10 / 07 / 2009$ & ND & ND & ND & ND & ND & ND & 0.06 & 0.21 & ND \\
\hline $10 / 21 / 2009$ & 0.05 & ND & ND & ND & 0.06 & ND & NS & ND & ND \\
\hline $11 / 04 / 2009$ & NS & NS & NS & NS & NS & NS & ND & NS & NS \\
\hline $11 / 18 / 2009$ & ND & ND & ND & ND & ND & ND & 0.36 & 0.11 & ND \\
\hline $12 / 02 / 2009$ & ND & ND & ND & ND & 0.36 & ND & NA & 0.15 & ND \\
\hline $12 / 16 / 2009$ & 0.07 & NS & NA & NS & NA & ND & 0.03 & NA & ND \\
\hline $12 / 30 / 2009$ & 0.03 & ND & ND & ND & 0.07 & NA & 0.90 & ND & ND \\
\hline 01/13/2010 & 0.04 & ND & 0.04 & 0.26 & 0.43 & ND & ND & 0.47 & ND \\
\hline $01 / 27 / 2010$ & 0.06 & ND & ND & 0.07 & 1.68 & 0.08 & ND & 0.50 & ND \\
\hline $02 / 10 / 2009$ & NS & NS & NS & 0.08 & 0.12 & ND & NS & 0.90 & ND \\
\hline $02 / 24 / 2010$ & NS & NS & NS & NS & NS & NS & NS & NS & NS \\
\hline 03/10/2010 & NS & NS & NS & NS & NS & NS & NS & NS & NS \\
\hline $03 / 24 / 2010$ & NS & NS & NS & NS & NS & NS & 0.40 & NS & NS \\
\hline $04 / 07 / 2010$ & 0.61 & ND & ND & 0.03 & 0.30 & ND & 0.17 & 0.14 & ND \\
\hline $06 / 17 / 2010$ & 0.43 & NS & NA & NS & 0.43 & ND & NA & 1.23 & ND \\
\hline
\end{tabular}

$\mathrm{ND}=$ non-detect. The detection limit is $0.025 \mathrm{mg} / \mathrm{L}$ except for $\mathrm{P}$. *the detection limit for $\mathrm{P}$ is $5.0 \mathrm{mg} / \mathrm{L}$.

NS=no sample 
Table A5. Digested metal concentration in runoff for control lysimeter (ppm).

\begin{tabular}{|c|c|c|c|c|c|c|c|c|c|}
\hline Sample date & $\mathrm{Pb}$ & $\mathrm{Cr}$ & $\mathrm{Ni}$ & $Z n$ & $\mathrm{Fe}$ & $\mathrm{Mn}$ & $\mathrm{Cu}$ & $\mathrm{Sb}$ & *P \\
\hline 04/08/2009 & ND & ND & ND & ND & 1.33 & ND & ND & 0.09 & ND \\
\hline $04 / 22 / 2009$ & ND & ND & ND & ND & 1.67 & ND & ND & ND & ND \\
\hline $05 / 20 / 2009$ & ND & ND & ND & ND & 0.21 & ND & 0.08 & ND & ND \\
\hline 06/03/2009 & ND & ND & ND & ND & 0.22 & ND & 1.12 & ND & ND \\
\hline $06 / 17 / 2009$ & ND & ND & ND & ND & 0.27 & ND & 0.09 & ND & ND \\
\hline 07/01/2009 & ND & ND & NS & 0.06 & 0.36 & NS & ND & 0.08 & ND \\
\hline $07 / 15 / 2009$ & ND & NS & ND & ND & 0.54 & ND & ND & ND & ND \\
\hline $07 / 29 / 2009$ & ND & $N D$ & ND & ND & 0.62 & ND & ND & ND & ND \\
\hline $08 / 12 / 2009$ & ND & NS & ND & ND & 1.40 & ND & ND & ND & ND \\
\hline $08 / 26 / 2009$ & 0.16 & ND & NS & ND & 0.51 & NS & ND & ND & ND \\
\hline 09/09/2009 & ND & NS & NS & 0.10 & 0.54 & NS & 0.10 & ND & ND \\
\hline $10 / 07 / 2009$ & 0.23 & NS & ND & 0.14 & 0.74 & ND & 0.38 & 0.61 & 16.22 \\
\hline $10 / 21 / 2009$ & ND & ND & NS & ND & 0.19 & ND & ND & 0.40 & ND \\
\hline $11 / 04 / 2009$ & ND & NS & ND & 0.04 & 0.14 & ND & 0.11 & 0.04 & ND \\
\hline $11 / 18 / 2009$ & ND & ND & ND & 0.10 & 0.13 & ND & 0.15 & 0.06 & ND \\
\hline $12 / 02 / 2009$ & 0.03 & ND & NS & 0.21 & 0.09 & ND & 0.32 & ND & ND \\
\hline $12 / 16 / 2009$ & NS & NS & NA & ND & 4.97 & NS & 0.09 & 0.16 & ND \\
\hline $12 / 30 / 2009$ & 0.68 & NS & ND & 0.26 & 0.74 & ND & 0.55 & 0.11 & ND \\
\hline 01/13/2010 & 0.37 & ND & & 0.33 & 0.70 & ND & 0.94 & 0.22 & ND \\
\hline $01 / 27 / 2010$ & 1.77 & ND & ND & 0.29 & 1.68 & ND & 0.94 & 1.81 & ND \\
\hline $02 / 10 / 2009$ & 2.25 & ND & ND & 0.29 & 1.06 & ND & 0.87 & 0.52 & ND \\
\hline $02 / 24 / 2010$ & 0.50 & $N D$ & NS & 0.06 & 0.21 & ND & 0.30 & NS & ND \\
\hline 03/10/2010 & NS & NS & NS & NS & NS & ND & NS & NS & NS \\
\hline $03 / 24 / 2010$ & 2.49 & NS & ND & 0.11 & 0.97 & ND & 1.66 & 2.24 & ND \\
\hline $04 / 07 / 2010$ & 1.56 & ND & ND & 0.06 & 0.92 & ND & 0.54 & 0.29 & ND \\
\hline $06 / 17 / 2010$ & 4.31 & ND & NA & 1.39 & 0.46 & ND & 2.03 & 4.49 & ND \\
\hline
\end{tabular}

$\mathrm{ND}=$ non-detect. The detection limit is $0.025 \mathrm{mg} / \mathrm{L}$ except for $\mathrm{P}$. *the detection limit for $\mathrm{P}$ is $5.0 \mathrm{mg} / \mathrm{L}$.

NS=no sample 
Table A6. Digested metal concentration in leachate for $7.62 \mathrm{~mm}$ lysimeter (ppm).

\begin{tabular}{|c|c|c|c|c|c|c|c|c|c|}
\hline Sample date & $\mathrm{Pb}$ & $\mathrm{Cr}$ & $\mathrm{Ni}$ & $Z n$ & $\mathrm{Fe}$ & $\mathrm{Mn}$ & $\mathrm{Cu}$ & $\mathrm{Sb}$ & *P \\
\hline 04/08/2009 & ND & ND & ND & 0.08 & 0.08 & ND & ND & ND & 88.26 \\
\hline $04 / 22 / 2009$ & ND & ND & ND & 121.4 & 0.46 & ND & ND & ND & 16.67 \\
\hline $05 / 20 / 2009$ & ND & ND & ND & ND & 0.09 & ND & ND & ND & 113.20 \\
\hline 06/03/2009 & ND & NS & ND & ND & 0.27 & ND & 0.46 & ND & 41.62 \\
\hline $06 / 17 / 2009$ & NS & ND & ND & ND & 0.30 & ND & ND & ND & 123.41 \\
\hline 07/01/2009 & ND & NS & NS & NS & NS & ND & NS & NS & NS \\
\hline $07 / 15 / 2009$ & NS & ND & ND & 0.12 & 0.19 & ND & ND & ND & 107.08 \\
\hline $07 / 29 / 2009$ & ND & NS & NS & NS & NS & ND & NS & NS & NS \\
\hline $08 / 12 / 2009$ & NS & ND & ND & ND & 0.21 & NS & ND & ND & 117.34 \\
\hline $08 / 26 / 2009$ & ND & ND & ND & 0.15 & 0.05 & ND & 0.43 & ND & 114.21 \\
\hline 09/09/2009 & ND & ND & ND & ND & 0.12 & ND & ND & ND & 59.50 \\
\hline $10 / 07 / 2009$ & ND & NS & NS & NS & NS & NS & NS & NS & NS \\
\hline $10 / 21 / 2009$ & NS & NS & NS & NS & NS & NS & NS & NS & NS \\
\hline $11 / 04 / 2009$ & NS & NS & NS & NS & NS & NS & NS & NS & NS \\
\hline $11 / 18 / 2009$ & NS & NS & NS & NS & NS & NS & NS & NS & NS \\
\hline $12 / 02 / 2009$ & NS & NS & NS & NS & NS & NS & NS & NS & NS \\
\hline $12 / 16 / 2009$ & 0.27 & ND & ND & 0.10 & 2.20 & NS & 0.10 & 0.09 & 64.42 \\
\hline $12 / 30 / 2009$ & 0.12 & ND & ND & 0.15 & 0.72 & ND & 0.06 & 0.11 & 54.29 \\
\hline $01 / 13 / 2010$ & NS & NS & NS & NS & NS & NS & NS & NS & NS \\
\hline $01 / 27 / 2010$ & 70.05 & 0.07 & 0.07 & 1.91 & 37.59 & 0.28 & 13.80 & 1.55 & 71.26 \\
\hline $02 / 10 / 2009$ & 6.43 & ND & ND & 0.34 & 4.20 & 0.04 & 1.43 & 0.42 & 17.34 \\
\hline $02 / 24 / 2010$ & 8.98 & ND & ND & 0.51 & 4.88 & 0.06 & 2.02 & 0.81 & 24.10 \\
\hline 03/10/2010 & NS & NS & ND & NS & NS & NS & NS & NS & NS \\
\hline $03 / 24 / 2010$ & 0.08 & 0.68 & 0.55 & 38.75 & 356.40 & 3.24 & 393.20 & 19.59 & 14.43 \\
\hline $04 / 07 / 2010$ & NS & NS & NS & NS & NS & NS & NS & NS & NS \\
\hline $06 / 17 / 2010$ & 715.95 & 0.12 & 0.12 & 12.81 & 80.33 & 0.66 & 112.00 & 13.23 & 107.30 \\
\hline
\end{tabular}

$\mathrm{ND}=$ non-detect. The detection limit is $0.025 \mathrm{mg} / \mathrm{L}$ except for $\mathrm{P}$. *the detection limit for $\mathrm{P}$ is $5.0 \mathrm{mg} / \mathrm{L}$.

NS=no sample 
Table A7. Digested metal concentration in runoff for $7.62 \mathrm{~mm}$ lysimeter (ppm).

\begin{tabular}{|c|c|c|c|c|c|c|c|c|c|}
\hline Sample date & $\mathrm{Pb}$ & $\mathrm{Cr}$ & $\mathrm{Ni}$ & $\mathrm{Zn}$ & $\mathrm{Fe}$ & $\mathrm{Mn}$ & $\mathrm{Cu}$ & $\mathrm{Sb}$ & *P \\
\hline 04/08/2009 & ND & ND & ND & 0.19 & 2.49 & ND & 0.23 & ND & ND \\
\hline $04 / 22 / 2009$ & ND & ND & ND & ND & 1.01 & ND & ND & ND & ND \\
\hline $05 / 20 / 2009$ & 0.11 & ND & ND & ND & 1.19 & ND & 0.10 & ND & ND \\
\hline 06/03/2009 & 0.08 & ND & ND & ND & 1.08 & ND & 1.09 & ND & ND \\
\hline $06 / 17 / 2009$ & ND & ND & ND & ND & 0.71 & ND & 0.05 & ND & ND \\
\hline 07/01/2009 & NS & NS & NS & NS & NS & NS & NS & NS & NS \\
\hline $07 / 15 / 2009$ & ND & ND & ND & ND & 0.19 & ND & ND & ND & ND \\
\hline $07 / 29 / 2009$ & NS & NS & NS & NS & NS & NS & NS & NS & NS \\
\hline $08 / 12 / 2009$ & 2.03 & ND & ND & 0.14 & 6.97 & ND & 0.63 & 0.08 & ND \\
\hline $08 / 26 / 2009$ & NS & NS & NS & NS & NS & NS & NS & NS & NS \\
\hline 09/09/2009 & NS & NS & NS & NS & NS & NS & NS & NS & NS \\
\hline $10 / 07 / 2009$ & NS & NS & NS & NS & NS & NS & NS & NS & NS \\
\hline $10 / 21 / 2009$ & NS & NS & NS & NS & NS & NS & NS & NS & NS \\
\hline $11 / 04 / 2009$ & NS & NS & NS & NS & NS & NS & NS & NS & NS \\
\hline $11 / 18 / 2009$ & ND & ND & ND & ND & 0.23 & ND & 0.16 & 0.06 & ND \\
\hline $12 / 02 / 2009$ & 0.05 & ND & ND & 0.31 & 0.13 & ND & 0.49 & 0.03 & 6.16 \\
\hline $12 / 16 / 2009$ & 0.39 & ND & ND & 0.07 & 1.09 & ND & 0.19 & ND & 8.09 \\
\hline $12 / 30 / 2009$ & 14.56 & ND & ND & 0.53 & 0.37 & 0.15 & 2.86 & 0.43 & 29.17 \\
\hline 01/13/2010 & NS & ND & NS & NS & NS & NS & NS & NS & NS \\
\hline $01 / 27 / 2010$ & 45.54 & 0.10 & 0.08 & 1.42 & 49.73 & 0.41 & 9.34 & 1.35 & 47.60 \\
\hline 02/10/2009 & NS & NS & NS & NS & NS & NS & NS & NS & NS \\
\hline $02 / 24 / 2010$ & NS & NS & NS & NS & NS & NS & NS & NS & NS \\
\hline 03/10/2010 & NS & NS & NS & NS & NS & NS & NS & NS & NS \\
\hline 03/24/2010 & 19.22 & ND & ND & 0.61 & 17.53 & 0.14 & 3.94 & 1.79 & 12.58 \\
\hline 04/07/2010 & 0.65 & ND & ND & ND & 1.03 & 0.05 & 0.38 & 0.16 & ND \\
\hline $06 / 17 / 2010$ & 63.95 & 0.07 & 0.07 & 1.70 & 33.61 & 0.32 & 11.87 & 3.37 & 53.56 \\
\hline
\end{tabular}

$\mathrm{ND}=$ non-detect. The detection limit is $0.025 \mathrm{mg} / \mathrm{L}$ except for $\mathrm{P}$. *the detection limit for $\mathrm{P}$ is $5.0 \mathrm{mg} / \mathrm{L}$.

NS=no sample 
Table A8. Digested metal concentration in leachate for $5 \%$ TTF (ppm).

\begin{tabular}{|c|c|c|c|c|c|c|c|c|c|}
\hline Sample date & $\mathrm{Pb}$ & $\mathrm{Cr}$ & $\mathrm{Ni}$ & $Z n$ & $\mathrm{Fe}$ & $M n$ & $\mathrm{Cu}$ & $\mathrm{Sb}$ & *P \\
\hline 04/08/2009 & ND & ND & ND & ND & 10.41 & ND & ND & ND & 50.62 \\
\hline $04 / 22 / 2009$ & NS & NS & NS & NS & NS & NS & NS & ND & NS \\
\hline $05 / 20 / 2009$ & 0.11 & ND & ND & 0.07 & 0.47 & ND & ND & ND & 55.30 \\
\hline 06/03/2009 & ND & ND & ND & ND & 0.15 & ND & 0.61 & ND & 42.68 \\
\hline $06 / 17 / 2009$ & 0.57 & ND & ND & ND & 0.20 & ND & ND & ND & 23.78 \\
\hline 07/01/2009 & NS & NS & NS & NS & NS & NS & NS & NS & NS \\
\hline $07 / 15 / 2009$ & NS & NS & NS & NS & NS & NS & NS & NS & NS \\
\hline $07 / 29 / 2009$ & NS & NS & NS & NS & NS & NS & NS & NS & NS \\
\hline $08 / 12 / 2009$ & NS & NS & NS & NS & NS & NS & NS & NS & NS \\
\hline $08 / 26 / 2009$ & 0.11 & ND & ND & 0.07 & 0.51 & NS & ND & ND & 50.03 \\
\hline 09/09/2009 & NS & NS & NS & NS & NS & NS & NS & NS & NS \\
\hline $10 / 07 / 2009$ & ND & ND & ND & ND & 0.07 & NS & 0.07 & ND & 5.05 \\
\hline $10 / 21 / 2009$ & NS & NS & NS & NS & NS & ND & NS & NS & NS \\
\hline $11 / 04 / 2009$ & NS & NS & NS & NS & NS & NS & NS & NS & NS \\
\hline $11 / 18 / 2009$ & ND & ND & ND & ND & ND & ND & ND & ND & 36.34 \\
\hline $12 / 02 / 2009$ & NS & NS & NS & NS & NS & NS & NS & NS & NS \\
\hline $12 / 16 / 2009$ & NS & NS & NS & NS & NS & NS & NS & NS & NS \\
\hline $12 / 30 / 2009$ & 0.36 & ND & ND & ND & 0.53 & ND & 0.07 & 0.06 & 35.17 \\
\hline $01 / 13 / 2010$ & NS & NS & NS & NS & NS & NS & NS & NS & NS \\
\hline $01 / 27 / 2010$ & 18.14 & ND & 0.03 & 0.57 & 13.13 & 0.24 & 3.49 & 0.40 & 53.48 \\
\hline $02 / 10 / 2009$ & NS & NS & NS & NS & NS & NS & NS & NS & NS \\
\hline $02 / 24 / 2010$ & 3.93 & ND & ND & 0.22 & 3.17 & ND & 0.84 & 0.26 & 27.23 \\
\hline 03/10/2010 & NS & NS & NS & NS & NS & NS & NS & NS & NS \\
\hline $03 / 24 / 2010$ & 44.75 & 0.03 & 0.05 & 1.18 & 18.96 & 0.19 & 8.80 & 0.98 & 18.51 \\
\hline $04 / 07 / 2010$ & NS & NS & NS & NS & NS & NS & NS & NS & NS \\
\hline $06 / 17 / 2010$ & 8.18 & ND & ND & 0.34 & 2.76 & ND & 1.77 & 0.19 & 64.37 \\
\hline
\end{tabular}

$\mathrm{ND}=$ non-detect. The detection limit is $0.025 \mathrm{mg} / \mathrm{L}$ except for $\mathrm{P}$. *the detection limit for $\mathrm{P}$ is $5.0 \mathrm{mg} / \mathrm{L}$.

NS=no sample 
Table A9. Digested metal concentration in leachate for $5 \%$ TRAPPS $^{\mathrm{TM}}(\mathrm{ppm})$.

\begin{tabular}{|c|c|c|c|c|c|c|c|c|c|}
\hline Sample date & $\mathrm{Pb}$ & $\mathrm{Cr}$ & $\mathrm{Ni}$ & $\mathrm{Zn}$ & $\mathrm{Fe}$ & $\mathrm{Mn}$ & $\mathrm{Cu}$ & $\mathrm{Sb}$ & *P \\
\hline 04/08/2009 & ND & ND & ND & ND & 1.93 & ND & 0.11 & ND & ND \\
\hline $04 / 22 / 2009$ & NS & NS & NS & NS & NS & ND & NS & ND & NS \\
\hline $05 / 20 / 2009$ & ND & ND & ND & ND & 0.19 & ND & ND & ND & 50.19 \\
\hline 06/03/2009 & ND & ND & ND & ND & ND & ND & 0.35 & ND & 49.42 \\
\hline 06/17/2009 & ND & ND & ND & ND & 0.11 & ND & ND & ND & 53.70 \\
\hline 07/01/2009 & ND & ND & ND & 0.15 & 0.09 & ND & ND & ND & 47.05 \\
\hline 07/15/2009 & ND & ND & ND & 0.09 & 0.32 & ND & ND & ND & 38.09 \\
\hline $07 / 29 / 2009$ & NS & NS & NS & NS & NS & NS & NS & NS & NS \\
\hline $08 / 12 / 2009$ & NS & NS & NS & NS & NS & NS & NS & NS & NS \\
\hline $08 / 26 / 2009$ & ND & ND & ND & ND & 0.07 & ND & ND & ND & 49.72 \\
\hline 09/09/2009 & ND & ND & ND & ND & ND & NS & ND & ND & 64.67 \\
\hline $10 / 07 / 2009$ & NS & ND & NS & NS & NS & NS & NS & NS & NS \\
\hline $10 / 21 / 2009$ & NS & NS & NS & NS & NS & NS & NS & NS & NS \\
\hline $11 / 04 / 2009$ & ND & NS & ND & ND & 0.03 & ND & ND & ND & ND \\
\hline $11 / 18 / 2009$ & ND & ND & ND & ND & ND & ND & ND & ND & 51.46 \\
\hline $12 / 02 / 2009$ & ND & ND & ND & ND & 0.05 & ND & 0.2166 & ND & 103.60 \\
\hline $12 / 16 / 2009$ & 0.37 & ND & ND & 0.11 & 0.33 & ND & 0.41 & 0.14 & 39.80 \\
\hline $12 / 30 / 2009$ & 0.16 & ND & ND & 0.05 & 0.45 & ND & 0.05 & 0.08 & 23.92 \\
\hline 01/13/2010 & 0.12 & ND & 0.04 & 0.07 & 0.28 & ND & 0.20 & 0.06 & ND \\
\hline $01 / 27 / 2010$ & 32.18 & 0.04 & 0.04 & 0.96 & 23.15 & 0.19 & 6.27 & 0.75 & 46.34 \\
\hline 02/10/2009 & 20.80 & 0.03 & 0.03 & 0.70 & 16.05 & 0.13 & 4.11 & 0.56 & 29.76 \\
\hline 02/24/2010 & 8.53 & ND & 0.03 & 0.77 & 5.68 & 0.05 & 1.73 & 0.27 & 11.22 \\
\hline 03/10/2010 & NS & NS & NS & NS & NS & NS & NS & NS & NS \\
\hline 03/24/2010 & 78.41 & 0.06 & 0.06 & 1.98 & 35.08 & 0.32 & 78.41 & 1.51 & 22.46 \\
\hline 04/07/2010 & ND & ND & ND & ND & ND & ND & ND & ND & 20.27 \\
\hline $06 / 17 / 2010$ & 16.91 & ND & 0.03 & 0.43 & 8.12 & 0.08 & 3.01 & 0.47 & 93.80 \\
\hline
\end{tabular}

$\mathrm{ND}=$ non-detect. The detection limit is $0.025 \mathrm{mg} / \mathrm{L}$ except for $\mathrm{P}$. *the detection limit for $\mathrm{P}$ is $5.0 \mathrm{mg} / \mathrm{L}$.

NS=no sample 
Table A10. Digested metal concentration in runoff for Left TRAPPS ${ }^{\mathrm{TM}}$ (ppm).

\begin{tabular}{|c|c|c|c|c|c|c|c|c|c|}
\hline Sample date & $\mathrm{Pb}$ & $\mathrm{Cr}$ & $\mathrm{Ni}$ & $\mathrm{Zn}$ & $\mathrm{Fe}$ & $\mathrm{Mn}$ & $\mathrm{Cu}$ & $\mathrm{Sb}$ & *P \\
\hline 04/08/2009 & ND & ND & ND & 0.06 & 0.10 & ND & ND & ND & 43.37 \\
\hline $04 / 22 / 2009$ & ND & NA & ND & ND & 0.26 & ND & ND & ND & ND \\
\hline $05 / 20 / 2009$ & ND & ND & ND & ND & 0.79 & ND & 0.11 & ND & ND \\
\hline $06 / 03 / 2009$ & ND & ND & ND & ND & 0.37 & ND & 0.48 & ND & ND \\
\hline $06 / 17 / 2009$ & 0.90 & ND & ND & 0.34 & 16.51 & 0.15 & 0.38 & ND & ND \\
\hline 07/01/2009 & 0.21 & ND & ND & 0.19 & 2.98 & 0.07 & 0.13 & ND & ND \\
\hline $07 / 15 / 2009$ & ND & ND & ND & ND & 0.39 & ND & ND & ND & ND \\
\hline $07 / 29 / 2009$ & NS & NS & NS & NS & NS & NS & NS & NS & NS \\
\hline $08 / 12 / 2009$ & ND & ND & ND & ND & 0.50 & 1.04 & 0.08 & ND & ND \\
\hline $08 / 26 / 2009$ & NS & ND & NS & NS & NS & NS & NS & NS & NS \\
\hline $09 / 09 / 2009$ & NS & NS & NS & NS & NS & NS & NS & NS & NS \\
\hline $10 / 07 / 2009$ & ND & NS & ND & ND & 0.12 & ND & 0.07 & 0.03 & 11.29 \\
\hline $10 / 21 / 2009$ & 0.07 & ND & ND & 0.05 & 0.21 & ND & 0.08 & ND & 8.12 \\
\hline $11 / 04 / 2009$ & NS & NS & NS & NS & NS & NS & NS & NS & NS \\
\hline $11 / 18 / 2009$ & NS & NS & NS & 0.03 & 0.03 & ND & 0.03 & 0.05 & ND \\
\hline $12 / 02 / 2009$ & NS & NS & NS & NS & NS & NS & NS & NS & NS \\
\hline $12 / 16 / 2009$ & 20.07 & ND & ND & 0.52 & 6.70 & 0.06 & 3.48 & 0.63 & ND \\
\hline $12 / 30 / 2009$ & 0.34 & ND & ND & 0.03 & 0.50 & 0.13 & 0.13 & 0.24 & ND \\
\hline $01 / 13 / 2010$ & NS & NS & NS & NS & NS & NS & NS & NS & NS \\
\hline $01 / 27 / 2010$ & 2.19 & ND & ND & 0.16 & 0.47 & ND & 0.55 & 0.28 & ND \\
\hline $02 / 10 / 2009$ & 12.03 & ND & ND & 0.38 & 5.11 & 0.04 & 2.29 & 1.11 & ND \\
\hline $02 / 24 / 2010$ & 0.87 & ND & ND & 0.05 & 5.68 & ND & 0.26 & 0.81 & ND \\
\hline 03/10/2010 & NS & NS & NS & NS & NS & NS & NS & NS & NS \\
\hline $03 / 24 / 2010$ & 0.38 & ND & ND & 0.03 & 0.24 & ND & 0.15 & 0.94 & ND \\
\hline 04/07/2010 & 5.90 & ND & ND & 0.10 & 5.19 & 0.04 & 1.62 & 0.14 & ND \\
\hline $06 / 17 / 2010$ & 1.22 & ND & ND & 0.09 & 0.52 & 0.01 & 0.37 & 1.19 & 7.07 \\
\hline
\end{tabular}

$\mathrm{ND}=$ non-detect. The detection limit is $0.025 \mathrm{mg} / \mathrm{L}$ except for $\mathrm{P}$. *the detection limit for $\mathrm{P}$ is $5.0 \mathrm{mg} / \mathrm{L}$.

NS=no sample 
Table A11. Soluble metal concentration in leachate for control lysimeter (ppm).

\begin{tabular}{|c|c|c|c|c|c|c|c|c|c|}
\hline Sample date & $\mathrm{Pb}$ & $\mathrm{Cr}$ & $\mathrm{Ni}$ & $\mathrm{Zn}$ & $\mathrm{Fe}$ & $\mathrm{Mn}$ & $\mathrm{Cu}$ & $\mathrm{Sb}$ & *P \\
\hline $04 / 08 / 2009$ & ND & ND & ND & ND & 0.03 & ND & ND & 0.05 & ND \\
\hline $04 / 22 / 2009$ & ND & ND & ND & ND & 0.04 & ND & ND & ND & ND \\
\hline $05 / 20 / 2009$ & ND & ND & ND & ND & 0.05 & ND & ND & 0.03 & ND \\
\hline 06/03/2009 & ND & ND & ND & ND & ND & ND & 0.50 & 0.05 & ND \\
\hline $06 / 17 / 2009$ & ND & ND & ND & ND & ND & ND & ND & 0.06 & ND \\
\hline $07 / 01 / 2009$ & ND & $N D$ & $N D$ & ND & 0.15 & ND & ND & ND & ND \\
\hline $07 / 15 / 2009$ & ND & ND & ND & ND & 0.04 & ND & ND & 0.04 & ND \\
\hline $07 / 29 / 2009$ & ND & ND & ND & ND & ND & ND & ND & 0.05 & ND \\
\hline $08 / 12 / 2009$ & ND & $N D$ & $N D$ & ND & 0.04 & ND & ND & 0.09 & ND \\
\hline $08 / 26 / 2009$ & ND & ND & ND & ND & 0.06 & ND & ND & 0.11 & ND \\
\hline 09/09/2009 & ND & ND & ND & ND & 0.03 & ND & ND & 0.24 & ND \\
\hline $10 / 07 / 2009$ & ND & $N D$ & $N D$ & 0.08 & ND & ND & ND & 0.04 & ND \\
\hline $10 / 21 / 2009$ & ND & ND & ND & ND & ND & ND & 0.06 & 0.15 & ND \\
\hline $11 / 04 / 2009$ & NS & NS & NS & NS & NS & NS & NS & NS & NS \\
\hline $11 / 18 / 2009$ & ND & $N D$ & $N D$ & ND & ND & ND & ND & 0.12 & ND \\
\hline $12 / 02 / 2009$ & ND & ND & ND & ND & 0.04 & ND & 0.36 & 0.14 & ND \\
\hline $12 / 16 / 2009$ & ND & ND & ND & ND & ND & ND & 0.05 & 0.34 & ND \\
\hline $12 / 30 / 2009$ & ND & ND & ND & ND & ND & ND & 0.03 & 0.35 & ND \\
\hline 01/13/2010 & ND & $N D$ & $N D$ & ND & ND & ND & 0.90 & 0.49 & ND \\
\hline $01 / 27 / 2010$ & ND & ND & $N D$ & ND & ND & ND & ND & 0.69 & ND \\
\hline $02 / 10 / 2009$ & NS & NS & NS & ND & ND & ND & ND & 1.08 & ND \\
\hline $02 / 24 / 2010$ & NS & NS & NS & NS & NS & NS & NS & NS & NS \\
\hline $03 / 10 / 2010$ & NS & NS & NS & NS & NS & NS & NS & NS & NS \\
\hline 03/24/2010 & NS & NS & NS & NS & NS & NS & NS & NS & NS \\
\hline $04 / 07 / 2010$ & 0.06 & ND & ND & ND & ND & ND & 0.40 & 0.92 & ND \\
\hline $06 / 17 / 2010$ & ND & ND & ND & ND & ND & ND & 0.17 & 1.43 & ND \\
\hline
\end{tabular}

$\mathrm{ND}=$ non-detect. The detection limit is $0.025 \mathrm{mg} / \mathrm{L}$ except for $\mathrm{P}$. *the detection limit for $\mathrm{P}$ is $5.0 \mathrm{mg} / \mathrm{L}$.

NS=no sample 
Table A12. Soluble metal concentration in runoff for control lysimeter (ppm).

\begin{tabular}{|c|c|c|c|c|c|c|c|c|c|}
\hline Sample date & $\mathrm{Pb}$ & $\mathrm{Cr}$ & $\mathrm{Ni}$ & $Z n$ & $\mathrm{Fe}$ & $\mathrm{Mn}$ & $\mathrm{Cu}$ & $\mathrm{Sb}$ & *P \\
\hline 04/08/2009 & ND & ND & ND & 0.05 & 0.67 & ND & 0.06 & 0.10 & ND \\
\hline $04 / 22 / 2009$ & ND & ND & ND & ND & 0.69 & ND & ND & 0.06 & ND \\
\hline $05 / 20 / 2009$ & ND & ND & ND & ND & 0.34 & ND & 0.08 & 0.08 & ND \\
\hline 06/03/2009 & ND & ND & ND & ND & 0.12 & ND & ND & ND & ND \\
\hline $06 / 17 / 2009$ & ND & ND & ND & ND & 0.19 & ND & ND & ND & ND \\
\hline 07/01/2009 & ND & ND & ND & ND & 0.06 & ND & ND & 0.06 & ND \\
\hline $07 / 15 / 2009$ & ND & ND & ND & ND & 0.37 & ND & ND & ND & ND \\
\hline $07 / 29 / 2009$ & ND & ND & ND & ND & 0.27 & ND & ND & ND & ND \\
\hline $08 / 12 / 2009$ & ND & ND & ND & ND & 0.91 & ND & 0.08 & ND & ND \\
\hline $08 / 26 / 2009$ & ND & ND & ND & 0.36 & 0.36 & ND & 0.04 & ND & ND \\
\hline 09/09/2009 & ND & ND & ND & 0.28 & 0.28 & ND & 0.03 & ND & ND \\
\hline $10 / 07 / 2009$ & 0.07 & ND & ND & 0.34 & 0.13 & ND & 0.10 & ND & ND \\
\hline $10 / 21 / 2009$ & ND & ND & ND & ND & 0.16 & ND & 0.07 & ND & ND \\
\hline $11 / 04 / 2009$ & 0.04 & ND & $N D$ & ND & 0.12 & ND & 0.10 & 0.03 & ND \\
\hline $11 / 18 / 2009$ & 0.07 & ND & ND & ND & 0.09 & ND & 0.11 & 0.06 & ND \\
\hline $12 / 02 / 2009$ & ND & ND & ND & ND & 0.04 & ND & 0.28 & ND & ND \\
\hline $12 / 16 / 2009$ & 0.09 & ND & ND & ND & 1.67 & ND & 0.10 & 0.09 & ND \\
\hline $12 / 30 / 2009$ & 0.05 & ND & ND & ND & 0.20 & ND & 0.68 & 0.08 & ND \\
\hline $01 / 13 / 2010$ & 0.06 & ND & ND & ND & 0.19 & ND & 0.11 & 0.56 & ND \\
\hline $01 / 27 / 2010$ & 0.52 & ND & ND & 0.07 & 0.15 & ND & 0.53 & 0.90 & ND \\
\hline 02/10/2009 & 1.20 & ND & ND & 0.09 & 0.16 & ND & 0.54 & 1.23 & ND \\
\hline $02 / 24 / 2010$ & 0.14 & ND & ND & ND & 0.21 & ND & 0.25 & 0.57 & ND \\
\hline 03/10/2010 & NS & NS & NS & NS & NS & NS & NS & NS & NS \\
\hline 03/24/2010 & 0.50 & ND & ND & ND & 0.05 & ND & 1.14 & 1.08 & ND \\
\hline $04 / 07 / 2010$ & 0.43 & ND & ND & ND & 0.14 & ND & 0.37 & 0.8 & ND \\
\hline $06 / 17 / 2010$ & 0.73 & ND & ND & 0.14 & 0.06 & 0.02 & 1.62 & 3.18 & ND \\
\hline
\end{tabular}

$\mathrm{ND}=$ non-detect. The detection limit is $0.025 \mathrm{mg} / \mathrm{L}$ except for $\mathrm{P}$. *the detection limit for $\mathrm{P}$ is $5.0 \mathrm{mg} / \mathrm{L}$.

NS=no sample 
Table A13. Soluble metal concentration in leachate for $7.62 \mathrm{~mm}$ lysimeter (ppm).

\begin{tabular}{|c|c|c|c|c|c|c|c|c|c|}
\hline Sample date & $\mathrm{Pb}$ & $\mathrm{Cr}$ & $\mathrm{Ni}$ & $\mathrm{Zn}$ & $\mathrm{Fe}$ & $M n$ & $\mathrm{Cu}$ & $\mathrm{Sb}$ & $* \mathrm{P}$ \\
\hline 04/08/2009 & ND & ND & ND & ND & 0.23 & ND & ND & ND & 92.36 \\
\hline $04 / 22 / 2009$ & ND & ND & ND & ND & ND & ND & ND & ND & 15.65 \\
\hline $05 / 20 / 2009$ & ND & ND & ND & ND & ND & ND & ND & ND & 135.43 \\
\hline 06/03/2009 & ND & ND & ND & ND & ND & ND & 0.46 & ND & 50.02 \\
\hline $06 / 17 / 2009$ & ND & ND & ND & ND & ND & ND & ND & ND & 146.23 \\
\hline 07/01/2009 & NS & NS & NS & NS & NS & NS & NS & NS & NS \\
\hline $07 / 15 / 2009$ & ND & ND & ND & ND & ND & ND & ND & ND & 128.73 \\
\hline $07 / 29 / 2009$ & NS & NS & NS & NS & NS & NS & NS & NS & NS \\
\hline $08 / 12 / 2009$ & ND & ND & ND & ND & ND & ND & ND & ND & 135.29 \\
\hline $08 / 26 / 2009$ & ND & ND & ND & ND & ND & ND & 0.43 & 0.06 & 129.56 \\
\hline 09/09/2009 & ND & ND & ND & ND & ND & ND & ND & ND & 66.73 \\
\hline $10 / 07 / 2009$ & NS & NS & NS & NS & NS & NS & NS & NS & NS \\
\hline $10 / 21 / 2009$ & NS & NS & NS & NS & NS & NS & NS & NS & NS \\
\hline $11 / 04 / 2009$ & NS & NS & NS & NS & NS & NS & NS & NS & NS \\
\hline $11 / 18 / 2009$ & NS & NS & NS & NS & NS & NS & NS & NS & NS \\
\hline $12 / 02 / 2009$ & NS & NS & NS & NS & NS & NS & NS & NS & NS \\
\hline $12 / 16 / 2009$ & ND & ND & ND & ND & ND & ND & 0.10 & 0.07 & 80.27 \\
\hline $12 / 30 / 2009$ & ND & ND & ND & ND & ND & ND & 0.06 & 0.16 & 50.93 \\
\hline 01/13/2010 & NS & NS & NS & NS & NS & NS & NS & NS & NS \\
\hline $01 / 27 / 2010$ & 0.18 & 0.07 & ND & ND & 0.06 & ND & 13.80 & 0.60 & 59.83 \\
\hline $02 / 10 / 2009$ & 0.08 & ND & ND & ND & ND & ND & 1.43 & 0.38 & 13.34 \\
\hline $02 / 24 / 2010$ & 0.05 & ND & ND & ND & ND & ND & 2.02 & 0.86 & 22.34 \\
\hline 03/10/2010 & NS & NS & NS & NS & NS & NS & NS & NS & NS \\
\hline $03 / 24 / 2010$ & 0.09 & 0.68 & ND & ND & ND & ND & 393.20 & 2.00 & 10.51 \\
\hline $04 / 07 / 2010$ & NS & NS & NS & NS & NS & NS & NS & NS & NS \\
\hline $06 / 17 / 2010$ & 1.15 & 0.12 & ND & 0.04 & 0.14 & ND & 112.00 & 5.96 & 48.23 \\
\hline
\end{tabular}

$\mathrm{ND}=$ non-detect. The detection limit is $0.025 \mathrm{mg} / \mathrm{L}$ except for $\mathrm{P}$. *the detection limit for $\mathrm{P}$ is $5.0 \mathrm{mg} / \mathrm{L}$.

NS=no sample 
Table A14. Soluble metal concentration in runoff for $7.62 \mathrm{~mm}$ lysimeter (ppm).

\begin{tabular}{|c|c|c|c|c|c|c|c|c|c|}
\hline Sample date & $\mathrm{Pb}$ & $\mathrm{Cr}$ & $\mathrm{Ni}$ & $\mathrm{Zn}$ & $\mathrm{Fe}$ & $\mathrm{Mn}$ & $\mathrm{Cu}$ & $\mathrm{Sb}$ & *P \\
\hline 04/08/2009 & ND & ND & ND & ND & 0.66 & ND & 0.06 & ND & 10.65 \\
\hline $04 / 22 / 2009$ & ND & ND & ND & ND & 0.19 & ND & ND & ND & ND \\
\hline $05 / 20 / 2009$ & ND & ND & ND & ND & 0.40 & ND & ND & ND & ND \\
\hline 06/03/2009 & ND & ND & ND & ND & 0.15 & ND & ND & ND & ND \\
\hline $06 / 17 / 2009$ & ND & ND & ND & ND & 0.21 & ND & ND & ND & ND \\
\hline $07 / 01 / 2009$ & NS & NS & NS & NS & NS & NS & NS & NS & NS \\
\hline $07 / 15 / 2009$ & ND & ND & ND & ND & 0.07 & ND & ND & ND & ND \\
\hline $07 / 29 / 2009$ & NS & NS & NS & NS & NS & NS & NS & NS & NS \\
\hline $08 / 12 / 2009$ & ND & $N D$ & $N D$ & ND & 0.04 & ND & 0.17 & 0.07 & ND \\
\hline $08 / 26 / 2009$ & NS & NS & NS & NS & NS & NS & NS & NS & NS \\
\hline 09/09/2009 & NS & NS & NS & NS & NS & NS & NS & NS & NS \\
\hline $10 / 07 / 2009$ & NS & NS & NS & NS & NS & NS & NS & NS & NS \\
\hline $10 / 21 / 2009$ & NS & NS & NS & NS & NS & NS & NS & NS & NS \\
\hline $11 / 04 / 2009$ & NS & NS & NS & NS & NS & NS & NS & NS & NS \\
\hline $11 / 18 / 2009$ & 0.06 & $N D$ & $N D$ & ND & ND & ND & 0.11 & 0.05 & ND \\
\hline $12 / 02 / 2009$ & ND & ND & ND & ND & ND & ND & 0.34 & ND & ND \\
\hline $12 / 16 / 2009$ & ND & ND & ND & ND & ND & ND & 0.11 & 0.08 & ND \\
\hline $12 / 30 / 2009$ & 0.13 & ND & ND & ND & 0.08 & ND & 0.26 & 0.33 & 21.85 \\
\hline $01 / 13 / 2010$ & NS & NS & NS & NS & NS & NS & NS & NS & NS \\
\hline $01 / 27 / 2010$ & 0.21 & ND & $N D$ & ND & 0.15 & ND & 0.38 & 0.74 & ND \\
\hline $02 / 10 / 2009$ & NS & NS & NS & NS & NS & NS & NS & NS & NS \\
\hline $02 / 24 / 2010$ & NS & NS & NS & NS & NS & NS & NS & NS & NS \\
\hline $03 / 10 / 2010$ & NS & NS & NS & NS & NS & NS & NS & NS & NS \\
\hline 03/24/2010 & ND & ND & ND & ND & ND & ND & 0.29 & 1.88 & ND \\
\hline 04/07/2010 & 0.17 & ND & ND & ND & 0.09 & ND & 0.36 & 1.55 & ND \\
\hline $06 / 17 / 2010$ & 1.28 & ND & ND & ND & 0.11 & 0.08 & 1.21 & 3.09 & ND \\
\hline
\end{tabular}

$\mathrm{ND}=$ non-detect. The detection limit is $0.025 \mathrm{mg} / \mathrm{L}$ except for $\mathrm{P}$. *the detection limit for $\mathrm{P}$ is $5.0 \mathrm{mg} / \mathrm{L}$.

NS=no sample 
Table A15. Soluble metal concentration in leachate for $5 \%$ TTF (ppm).

\begin{tabular}{|c|c|c|c|c|c|c|c|c|c|}
\hline Sample date & $\mathrm{Pb}$ & $\mathrm{Cr}$ & $\mathrm{Ni}$ & $\mathrm{Zn}$ & $\mathrm{Fe}$ & $\mathrm{Mn}$ & $\mathrm{Cu}$ & $\mathrm{Sb}$ & *P \\
\hline 04/08/2009 & ND & ND & ND & ND & ND & ND & ND & ND & 57.93 \\
\hline $04 / 22 / 2009$ & NS & NS & NS & NS & NS & NS & NS & NS & NS \\
\hline $05 / 20 / 2009$ & ND & ND & ND & ND & ND & ND & ND & ND & 68.48 \\
\hline 06/03/2009 & ND & ND & ND & ND & ND & ND & ND & ND & 50.00 \\
\hline $06 / 17 / 2009$ & ND & ND & ND & ND & ND & ND & ND & ND & 29.73 \\
\hline 07/01/2009 & NS & NS & NS & NS & NS & NS & NS & NS & NS \\
\hline $07 / 15 / 2009$ & NS & NS & NS & NS & NS & NS & NS & NS & NS \\
\hline $07 / 29 / 2009$ & NS & NS & NS & NS & NS & NS & NS & NS & NS \\
\hline $08 / 12 / 2009$ & NS & NS & NS & NS & NS & NS & NS & NS & NS \\
\hline $08 / 26 / 2009$ & ND & ND & ND & ND & ND & ND & ND & ND & 55.25 \\
\hline 09/09/2009 & NS & NS & NS & NS & NS & NS & NS & NS & NS \\
\hline $10 / 07 / 2009$ & 0.04 & ND & ND & 0.47 & ND & ND & 0.26 & ND & 8.20 \\
\hline $10 / 21 / 2009$ & NS & NS & NS & NS & NS & NS & NS & NS & NS \\
\hline $11 / 04 / 2009$ & NS & NS & NS & NS & NS & NS & NS & NS & NS \\
\hline $11 / 18 / 2009$ & ND & ND & ND & ND & ND & ND & ND & ND & 32.84 \\
\hline $12 / 02 / 2009$ & NS & NS & NS & NS & NS & NS & NS & NS & NS \\
\hline $12 / 16 / 2009$ & NS & NS & NS & NS & NS & NS & NS & NS & NS \\
\hline $12 / 30 / 2009$ & ND & ND & ND & ND & ND & ND & ND & 0.05 & 32.53 \\
\hline $01 / 13 / 2010$ & NS & NS & NS & NS & NS & NS & NS & NS & NS \\
\hline $01 / 27 / 2010$ & 0.07 & ND & ND & ND & ND & ND & 0.07 & 0.14 & 49.21 \\
\hline $02 / 10 / 2009$ & NS & NS & NS & NS & NS & NS & NS & NS & NS \\
\hline $02 / 24 / 2010$ & ND & ND & ND & ND & ND & ND & 0.04 & 0.23 & 17.73 \\
\hline 03/10/2010 & NS & NS & NS & NS & NS & NS & NS & NS & NS \\
\hline $03 / 24 / 2010$ & ND & ND & ND & ND & ND & ND & ND & 0.44 & 9.56 \\
\hline $04 / 07 / 2010$ & NS & NS & NS & NS & NS & NS & NS & NS & NS \\
\hline $06 / 17 / 2010$ & ND & ND & ND & ND & ND & ND & 0.09 & 0.06 & 54.78 \\
\hline
\end{tabular}

$\mathrm{ND}=$ non-detect. The detection limit is $0.025 \mathrm{mg} / \mathrm{L}$ except for $\mathrm{P}$. *the detection limit for $\mathrm{P}$ is $5.0 \mathrm{mg} / \mathrm{L}$.

NS=no sample 
Table A16. Soluble metal concentration in leachate for $5 \%$ TRAPPS $^{\mathrm{TM}}(\mathrm{ppm})$.

\begin{tabular}{|c|c|c|c|c|c|c|c|c|c|}
\hline Sample date & $\mathrm{Pb}$ & $\mathrm{Cr}$ & $\mathrm{Ni}$ & $Z n$ & $\mathrm{Fe}$ & $\mathrm{Mn}$ & $\mathrm{Cu}$ & $\mathrm{Sb}$ & *P \\
\hline $04 / 08 / 2009$ & ND & ND & ND & ND & ND & ND & ND & ND & 45.05 \\
\hline $04 / 22 / 2009$ & NS & NS & NS & NS & NS & NS & NS & NS & NS \\
\hline $05 / 20 / 2009$ & ND & ND & ND & ND & ND & ND & ND & ND & 58.64 \\
\hline $06 / 03 / 2009$ & ND & ND & ND & ND & ND & ND & ND & ND & 62.10 \\
\hline $06 / 17 / 2009$ & ND & ND & ND & ND & ND & ND & ND & ND & 58.31 \\
\hline $07 / 01 / 2009$ & ND & ND & ND & ND & ND & ND & ND & ND & 62.15 \\
\hline $07 / 15 / 2009$ & ND & ND & ND & ND & ND & ND & ND & ND & 47.59 \\
\hline $07 / 29 / 2009$ & NS & NS & NS & NS & NS & NS & NS & NS & NS \\
\hline $08 / 12 / 2009$ & NS & NS & NS & NS & NS & NS & NS & NS & NS \\
\hline $08 / 26 / 2009$ & ND & ND & ND & ND & ND & ND & ND & ND & 58.41 \\
\hline 09/09/2009 & ND & ND & ND & ND & ND & ND & ND & ND & 75.18 \\
\hline $10 / 07 / 2009$ & NS & NS & NS & NS & NS & NS & NS & NS & NS \\
\hline $10 / 21 / 2009$ & NS & NS & NS & NS & NS & NS & NS & NS & NS \\
\hline $11 / 04 / 2009$ & ND & ND & ND & ND & ND & ND & ND & ND & ND \\
\hline $11 / 18 / 2009$ & ND & ND & ND & ND & ND & ND & ND & ND & 47.53 \\
\hline $12 / 02 / 2009$ & ND & ND & ND & ND & ND & ND & ND & ND & 17.46 \\
\hline $12 / 16 / 2009$ & ND & ND & ND & ND & ND & ND & ND & 0.03 & 52.01 \\
\hline $12 / 30 / 2009$ & ND & ND & ND & ND & ND & ND & ND & 0.09 & 5.01 \\
\hline $01 / 13 / 2010$ & ND & ND & ND & ND & ND & ND & ND & 0.09 & ND \\
\hline $01 / 27 / 2010$ & 0.07 & ND & ND & ND & ND & ND & ND & 0.32 & 33.02 \\
\hline 02/10/2009 & 0.09 & ND & ND & ND & ND & ND & 0.06 & 0.34 & 14.85 \\
\hline $02 / 24 / 2010$ & 0.05 & ND & ND & 0.09 & ND & ND & 0.07 & 0.21 & ND \\
\hline 03/10/2010 & NS & NS & NS & NS & NS & NS & NS & NS & NS \\
\hline 03/24/2010 & ND & ND & ND & ND & ND & ND & ND & 0.51 & 7.11 \\
\hline 04/07/2010 & 0.05 & ND & ND & ND & 0.04 & ND & ND & 0.59 & 18.41 \\
\hline $06 / 17 / 2010$ & ND & ND & ND & ND & ND & ND & 0.12 & 0.34 & 124.70 \\
\hline
\end{tabular}

$\mathrm{ND}=$ non-detect. The detection limit is $0.025 \mathrm{mg} / \mathrm{L}$ except for $\mathrm{P}$. *the detection limit for $\mathrm{P}$ is $5.0 \mathrm{mg} / \mathrm{L}$.

NS=no sample 
Table A17. Soluble metal concentration in runoff for Left TRAPPS ${ }^{\mathrm{TM}}$ (ppm).

\begin{tabular}{|c|c|c|c|c|c|c|c|c|c|}
\hline Sample date & $\mathrm{Pb}$ & $\mathrm{Cr}$ & $\mathrm{Ni}$ & $Z n$ & $\mathrm{Fe}$ & $\mathrm{Mn}$ & $\mathrm{Cu}$ & $\mathrm{Sb}$ & $* P$ \\
\hline 04/08/2009 & 0.07 & 0.03 & 0.03 & 0.03 & 0.21 & 0.03 & 0.07 & 0.03 & 5.00 \\
\hline $04 / 22 / 2009$ & 0.03 & 0.03 & 0.03 & 0.03 & 0.03 & 0.03 & 0.03 & 0.03 & 5.00 \\
\hline $05 / 20 / 2009$ & 0.06 & 0.03 & 0.03 & 0.03 & 0.12 & 0.03 & 0.06 & 0.03 & 5.00 \\
\hline 06/03/2009 & 0.03 & 0.03 & 0.03 & 0.03 & 0.10 & 0.03 & 0.03 & 0.03 & 5.00 \\
\hline $06 / 17 / 2009$ & 0.030 & 0.03 & 0.03 & 0.03 & 1.57 & 0.03 & 0.03 & 0.03 & 5.00 \\
\hline 07/01/2009 & 0.03 & 0.03 & 0.03 & 0.03 & 1.72 & 0.03 & 0.03 & 0.03 & 5.00 \\
\hline 07/15/2009 & 0.03 & 0.03 & 0.03 & 0.03 & 0.23 & 0.03 & 0.06 & 0.03 & 5.00 \\
\hline 07/29/2009 & NS & NS & NS & NS & NS & NS & NS & NS & NS \\
\hline $08 / 12 / 2009$ & 0.03 & 0.03 & 0.03 & 0.03 & 0.03 & 0.03 & 0.03 & 0.03 & 6.68 \\
\hline $08 / 26 / 2009$ & NS & NS & NS & NS & NS & NS & NS & NS & NS \\
\hline 09/09/2009 & NS & NS & NS & NS & NS & NS & NS & NS & NS \\
\hline $10 / 07 / 2009$ & 0.03 & 0.03 & 0.03 & 0.12 & 0.10 & 0.03 & 0.03 & 0.03 & 5.00 \\
\hline $10 / 21 / 2009$ & 0.03 & 0.03 & 0.03 & 0.03 & 0.13 & 0.03 & 0.03 & 0.03 & 9.38 \\
\hline $11 / 04 / 2009$ & NS & NS & NS & NS & NS & NS & NS & NS & NS \\
\hline $11 / 18 / 2009$ & 0.03 & 0.03 & 0.03 & 0.03 & 0.03 & 0.03 & NS & 0.05 & 5.00 \\
\hline $12 / 02 / 2009$ & NS & NS & NS & NS & NS & NS & NS & NS & NS \\
\hline $12 / 16 / 2009$ & 0.32 & 0.03 & 0.03 & 0.04 & 0.06 & 0.32 & 0.04 & 0.41 & 5.00 \\
\hline $12 / 30 / 2009$ & 0.03 & 0.03 & 0.03 & 0.03 & 0.03 & 0.03 & 0.07 & 0.27 & 5.00 \\
\hline 01/13/2010 & NS & NS & NS & NS & NS & NS & NS & NS & NS \\
\hline 01/27/2010 & 0.11 & 0.03 & 0.03 & 0.03 & 0.04 & 0.03 & 0.22 & 0.34 & 5.00 \\
\hline 02/10/2009 & 0.26 & 0.03 & 0.03 & 0.03 & 0.07 & 0.03 & NS & 1.11 & 5.00 \\
\hline $02 / 24 / 2010$ & 0.05 & 0.03 & 0.03 & 0.03 & ND & 0.03 & NS & 0.96 & 5.00 \\
\hline 03/10/2010 & NS & NS & NS & NS & NS & NS & NS & NS & NS \\
\hline 03/24/2010 & 0.03 & 0.03 & 0.03 & 0.03 & 0.03 & 0.03 & 0.13 & 1.14 & 5.00 \\
\hline 04/07/2010 & 0.03 & 0.03 & 0.03 & 0.03 & 0.03 & 0.03 & 0.23 & 1.16 & 5.00 \\
\hline 06/17/2010 & 0.03 & 0.03 & 0.03 & 0.03 & 0.03 & 0.03 & 0.74 & 1.42 & 5.00 \\
\hline
\end{tabular}

$\mathrm{ND}=$ non-detect. The detection limit is $0.025 \mathrm{mg} / \mathrm{L}$ except for $\mathrm{P}$. *the detection limit for $\mathrm{P}$ is $5.0 \mathrm{mg} / \mathrm{L}$.

NS=no sample 


\section{TCLP Analysis}

Table A18. Pre TCLP leaching concentrations for bulk soil samples ( $n=3 ; p p m)$.

\begin{tabular}{|l|l|l|l|l|l|l|l|l|l|}
\hline \multirow{3}{*}{ Metal } & \multicolumn{3}{|c|}{ Control } & \multicolumn{3}{c|}{$7.62 \mathrm{~mm}$} & \multicolumn{3}{c|}{ Left 5\% TRAPPS } \\
\cline { 2 - 11 } & rep. 1 & rep. 2 & rep. 3 & rep. 1 & rep. 2 & rep. 3 & rep. 1 & rep. 2 & rep. 3 \\
\hline $\mathrm{Pb}$ & ND & ND & ND & ND & ND & ND & ND & ND & ND \\
\hline Cr & ND & ND & ND & ND & ND & ND & ND & ND & ND \\
\hline Cu & ND & ND & ND & ND & ND & ND & ND & ND & ND \\
\hline $\mathrm{Ni}$ & 0.03 & 0.03 & 0.03 & 0.07 & 0.07 & 0.08 & 0.06 & 0.07 & 0.08 \\
\hline Zn & ND & ND & ND & 0.14 & ND & 0.12 & 0.11 & 0.11 & 0.11 \\
\hline Fe & 0.07 & 1.10 & 0.09 & 0.16 & 0.61 & 0.42 & 0.88 & 0.81 & 0.31 \\
\hline $\mathrm{Mn}$ & ND & ND & ND & 0.46 & 0.50 & 0.47 & 0.33 & 0.37 & 0.41 \\
\hline Mo & ND & ND & ND & ND & ND & ND & ND & ND & ND \\
\hline V & ND & ND & ND & ND & ND & ND & ND & ND & ND \\
\hline Sb & ND & ND & ND & ND & ND & ND & ND & ND & ND \\
\hline Ca & 10.46 & 17.94 & 14.10 & 183.80 & 160.4 & 164.2 & 67.41 & 73.67 & 66.55 \\
\hline As & ND & ND & ND & ND & ND & ND & ND & ND & ND \\
\hline
\end{tabular}

$\mathrm{ND}=$ none detect; the detection limit is $0.025 \mathrm{ppm}$.

Table A19. Post TCLP leaching Pb, $\mathrm{Cr}, \mathrm{Cu}, \mathrm{Ni}, \mathrm{Zn}$, and Fe concentrations for bulk soil samples ( $\mathrm{n}=3 ; \mathrm{ppm}$ ).

\begin{tabular}{|l|l|l|l|l|l|l|l|l|l|l|l|l|l|}
\hline \multirow{2}{*}{ Metal } & \multicolumn{4}{|c|}{ Control } & \multicolumn{3}{c|}{ Left } & \multicolumn{3}{c|}{ 5\% TRAPPS ${ }^{\text {Inset lysimeter (5\% }}$} & \multicolumn{3}{c|}{ TTF) } \\
\cline { 2 - 14 } & rep. 1 & rep. 2 & rep. 3 & rep. 1 & rep. 2 & rep. 3 & rep. 1 & rep. 2 & rep. 3 & rep. 1 & rep. 2 & rep. 3 \\
\hline $\mathrm{Pb}$ & 483.00 & 470.30 & 466.80 & 151.00 & 145.30 & 145.90 & 63.85 & 64.60 & 64.13 & 2.59 & 1.32 & 1.16 \\
\hline $\mathrm{Cr}$ & ND & ND & ND & 0.05 & 0.05 & 0.05 & 0.05 & 0.05 & 0.05 & ND & ND & ND \\
\hline $\mathrm{Cu}$ & 28.23 & 28.00 & 28.10 & 4.56 & 4.71 & 4.59 & 6.56 & 6.54 & 6.56 & 0.21 & 0.19 & 0.19 \\
\hline $\mathrm{Ni}$ & 0.03 & 0.03 & 0.03 & 0.27 & 0.27 & 0.28 & 0.24 & 0.23 & 0.23 & 0.17 & 0.16 & 0.17 \\
\hline $\mathrm{Zn}$ & 3.02 & 2.98 & 2.95 & 1.18 & 1.19 & 1.20 & 1.24 & 1.23 & 1.21 & 0.09 & 0.09 & 0.09 \\
\hline $\mathrm{Fe}$ & 7.22 & 6.60 & 6.79 & 70.21 & 73.49 & 69.35 & 44.95 & 45.40 & 44.25 & 6.93 & 5.53 & 6.71 \\
\hline
\end{tabular}

$\mathrm{ND}=$ none detect; the detection limit is $0.025 \mathrm{ppm}$. 
Table A20. Post TCLP leaching Mn, Mo, V, Sb, Ca, and As concentrations for bulk soil samples ( $\mathrm{n}=3$; ppm).

\begin{tabular}{|l|l|l|l|l|l|l|l|l|l|l|l|l|}
\hline \multirow{2}{*}{ Metal } & \multicolumn{3}{|c|}{ Control } & \multicolumn{3}{c|}{$7.62 \mathrm{~mm}$} & \multicolumn{3}{c|}{ Left 5\% TRAPPS } & \multicolumn{3}{c|}{ Inset lysimeter (5\% TTF) } \\
\cline { 2 - 13 } & rep. 1 & rep. 2 & rep. 3 & rep. 1 & rep. 2 & rep. 3 & rep. 1 & rep. 2 & rep. 3 & rep. 1 & rep. 2 & rep. 3 \\
\hline Mn & 0.11 & 0.10 & 0.10 & 1.50 & 1.51 & 1.51 & 0.9 & 0.92 & 0.92 & 0.59 & 0.60 & 0.61 \\
\hline Mo & ND & ND & ND & ND & ND & ND & ND & ND & ND & ND & ND & ND \\
\hline V & ND & ND & ND & ND & ND & ND & ND & ND & ND & ND & ND & ND \\
\hline Ca & 5.22 & 5.38 & 5.35 & 0.43 & 0.43 & 0.42 & 0.07 & 0.08 & 0.04 & 0.03 & 0.03 & 0.03 \\
\hline As & 13.66 & 13.17 & 12.84 & 49.00 & 49.15 & 48.76 & 34.97 & 35.00 & 34.71 & 120.00 & 123.10 & 122.30 \\
\hline
\end{tabular}

$\mathrm{ND}=$ none detect; the detection limit is $0.025 \mathrm{ppm}$.

\section{DDI S\&S Leaching Analysis}

Table A21. Pre DDI leaching concentrations for bulk soil samples ( $n=3 ; p p m)$.

\begin{tabular}{|l|l|l|l|l|l|l|l|l|l|}
\hline \multirow{3}{*}{ Metal } & \multicolumn{3}{|c|}{ Control } & \multicolumn{3}{c|}{$7.62 \mathrm{~mm}$} & \multicolumn{3}{c|}{ Left 5\% TRAPPS } \\
\cline { 2 - 11 } & rep. 1 & rep. 2 & rep. 3 & rep. 1 & rep. 2 & rep. 3 & rep. 1 & rep. 2 & rep. 3 \\
\hline Pb & ND & ND & ND & ND & ND & ND & ND & ND & ND \\
\hline Cr & ND & ND & ND & ND & ND & ND & ND & ND & ND \\
\hline Cu & ND & ND & ND & ND & ND & ND & ND & ND & ND \\
\hline Ni & ND & ND & ND & ND & ND & ND & ND & ND & ND \\
\hline Zn & ND & ND & ND & ND & ND & ND & ND & ND & ND \\
\hline Fe & N.43 & N.36 & 0.40 & 2.25 & 1.62 & 1.97 & 2.29 & 1.97 & 2.14 \\
\hline $\mathrm{Mn}$ & ND & ND & ND & ND & ND & ND & ND & ND & ND \\
\hline Mo & ND & ND & ND & ND & ND & ND & ND & ND & ND \\
\hline V & ND & ND & ND & ND & ND & ND & ND & ND & ND \\
\hline Sb & ND & ND & ND & ND & ND & ND & ND & ND & ND \\
\hline Ca & 7.24 & 6.44 & 8.18 & 18.60 & 16.97 & 18.60 & 12.19 & 11.67 & 14.46 \\
\hline As & ND & ND & ND & ND & ND & ND & ND & ND & ND \\
\hline
\end{tabular}

$\mathrm{ND}=$ none detect; the detection limit is $0.025 \mathrm{ppm}$. 
Table A22. Post DDI Suspend and Settle Pb, $\mathrm{Cr}, \mathrm{Cu}, \mathrm{Ni}, \mathrm{Zn}$, and Fe concentrations for bulk soil samples ( $\mathrm{n=3}$; ppm).

\begin{tabular}{|c|c|c|c|c|c|c|c|c|c|c|c|c|}
\hline \multirow[b]{2}{*}{ Metal } & \multicolumn{3}{|c|}{ Control } & \multicolumn{3}{|c|}{$7.62 \mathrm{~mm}$} & \multicolumn{3}{|c|}{ Left 5\% TRAPPS ${ }^{\mathrm{TM}}$} & \multicolumn{3}{|c|}{ Inset lysimeter ( $5 \%$ TTF) } \\
\hline & rep. 1 & rep. 2 & rep. 3 & rep. 1 & rep. 2 & rep. 3 & rep. 1 & rep. 2 & rep. 3 & rep. 1 & rep. 2 & rep. 3 \\
\hline $\mathrm{Pb}$ & 0.37 & 0.36 & 0.39 & 0.44 & 0.44 & 0.43 & 0.05 & 0.42 & 0.04 & 0.32 & 0.35 & 0.43 \\
\hline $\mathrm{Cr}$ & ND & ND & ND & ND & ND & ND & ND & ND & ND & ND & ND & ND \\
\hline $\mathrm{Cu}$ & 0.54 & 0.57 & 0.58 & 0.06 & 0.06 & 0.06 & ND & ND & ND & 0.54 & 0.57 & 0.58 \\
\hline $\mathrm{Ni}$ & ND & ND & ND & ND & ND & ND & ND & ND & ND & ND & ND & ND \\
\hline $\mathrm{Zn}$ & 0.10 & 0.09 & 0.93 & ND & ND & ND & ND & ND & ND & 0.10 & 0.09 & 0.09 \\
\hline $\mathrm{Fe}$ & ND & ND & ND & 0.35 & 0.35 & 0.35 & ND & ND & ND & ND & ND & ND \\
\hline
\end{tabular}

$\mathrm{ND}=$ none detect; the detection limit is $0.025 \mathrm{ppm}$.

Table A23. Post DDI Suspend and Settle leaching Mn, Mo, V, Sb, Ca, and As concentrations for bulk soil samples $(n=3 ; p p m)$.

\begin{tabular}{|l|l|l|l|l|l|l|l|l|l|l|l|l|l|}
\hline \multirow{3}{*}{ Metal } & \multicolumn{3}{l}{ Control } & \multicolumn{3}{l}{ 7.62 mm } & \multicolumn{2}{l|}{ Left 5\% TRAPPS } & \multicolumn{2}{l|}{ Inset lysimeter (5\% TTF) } \\
\cline { 2 - 14 } & rep. 1 & rep. 2 & rep. 3 & rep. 1 & rep. 2 & rep. 3 & rep. 1 & rep. 2 & rep. 3 & rep. 1 & rep. 2 & rep. 3 \\
\hline Mn & ND & ND & ND & ND & ND & ND & ND & ND & ND & ND & ND & ND \\
\hline Mo & ND & ND & ND & ND & ND & ND & ND & ND & ND & ND & ND & ND \\
\hline V & ND & ND & ND & ND & ND & ND & ND & ND & ND & ND & ND & ND \\
\hline Sb & 0.21 & 0.21 & 0.20 & 0.17 & 0.17 & 0.17 & 0.29 & 0.29 & 0.28 & 0.21 & 0.21 & 0.20 \\
\hline Ca & 11.91 & 12.01 & 11.90 & 3.72 & 3.63 & 3.76 & 5.95 & 6.07 & 6.06 & 11.91 & 12.01 & 11.89 \\
\hline As & ND & ND & ND & ND & ND & ND & ND & ND & ND & ND & ND & ND \\
\hline
\end{tabular}

$\mathrm{ND}=$ none detect; the detection limit is $0.025 \mathrm{ppm}$.

\section{SPLP Leaching Analysis}

Table A24. Pre SPLP leaching concentrations for bulk soil samples ( $n=3 ; p p m)$.

\begin{tabular}{|l|l|l|l|l|l|l|l|l|l|}
\hline \multirow{3}{*}{ Metal } & \multicolumn{3}{|c|}{ Control } & \multicolumn{3}{c|}{ 7.62 mm } & \multicolumn{3}{c|}{ Left 5\% TRAPPTM } \\
\cline { 2 - 11 } & rep. 1 & rep. 2 & rep. 3 & rep. 1 & rep. 2 & rep. 3 & rep. 1 & rep. 2 & rep. 3 \\
\hline $\mathrm{Pb}$ & ND & ND & ND & ND & ND & ND & ND & ND & ND \\
\hline Cr & ND & ND & ND & ND & ND & ND & ND & ND & ND \\
\hline $\mathrm{Ni}$ & ND & ND & ND & ND & ND & ND & ND & ND & ND \\
\hline Zn & ND & ND & ND & ND & ND & ND & ND & ND & ND \\
\hline Fe & O.23 & O.17 & ND & ND & ND & ND & ND & ND & ND \\
\hline Mn & ND & ND & ND & ND & ND & ND & 0.29 & 0.24 & 0.18 \\
\hline Mo & ND & ND & ND & ND & ND & ND & ND & ND & ND \\
\hline
\end{tabular}




\begin{tabular}{|l|l|l|l|l|l|l|l|l|l|}
\hline \multirow{3}{*}{ Metal } & \multicolumn{3}{|c|}{ Control } & \multicolumn{3}{c|}{$7.62 \mathrm{~mm}$} & \multicolumn{3}{c|}{ Left 5\% TRAPPS } \\
\cline { 2 - 11 } & rep. 1 & rep. 2 & rep. 3 & rep. 1 & rep. 2 & rep. 3 & rep. 1 & rep. 2 & rep. 3 \\
\hline V & ND & ND & ND & ND & ND & ND & ND & ND & ND \\
\hline Sb & ND & ND & ND & ND & ND & ND & ND & ND & ND \\
\hline Ca & 4.88 & 4.63 & 4.67 & 17.97 & 17.15 & 17.38 & 16.52 & 7.64 & 6.46 \\
\hline As & ND & ND & ND & ND & ND & ND & ND & ND & ND \\
\hline
\end{tabular}

$\mathrm{ND}=$ none detect; the detection limit is $0.025 \mathrm{ppm}$.

Table A25. Post SPLP Pb, $\mathrm{Cr}, \mathrm{Cu}, \mathrm{Ni}, \mathrm{Zn}$, and Fe concentrations for bulk soil samples $(\mathrm{n}=3$; ppm).

\begin{tabular}{|c|c|c|c|c|c|c|c|c|c|c|c|c|}
\hline \multirow[b]{2}{*}{ Metal } & \multicolumn{3}{|c|}{ Control } & \multicolumn{3}{|c|}{$7.62 \mathrm{~mm}$} & \multicolumn{3}{|c|}{ Left 5\% TRAPPS ${ }^{\mathrm{TM}}$} & \multicolumn{3}{|c|}{ Inset lysimeter ( $5 \%$ TTF) } \\
\hline & rep. 1 & rep. 2 & rep. 3 & rep. 1 & rep. 2 & rep. 3 & rep. 1 & rep. 2 & rep. 3 & rep. 1 & rep. 2 & rep. 3 \\
\hline $\mathrm{Pb}$ & 1.63 & 5.43 & 0.33 & 0.54 & 0.12 & 0.94 & 0.13 & 0.12 & 0.14 & 0.16 & 0.11 & 0.08 \\
\hline $\mathrm{Cr}$ & ND & ND & ND & ND & ND & ND & ND & ND & ND & ND & ND & ND \\
\hline $\mathrm{Cu}$ & 0.51 & 1.25 & 0.08 & 0.14 & 0.04 & 0.21 & 0.09 & 0.08 & 0.09 & 0.04 & 0.04 & ND \\
\hline $\mathrm{Ni}$ & ND & ND & ND & ND & ND & ND & ND & ND & ND & ND & ND & ND \\
\hline $\mathrm{Zn}$ & 0.17 & 0.24 & ND & ND & ND & ND & 0.06 & 0.05 & 0.05 & ND & ND & ND \\
\hline $\mathrm{Fe}$ & 0.13 & ND & ND & 0.50 & 0.08 & 0.63 & 0.09 & 0.07 & 0.07 & 0.17 & 0.20 & 0.16 \\
\hline
\end{tabular}

$\mathrm{ND}=$ none detect; the detection limit is $0.025 \mathrm{ppm}$.

Table A26. Post SPLP Mn, Mo, V, Sb, Ca, and As concentrations for bulk soil samples ( $n=3$; ppm).

\begin{tabular}{|l|l|l|l|l|l|l|l|l|l|l|l|l|}
\hline \multirow{3}{*}{ Metal } & \multicolumn{3}{|c|}{ Control } & \multicolumn{3}{c|}{$7.62 \mathrm{~mm}$} & \multicolumn{3}{c|}{ Left 5\% TRAPPSTM } & \multicolumn{3}{c|}{ Inset lysimeter (5\% TTF) } \\
\cline { 2 - 13 } & rep. 1 & rep. 2 & rep. 3 & rep. 1 & rep. 2 & rep. 3 & rep. 1 & rep. 2 & rep. 3 & rep. 1 & rep. 2 & rep. 3 \\
\hline Mn & ND & ND & ND & ND & ND & ND & ND & ND & ND & ND & ND & ND \\
\hline Mo & ND & ND & ND & ND & ND & ND & ND & ND & ND & ND & ND & ND \\
\hline V & ND & ND & ND & ND & ND & ND & ND & ND & ND & ND & ND & ND \\
\hline Sb & 0.23 & 0.26 & 0.15 & 0.13 & 0.13 & 0.11 & 0.38 & 0.37 & 0.38 & ND & ND & ND \\
\hline Ca & 3.77 & 2.68 & 1.68 & 3.53 & 3.21 & 7.23 & 22.29 & 21.19 & 21.70 & 8.63 & 9.33 & 8.09 \\
\hline As & ND & ND & ND & ND & ND & ND & ND & ND & ND & ND & ND & ND \\
\hline
\end{tabular}

$\mathrm{ND}=$ none detect; the detection limit is $0.025 \mathrm{ppm}$. 


\section{Soil Samples - Metal Concentrations}

Table A27. Digested post soil concentrations $\mathrm{Pb}, \mathrm{Cr}, \mathrm{Cu}, \mathrm{Ni}, \mathrm{Zn}$, and $\mathrm{Fe}(\mathrm{n}=3 ; \mathrm{ppm})$.

\begin{tabular}{|l|l|l|l|l|l|l|l|l|l|l|l|l|}
\hline \multirow{2}{*}{ Metal } & \multicolumn{3}{l|}{ Control } & \multicolumn{2}{l}{ 7.62 mm } & \multicolumn{2}{l|}{ Left 5\% TRAPPS } & \multicolumn{3}{l|}{ Inset lysimeter (5\% TTF) } \\
\cline { 2 - 13 } & rep. 1 & rep. 2 & rep. 3 & rep. 1 & rep. 2 & rep. 3 & rep. 1 & rep. 2 & rep. 3 & rep. 1 & rep. 2 & rep. 3 \\
\hline $\mathrm{Pb}$ & 9227 & 9077 & 12340 & 1862 & 3502 & 2068 & 6147 & 7180 & 6367 & 186 & 171 & 201.8 \\
\hline $\mathrm{Cr}$ & $\mathrm{ND}$ & ND & ND & 12.48 & 12.68 & 13.35 & ND & ND & ND & 30.08 & 22.34 & 19.69 \\
\hline $\mathrm{Cu}$ & 1190 & 790.6 & 733.7 & 355.6 & 340.7 & 364.3 & 614.40 & 639.00 & 630.30 & 99.05 & 71.49 & 115.7 \\
\hline $\mathrm{Ni}$ & ND & ND & ND & 7.764 & 8.566 & 8.662 & ND & ND & ND & 20.77 & 14.48 & 12.29 \\
\hline $\mathrm{Zn}$ & 119.8 & 80.55 & 76.98 & 34.84 & 36.43 & 40.36 & 60.72 & 63.40 & 62.06 & 14.99 & 10.57 & 14.00 \\
\hline $\mathrm{Fe}$ & 646.5 & 598.5 & 723.8 & 6386 & 7152 & 6689 & 2485 & 1524 & 2224 & 20730 & 11400 & 14480 \\
\hline
\end{tabular}

$\mathrm{ND}=$ none detect; the detection limit is $0.025 \mathrm{ppm}$.

Table A28. Digested post soil concentrations for Mn, Mo, V, Sb, Ca, As, and P ( $n=3 ; \mathrm{ppm}$ ).

\begin{tabular}{|l|l|l|l|l|l|l|l|l|l|l|l|l|l|}
\hline \multirow{2}{*}{ Metal } & \multicolumn{3}{|c|}{ Control } & \multicolumn{3}{c}{$7.62 \mathrm{~mm}$} & \multicolumn{3}{c|}{ Left 5\% TRAPPSTM } & \multicolumn{3}{c|}{ Inset lysimeter } \\
(5\% TTF) \\
\cline { 2 - 15 } & rep. 1 & rep. 2 & rep. 3 & rep. 1 & rep. 2 & rep. 3 & rep. 1 & rep. 2 & rep. 3 & rep. 1 & rep. 2 & rep. 3 \\
\hline Mn & ND & ND & ND & 38.29 & 39.62 & 39.89 & 11.81 & 8.172 & 11.10 & 120.4 & 67.79 & 72.38 \\
\hline Mo & ND & ND & ND & 5.061 & ND & 6.526 & ND & ND & ND & 10.84 & 10.67 & 7.215 \\
\hline V & ND & ND & ND & ND & ND & ND & ND & ND & ND & 12.74 & 6.508 & 7.385 \\
\hline Sb & 107.9 & 104.2 & 133 & 19.2 & 45.8 & 20.31 & 62.17 & 92.57 & 68.03 & ND & ND & ND \\
\hline Ca & 358.1 & 355.6 & 402.6 & 3700 & 3716 & 3866 & 1092 & 1105 & 1097 & 4514 & 4107 & 4199 \\
\hline As & 5.643 & 6.293 & 8.809 & ND & ND & ND & ND & ND & ND & ND & ND & ND \\
\hline P & ND & ND & ND & 2815 & 3096 & 2914 & 2207 & 2063 & 2024 & 3977 & 3570 & 3639 \\
\hline
\end{tabular}

$\mathrm{ND}=$ none detect; the detection limit is $0.025 \mathrm{ppm}$.

Table A29. Post soil digests concentrations for control lysimeter at 0-4L:0-5H.

\begin{tabular}{|l|l|l|l|l|l|l|l|}
\hline Sample & $\mathrm{Pb}$ & $\mathrm{Cr}$ & $\mathrm{Cu}$ & $\mathrm{Ni}$ & $\mathrm{Zn}$ & $\mathrm{Fe}$ & $\mathrm{Mn}$ \\
\hline 1 & 1386.00 & $\mathrm{ND}$ & 102.17 & $\mathrm{ND}$ & 14.05 & 231.90 & $\mathrm{ND}$ \\
\hline 2 & 554.60 & $\mathrm{ND}$ & 46.32 & $\mathrm{ND}$ & 7.59 & 170.27 & $\mathrm{ND}$ \\
\hline 3 & 1441.33 & $\mathrm{ND}$ & 86.18 & $\mathrm{ND}$ & 12.73 & 126.90 & $\mathrm{ND}$ \\
\hline 4 & 1275.00 & $\mathrm{ND}$ & 85.82 & $\mathrm{ND}$ & 10.56 & 127.40 & $\mathrm{ND}$ \\
\hline 5 & 1266.00 & $\mathrm{ND}$ & 147.10 & $\mathrm{ND}$ & 14.92 & 135.03 & $\mathrm{ND}$ \\
\hline 6 & 1506.00 & $\mathrm{ND}$ & 122.37 & $\mathrm{ND}$ & 14.32 & 169.50 & $\mathrm{ND}$ \\
\hline 7 & 5236.33 & $\mathrm{ND}$ & 614.30 & $\mathrm{ND}$ & 62.16 & 418.83 & $\mathrm{ND}$ \\
\hline 8 & 5124.00 & $\mathrm{ND}$ & 468.00 & $\mathrm{ND}$ & 47.95 & 342.50 & $\mathrm{ND}$ \\
\hline 9 & 4611.00 & $\mathrm{ND}$ & 362.73 & $\mathrm{ND}$ & 37.63 & 618.20 & $\mathrm{ND}$ \\
\hline
\end{tabular}

$\mathrm{ND}=$ none detect; the detection limit is $5 \mathrm{ppm}$ for all metals except for $\mathrm{P}$. The detection limit for $\mathrm{P}$ is $5 \mathrm{ppm}$. 


\begin{tabular}{|l|l|l|l|l|l|l|}
\hline Sample & Mo & V & Sb & Ca & As & P \\
\hline 1 & ND & ND & 18.78 & 180.97 & ND & 87.53 \\
\hline 2 & ND & ND & 7.52 & 303.50 & ND & 124.53 \\
\hline 3 & ND & ND & 13.47 & 233.53 & ND & 106.57 \\
\hline 4 & ND & ND & 10.39 & 234.53 & ND & 70.69 \\
\hline 5 & ND & ND & 16.19 & 201.10 & ND & 107.55 \\
\hline 6 & ND & ND & 13.65 & 102.57 & ND & 79.50 \\
\hline 7 & ND & ND & 49.78 & 281.87 & ND & 71.02 \\
\hline 8 & ND & ND & 55.09 & 236.13 & ND & 112.90 \\
\hline 9 & ND & ND & 43.65 & 718.73 & ND & 124.43 \\
\hline
\end{tabular}

$\mathrm{ND}=$ none detect; the detection limit is $5 \mathrm{ppm}$ for all metals except for $\mathrm{P}$. The detection limit for $\mathrm{P}$ is $5 \mathrm{ppm}$.

Table A30. Post soil digests concentrations for control lysimeter at 0-4L:5-10H.

\begin{tabular}{|l|l|l|l|l|l|l|l|}
\hline Sample & $\mathrm{Pb}$ & $\mathrm{Cr}$ & $\mathrm{Cu}$ & $\mathrm{Ni}$ & $\mathrm{Zn}$ & $\mathrm{Fe}$ & $\mathrm{Mn}$ \\
\hline 1 & 1696.30 & $\mathrm{ND}$ & 239.77 & $\mathrm{ND}$ & 25.54 & 450.47 & $\mathrm{ND}$ \\
\hline 2 & 13043 & $\mathrm{ND}$ & 1131.50 & $\mathrm{ND}$ & 116.27 & 713.3 & $\mathrm{ND}$ \\
\hline 3 & 4933.70 & $\mathrm{ND}$ & 467.27 & $\mathrm{ND}$ & 48.97 & 520.6 & $\mathrm{ND}$ \\
\hline 4 & 6850.30 & $\mathrm{ND}$ & 410.93 & $\mathrm{ND}$ & 42.30 & 394.47 & $\mathrm{ND}$ \\
\hline 5 & 7553.30 & $\mathrm{ND}$ & 590.93 & $\mathrm{ND}$ & 62.39 & 416.2 & $\mathrm{ND}$ \\
\hline 6 & 7162.70 & $\mathrm{ND}$ & 626.65 & $\mathrm{ND}$ & 67.31 & 423.43 & $\mathrm{ND}$ \\
\hline 7 & 5797.30 & $\mathrm{ND}$ & 568.05 & $\mathrm{ND}$ & 61.46 & 336 & $\mathrm{ND}$ \\
\hline 8 & 6023.70 & $\mathrm{ND}$ & 718.75 & $\mathrm{ND}$ & 71.517 & 408.2 & $\mathrm{ND}$ \\
\hline 9 & 6199.30 & $\mathrm{ND}$ & 614.75 & $\mathrm{ND}$ & 64.89 & 417.1 & $\mathrm{ND}$ \\
\hline
\end{tabular}

$\mathrm{ND}=$ none detect; the detection limit is $5 \mathrm{ppm}$ for all metals except for $\mathrm{P}$. The detection limit for $\mathrm{P}$ is $5 \mathrm{ppm}$.

\begin{tabular}{|l|l|l|l|l|l|l|}
\hline Sample & Mo & V & Sb & Ca & As & P \\
\hline 1 & ND & ND & 14.29 & 257.67 & ND & 109.19 \\
\hline 2 & ND & ND & 156.53 & 366 & 9.36 & 146.40 \\
\hline 3 & ND & ND & 68.48 & 451.57 & ND & 128.43 \\
\hline 4 & ND & ND & 66.65 & 411.33 & ND & 92.36 \\
\hline 5 & ND & ND & 159.50 & 329.30 & 5.53 & 129.41 \\
\hline 6 & ND & ND & 199.23 & 404.27 & ND & 101.34 \\
\hline 7 & ND & ND & 185.63 & 719.80 & ND & 92.89 \\
\hline 8 & ND & ND & 102.50 & 348.20 & 5.78 & 134.73 \\
\hline 9 & ND & ND & 215.25 & 390.40 & ND & 132.97 \\
\hline
\end{tabular}

$\mathrm{ND}=$ none detect; the detection limit is $5 \mathrm{ppm}$ for all metals except for $\mathrm{P}$. The detection limit for $\mathrm{P}$ is $5 \mathrm{ppm}$. 
Table A31. Post soil digests concentrations for control lysimeter at 4-8L:0-5H (ppm).

\begin{tabular}{|l|l|l|l|l|l|l|l|}
\hline Sample & $\mathrm{Pb}$ & $\mathrm{Cr}$ & $\mathrm{Cu}$ & $\mathrm{Ni}$ & $\mathrm{Zn}$ & $\mathrm{Fe}$ & $\mathrm{Mn}$ \\
\hline 1 & 5779.00 & $\mathrm{ND}$ & 535.50 & $\mathrm{ND}$ & 54.51 & 608.83 & ND \\
\hline 2 & 4205.50 & $\mathrm{ND}$ & 385.90 & $\mathrm{ND}$ & 42.94 & 440.00 & ND \\
\hline 3 & 2727.00 & $\mathrm{ND}$ & 247.40 & $\mathrm{ND}$ & 27.79 & 304.20 & ND \\
\hline 4 & 5261.30 & $\mathrm{ND}$ & 320.87 & $\mathrm{ND}$ & 35.55 & 316.30 & ND \\
\hline 5 & 4367.30 & $\mathrm{ND}$ & 360.55 & $\mathrm{ND}$ & 39.375 & 180.20 & ND \\
\hline 6 & 753.13 & $\mathrm{ND}$ & 42.16 & $\mathrm{ND}$ & 6.52 & 121.03 & ND \\
\hline 7 & 7904.00 & $\mathrm{ND}$ & 837.10 & $\mathrm{ND}$ & 86.76 & 766.43 & ND \\
\hline 8 & 5996.50 & $\mathrm{ND}$ & 922.30 & $\mathrm{ND}$ & 100.62 & 567.00 & ND \\
\hline 9 & 142.50 & $\mathrm{ND}$ & 12.69 & $\mathrm{ND}$ & $\mathrm{ND}$ & 131.53 & ND \\
\hline
\end{tabular}

$\mathrm{ND}=$ none detect; the detection limit is $5 \mathrm{ppm}$ for all metals except for $\mathrm{P}$. The detection limit for $\mathrm{P}$ is $5 \mathrm{ppm}$.

\begin{tabular}{|l|l|l|l|l|l|l|}
\hline Sample & Mo & V & Sb & Ca & As & P \\
\hline 1 & ND & ND & 85.29 & 348.33 & 5.77 & 96.86 \\
\hline 2 & ND & ND & 67.98 & 307.00 & ND & 133.90 \\
\hline 3 & ND & ND & 28.62 & 341.07 & ND & 115.90 \\
\hline 4 & ND & ND & 60.21 & 251.20 & ND & 79.80 \\
\hline 5 & ND & ND & 52.12 & 189.33 & ND & 116.90 \\
\hline 6 & ND & ND & 7.44 & 157.27 & ND & 88.89 \\
\hline 7 & ND & ND & 121.67 & 365 & 5.58 & 80.41 \\
\hline 8 & ND & ND & 66.56 & 478.87 & 5.17 & 122.23 \\
\hline 9 & ND & ND & ND & 355.47 & ND & 133.83 \\
\hline
\end{tabular}

$\mathrm{ND}=$ none detect; the detection limit is $5 \mathrm{ppm}$ for all metals except for $\mathrm{P}$. The detection limit for $\mathrm{P}$ is $5 \mathrm{ppm}$.

Table A32. Post soil digests concentrations for control lysimeter at 4-8L:5-10H (ppm).

\begin{tabular}{|l|l|l|l|l|l|l|l|}
\hline Sample & $\mathrm{Pb}$ & $\mathrm{Cr}$ & $\mathrm{Cu}$ & $\mathrm{Ni}$ & $\mathrm{Zn}$ & $\mathrm{Fe}$ & $\mathrm{Mn}$ \\
\hline 1 & 16043 & $\mathrm{ND}$ & 1144 & $\mathrm{ND}$ & 121.13 & 723.9 & $\mathrm{ND}$ \\
\hline 2 & 6120 & $\mathrm{ND}$ & 625.73 & $\mathrm{ND}$ & 66.823 & 352.97 & $\mathrm{ND}$ \\
\hline 3 & 4728 & $\mathrm{ND}$ & 458.03 & $\mathrm{ND}$ & 46.907 & 342.4 & $\mathrm{ND}$ \\
\hline 4 & 17400 & $\mathrm{ND}$ & 1302.3 & $\mathrm{ND}$ & 134.7 & 713.8 & $\mathrm{ND}$ \\
\hline 5 & 10995 & $\mathrm{ND}$ & 682.05 & $\mathrm{ND}$ & 71.425 & 541.83 & $\mathrm{ND}$ \\
\hline 6 & 7083.3 & $\mathrm{ND}$ & 469.07 & $\mathrm{ND}$ & 53.823 & 252.1 & $\mathrm{ND}$ \\
\hline 7 & 7287.3 & $\mathrm{ND}$ & 776.23 & $\mathrm{ND}$ & 80.837 & 718.1 & ND \\
\hline 8 & 6392 & $\mathrm{ND}$ & 723.97 & $\mathrm{ND}$ & 74.71 & 510.07 & ND \\
\hline 9 & 2094.3 & $\mathrm{ND}$ & 217.37 & $\mathrm{ND}$ & 23.037 & 288.43 & ND \\
\hline
\end{tabular}

$\mathrm{ND}=$ none detect; the detection limit is $5 \mathrm{ppm}$ for all metals except for $\mathrm{P}$. The detection limit for $\mathrm{P}$ is $5 \mathrm{ppm}$. 


\begin{tabular}{|l|l|l|l|l|l|l|}
\hline Sample & Mo & V & Sb & Ca & As & P \\
\hline 1 & ND & ND & 425.80 & 591.17 & 12.44 & 110.80 \\
\hline 2 & ND & ND & 59.06 & 383.80 & 6.51 & 147.90 \\
\hline 3 & ND & ND & 41.89 & 450.13 & ND & 130.10 \\
\hline 4 & ND & ND & 246.33 & 388.33 & 13.39 & 94.00 \\
\hline 5 & ND & ND & 368.43 & 305.93 & 6.08 & 130.90 \\
\hline 6 & ND & ND & 78.91 & 573.70 & ND & 102.84 \\
\hline 7 & ND & ND & 83.53 & 414.30 & 5.37 & 94.39 \\
\hline 8 & ND & ND & 76.83 & 525.47 & 5.18 & 136.23 \\
\hline 9 & ND & ND & 29.82 & 492.23 & ND & 127.63 \\
\hline
\end{tabular}

$\mathrm{ND}=$ none detect; the detection limit is $5 \mathrm{ppm}$ for all metals except for $\mathrm{P}$. The detection limit for $\mathrm{P}$ is $5 \mathrm{ppm}$.

Table A33. Post soil digests concentrations for $7.62 \mathrm{~mm}$ lysimeter at 0-4L:0-5H (ppm).

\begin{tabular}{|l|l|l|l|l|l|l|l|}
\hline Sample & $\mathrm{Pb}$ & $\mathrm{Cr}$ & $\mathrm{Cu}$ & $\mathrm{Ni}$ & $\mathrm{Zn}$ & $\mathrm{Fe}$ & $\mathrm{Mn}$ \\
\hline 1 & 1320.33 & 11.67 & 235.63 & 6.69 & 25.30 & 5376.67 & 33.32 \\
\hline 2 & 1525.00 & 12.23 & 306.73 & 6.95 & 29.88 & 5857.33 & 33.51 \\
\hline 3 & 3714.33 & 15.81 & 433.40 & 7.83 & 38.67 & 6361.67 & 38.16 \\
\hline 4 & 1486.67 & 16.62 & 167.03 & 9.84 & 20.38 & 6852.00 & 44.14 \\
\hline 5 & 1082.53 & 11.09 & 141.20 & 7.50 & 15.49 & 4465.33 & 36.63 \\
\hline 6 & 71.77 & 15.78 & 70.43 & 8.46 & 8.82 & 5620.00 & 39.76 \\
\hline 7 & 276.07 & 15.82 & 69.25 & 8.33 & 10.12 & 7615.67 & 36.20 \\
\hline 8 & 876.17 & 8.97 & 125.35 & 5.85 & 12.66 & 4378.33 & 29.68 \\
\hline 9 & 167.33 & 16.99 & 65.57 & 9.57 & 9.63 & 6843.33 & 42.95 \\
\hline
\end{tabular}

$\mathrm{ND}=$ none detect; the detection limit is $5 \mathrm{ppm}$ for all metals except for $\mathrm{P}$. The detection limit for $\mathrm{P}$ is $5 \mathrm{ppm}$.

\begin{tabular}{|l|l|l|l|l|l|l|}
\hline Sample & Mo & V & Sb & Ca & As & P \\
\hline 1 & 6.07 & ND & 11.01 & 5487.00 & ND & 1559.00 \\
\hline 2 & 5.21 & ND & 17.00 & 3560.33 & ND & 1597.38 \\
\hline 3 & 6.09 & ND & 41.80 & 3026.67 & ND & 1367.77 \\
\hline 4 & 7.26 & ND & 16.71 & 5710.67 & ND & 1683.12 \\
\hline 5 & ND & ND & 14.96 & 12411.33 & ND & 2171.97 \\
\hline 6 & ND & ND & ND & 4196.67 & ND & 2385.04 \\
\hline 7 & ND & ND & ND & 3580.33 & ND & 2434.27 \\
\hline 8 & ND & 5.45 & ND & 8295.00 & ND & 1442.02 \\
\hline 9 & ND & 6.28 & ND & 5840.00 & ND & 1756.10 \\
\hline
\end{tabular}

$\mathrm{ND}=$ none detect; the detection limit is $5 \mathrm{ppm}$ for all metals except for $\mathrm{P}$. The detection limit for $\mathrm{P}$ is $5 \mathrm{ppm}$. 
Table A34. Post soil digests concentrations for $7.62 \mathrm{~mm}$ lysimeter at 0-4L:5-10H (ppm).

\begin{tabular}{|l|l|l|l|l|l|l|l|}
\hline Sample & $\mathrm{Pb}$ & $\mathrm{Cr}$ & $\mathrm{Cu}$ & $\mathrm{Ni}$ & $\mathrm{Zn}$ & $\mathrm{Fe}$ & $\mathrm{Mn}$ \\
\hline 1 & 7989.67 & 20.90 & 597.90 & 13.11 & 57.53 & 10304 & 57.59 \\
\hline 2 & 2520.00 & 23.58 & 315.50 & 17.02 & 27.16 & 12020 & 87.15 \\
\hline 3 & 9483.67 & 17.10 & 644.27 & 12.77 & 73.44 & 9436 & 44.16 \\
\hline 4 & 7352.50 & 21.33 & 526.50 & $\mathrm{ND}$ & 70.04 & 11440 & 50.34 \\
\hline 5 & 12315.00 & 18.61 & 1232.33 & ND & 129.77 & 11430 & 47.89 \\
\hline 6 & 2360.33 & 16.97 & 312.43 & ND & 18.98 & 8062 & 47.13 \\
\hline 7 & 5877.33 & 17.76 & 687.30 & 6.42 & 101.80 & 6598.67 & 34.92 \\
\hline 8 & 7213.33 & 20.01 & 647.55 & 15.55 & 79.51 & 6639.00 & 35.08 \\
\hline 9 & NS & NS & NS & NS & NS & NS & NS \\
\hline
\end{tabular}

$\mathrm{ND}=$ none detect; the detection limit is $5 \mathrm{ppm}$ for all metals except for $\mathrm{P}$. The detection limit for $\mathrm{P}$ is $5 \mathrm{ppm}$.

\begin{tabular}{|l|l|l|l|l|l|l|}
\hline Sample & Mo & V & Sb & Ca & As & P \\
\hline 1 & ND & 7.94 & 61.66 & 1506.33 & ND & 3186.07 \\
\hline 2 & ND & 9.42 & ND & 2522.67 & ND & 1310.47 \\
\hline 3 & ND & 10.65 & 62.53 & 3432.67 & 16.94 & 2214.37 \\
\hline 4 & ND & 10.65 & 58.83 & 3842.33 & ND & 2448.16 \\
\hline 5 & ND & 10.65 & 56.25 & 3175 & 37.11 & 3128.41 \\
\hline 6 & ND & 8.67 & ND & 1865.67 & 15.60 & 2421.01 \\
\hline 7 & 17.80 & 10.37 & 102.43 & 2156.33 & ND & 1889.29 \\
\hline 8 & 18.42 & ND & 114.54 & 4580.67 & ND & 2632.13 \\
\hline 9 & NS & NS & NS & NS & NS & NS \\
\hline
\end{tabular}

$\mathrm{ND}=$ none detect; the detection limit is $5 \mathrm{ppm}$ for all metals except for $\mathrm{P}$. The detection limit for $\mathrm{P}$ is $5 \mathrm{ppm}$.

Table A35. Post soil digests concentrations for $7.62 \mathrm{~mm}$ lysimeter at 4-8L:0-5H (ppm).

\begin{tabular}{|l|l|l|l|l|l|l|l|}
\hline Sample & $\mathrm{Pb}$ & $\mathrm{Cr}$ & $\mathrm{Cu}$ & $\mathrm{Ni}$ & $\mathrm{Zn}$ & $\mathrm{Fe}$ & $\mathrm{Mn}$ \\
\hline 1 & 7128.00 & 12.05 & 632.45 & 14.12 & 67.15 & 6556.67 & 37.53 \\
\hline 2 & 1847.50 & 13.52 & 223.33 & 11.47 & 31.76 & 5414.00 & 32.88 \\
\hline 3 & 206.53 & 17.34 & 76.69 & 7.43 & 14.60 & 6435.00 & 40.04 \\
\hline 4 & 1507.50 & 19.64 & 117.17 & 10.86 & 13.84 & 8384.00 & 44.02 \\
\hline 5 & 206.83 & 15.03 & 56.42 & 8.50 & 12.04 & 6867.50 & 36.62 \\
\hline 6 & 167.70 & 17.21 & 69.71 & 10.41 & 10.41 & 7690.33 & 34.14 \\
\hline 7 & 6631.50 & 15.36 & 278.30 & 9.25 & 32.12 & 7701.50 & 32.60 \\
\hline 8 & 1773.50 & 15.43 & 197.00 & 10.09 & 26.59 & 7146.33 & 34.33 \\
\hline 9 & 3471.00 & 14.77 & 131.50 & 8.43 & 24.42 & 7211.00 & 33.90 \\
\hline
\end{tabular}

$\mathrm{ND}=$ none detect; the detection limit is $5 \mathrm{ppm}$ for all metals except for $\mathrm{P}$. The detection limit for $\mathrm{P}$ is $5 \mathrm{ppm}$. 


\begin{tabular}{|l|l|l|l|l|l|l|}
\hline Sample & Mo & V & Sb & Ca & As & P \\
\hline 1 & 15.07 & 9.67 & 75.35 & 5252.00 & ND & 1269.37 \\
\hline 2 & 13.22 & ND & 29.61 & 4801.67 & ND & 2117.55 \\
\hline 3 & 14.73 & ND & 8.32 & 5031.00 & ND & 2097.80 \\
\hline 4 & 10.26 & 6.77 & 31.45 & 4580.67 & ND & 2090.40 \\
\hline 5 & 5.37 & 6.66 & ND & 3441.00 & ND & 1262.15 \\
\hline 6 & ND & 5.33 & ND & 1891.67 & ND & 1225.99 \\
\hline 7 & 3.71 & 6.11 & 35.99 & 2220.33 & ND & 1263.16 \\
\hline 8 & 5.99 & 5.34 & 15.95 & 2145.67 & ND & 1235.08 \\
\hline 9 & 5.60 & 4.87 & 39.07 & 2859.67 & ND & 1226.60 \\
\hline
\end{tabular}

$\mathrm{ND}=$ none detect; the detection limit is $5 \mathrm{ppm}$ for all metals except for $\mathrm{P}$. The detection limit for $\mathrm{P}$ is $5 \mathrm{ppm}$.

Table A36. Post soil digests concentrations for Left 5\% TRAPPS ${ }^{\mathrm{TM}}$ lysimeter at 4-8L:5-10H (ppm).

\begin{tabular}{|l|l|l|l|l|l|l|l|}
\hline Sample & $\mathrm{Pb}$ & $\mathrm{Cr}$ & $\mathrm{Cu}$ & $\mathrm{Ni}$ & $\mathrm{Zn}$ & $\mathrm{Fe}$ & $\mathrm{Mn}$ \\
\hline 1 & 113.24 & 27.91 & 75.46 & 17.91 & 10.07 & 14745.00 & 65.45 \\
\hline 2 & 2042.33 & 32.69 & 202.77 & 18.26 & 21.17 & 13035.00 & 73.34 \\
\hline 3 & 2042.33 & 32.69 & 202.77 & 18.26 & 21.17 & 13035.00 & 73.34 \\
\hline 4 & 1921.00 & 12.73 & 288.10 & 5.93 & 25.29 & 3563.00 & 20.70 \\
\hline 5 & 1693.00 & 24.57 & 666.10 & 13.45 & 45.47 & 9347.00 & 49.17 \\
\hline 6 & $\mathrm{ND}$ & 14.31 & 16.71 & 8.23 & 5.73 & 2984.00 & 25.77 \\
\hline 7 & 11220.00 & 25.55 & 617.70 & 12.97 & 101.35 & 3494.33 & 60.84 \\
\hline 8 & 7820.00 & 16.48 & 716.35 & 10.55 & 69.57 & 8498.50 & 48.72 \\
\hline 9 & 591.00 & 7.40 & 85.98 & 6.70 & 9.26 & 2398.00 & 22.91 \\
\hline
\end{tabular}

$\mathrm{ND}=$ none detect; the detection limit is $5 \mathrm{ppm}$ for all metals except for $\mathrm{P}$. The detection limit for $\mathrm{P}$ is $5 \mathrm{ppm}$.

\begin{tabular}{|l|l|l|l|l|l|l|}
\hline Sample & Mo & V & Sb & Ca & As & P \\
\hline 1 & 12.24 & 7.29 & ND & 5009.67 & ND & 2490.33 \\
\hline 2 & 14.50 & 6.49 & 15.32 & 4520.67 & ND & 1908.33 \\
\hline 3 & 14.50 & 6.49 & 15.32 & 3299.67 & ND & 2176.67 \\
\hline 4 & 13.23 & 8.30 & 19.14 & 4752.67 & ND & 1421.54 \\
\hline 5 & 10.86 & ND & 23.67 & 3515.33 & ND & 3085.72 \\
\hline 6 & ND & ND & ND & 2431.67 & ND & 1427.59 \\
\hline 7 & 7.92 & 6.05 & 122.90 & 4171.00 & ND & 2043.87 \\
\hline 8 & 11.96 & ND & 83.70 & 3864.67 & ND & 2242.79 \\
\hline 9 & ND & ND & 7.16 & 3242.33 & ND & 1994.65 \\
\hline
\end{tabular}

$\mathrm{ND}=$ none detect; the detection limit is $5 \mathrm{ppm}$ for all metals except for $\mathrm{P}$. The detection limit for $\mathrm{P}$ is $5 \mathrm{ppm}$. 
Table A37. Post soil digests concentrations for Left 5\% TRAPPS ${ }^{\mathrm{TM}}$ lysimeter at 0-4L:0-5H (ppm).

\begin{tabular}{|l|l|l|l|l|l|l|l|}
\hline Sample & $\mathrm{Pb}$ & $\mathrm{Cr}$ & $\mathrm{Cu}$ & $\mathrm{Ni}$ & $\mathrm{Zn}$ & $\mathrm{Fe}$ & $\mathrm{Mn}$ \\
\hline 1 & 9273 & $\mathrm{ND}$ & 501.7 & $\mathrm{ND}$ & 52.52 & 1913.5 & 9.66 \\
\hline 2 & 5090 & $\mathrm{ND}$ & 525.25 & $\mathrm{ND}$ & 55.85 & 1973 & 9.56 \\
\hline 3 & 1603 & $\mathrm{ND}$ & 347.77 & $\mathrm{ND}$ & 36.47 & 2986.33 & 13.16 \\
\hline 4 & 1586.33 & $\mathrm{ND}$ & 246.67 & $\mathrm{ND}$ & 28.19 & 1964.00 & 9.28 \\
\hline 5 & 5261.67 & 9.20 & 750.50 & 6.52 & 85.25 & 5861.67 & 30.31 \\
\hline 6 & 358.7 & 13.59 & 229.83 & 9.32 & 30.6 & 7372.67 & 41.50 \\
\hline 7 & 4044 & $\mathrm{ND}$ & 540.27 & $\mathrm{ND}$ & 37.65 & 1180 & 6.93 \\
\hline 8 & 2545.67 & 7.06 & 1342.53 & 5.52 & 27.97 & 4309.33 & 22.53 \\
\hline 9 & 2342.33 & 7.99 & 282.90 & 5.54 & 42.51 & 4609.33 & 24.09 \\
\hline
\end{tabular}

$\mathrm{ND}=$ none detect; the detection limit is $5 \mathrm{ppm}$ for all metals except for $\mathrm{P}$. The detection limit for $\mathrm{P}$ is $5 \mathrm{ppm}$.

\begin{tabular}{|l|l|l|l|l|l|l|}
\hline Sample & Mo & V & Sb & Ca & As & P \\
\hline 1 & ND & ND & 114.45 & 934.80 & ND & 2140.67 \\
\hline 2 & ND & ND & 63.11 & 1260.50 & ND & 2379.05 \\
\hline 3 & ND & ND & 17.33 & 1341.67 & ND & 2182.77 \\
\hline 4 & ND & ND & 15.64 & 1261.33 & ND & 2298.12 \\
\hline 5 & ND & ND & 59.37 & ND & ND & 2486.97 \\
\hline 6 & ND & ND & ND & 4779.67 & ND & 2500.04 \\
\hline 7 & ND & ND & 40.65 & 1445.67 & ND & 2249.27 \\
\hline 8 & ND & ND & 22.28 & 3539.67 & ND & 2257.02 \\
\hline 9 & ND & ND & 19.89 & 3372 & ND & 2571.10 \\
\hline
\end{tabular}

$\mathrm{ND}=$ none detect; the detection limit is $5 \mathrm{ppm}$ for all metals except for $\mathrm{P}$. The detection limit for $\mathrm{P}$ is $5 \mathrm{ppm}$.

Table A38. Post soil digests concentrations for Left 5\% TRAPPS ${ }^{\mathrm{TM}}$ lysimeter at 0-4L:5-10H (ppm).

\begin{tabular}{|l|l|l|l|l|l|l|l|}
\hline Sample & $\mathrm{Pb}$ & $\mathrm{Cr}$ & $\mathrm{Cu}$ & $\mathrm{Ni}$ & $\mathrm{Zn}$ & $\mathrm{Fe}$ & $\mathrm{Mn}$ \\
\hline 1 & $\mathrm{NS}$ & $\mathrm{NS}$ & $\mathrm{NS}$ & $\mathrm{NS}$ & $\mathrm{NS}$ & $\mathrm{NS}$ & $\mathrm{NS}$ \\
\hline 2 & $\mathrm{NS}$ & $\mathrm{NS}$ & $\mathrm{NS}$ & $\mathrm{NS}$ & $\mathrm{NS}$ & $\mathrm{NS}$ & NS \\
\hline 3 & 1226.00 & 16.23 & 159.57 & $\mathrm{ND}$ & 22.34 & 9459 & 76.72 \\
\hline 4 & 813.60 & $\mathrm{ND}$ & 146.81 & $\mathrm{ND}$ & 18.18 & 188.30 & ND \\
\hline 5 & 8445.67 & $\mathrm{ND}$ & 452.57 & $\mathrm{ND}$ & 47.43 & 849.37 & ND \\
\hline 6 & 2150.33 & 11.41 & 218.00 & $\mathrm{ND}$ & 28.81 & 4976 & 27.93 \\
\hline 7 & 4947.33 & $\mathrm{ND}$ & 850.10 & ND & 90.07 & 837.60 & ND \\
\hline 8 & 3786.33 & 6.06 & 301.45 & ND & 72.98 & 4705.67 & 21.60 \\
\hline 9 & 2375.67 & 19.73 & 463.10 & ND & 54.01 & 9968.67 & 52.82 \\
\hline
\end{tabular}

$\mathrm{ND}=$ none detect; the detection limit is $5 \mathrm{ppm}$ for all metals except for $\mathrm{P}$. The detection limit for $\mathrm{P}$ is $5 \mathrm{ppm}$. 


\begin{tabular}{|l|l|l|l|l|l|l|}
\hline Sample & Mo & V & Sb & Ca & As & P \\
\hline 1 & NS & NS & NS & NS & NS & NS \\
\hline 2 & NS & NS & NS & NS & NS & NS \\
\hline 3 & 8.41 & ND & 9.17 & 2725.00 & ND & 4201.07 \\
\hline 4 & ND & ND & ND & 502.30 & ND & 2125.47 \\
\hline 5 & ND & ND & 116.33 & 689.33 & ND & 3029.37 \\
\hline 6 & 5.23 & ND & 23.91 & 3056.33 & ND & 3263.16 \\
\hline 7 & ND & ND & 49.13 & 781.27 & ND & 3943.41 \\
\hline 8 & ND & ND & 39.86 & 2202.00 & ND & 3469.34 \\
\hline 9 & 9.41 & ND & 23.26 & 3928.33 & ND & 2704.29 \\
\hline
\end{tabular}

$\mathrm{ND}=$ none detect; the detection limit is $5 \mathrm{ppm}$ for all metals except for $\mathrm{P}$. The detection limit for $\mathrm{P}$ is $5 \mathrm{ppm}$.

Table A39. Post soil digests concentrations for Left 5\% TRAPPS ${ }^{\mathrm{TM}}$ lysimeter at 4-8L:0-5H (ppm).

\begin{tabular}{|l|l|l|l|l|l|l|l|}
\hline Sample & $\mathrm{Pb}$ & $\mathrm{Cr}$ & $\mathrm{Cu}$ & $\mathrm{Ni}$ & $\mathrm{Zn}$ & $\mathrm{Fe}$ & $\mathrm{Mn}$ \\
\hline 1 & $\mathrm{NS}$ & NS & NS & NS & NS & NS & NS \\
\hline 2 & NS & NS & NS & NS & NS & NS & NS \\
\hline 3 & NS & NS & NS & NS & NS & NS & NS \\
\hline 4 & NS & NS & NS & NS & NS & NS & NS \\
\hline 5 & NS & NS & NS & NS & NS & NS & NS \\
\hline 6 & NS & NS & NS & NS & NS & NS & NS \\
\hline 7 & NS & NS & NS & NS & NS & NS & NS \\
\hline 8 & 3304 & 12.84 & 221.40 & ND & 28.56 & 7617.33 & 39.32 \\
\hline 9 & 744.77 & 6.53 & 74.28 & ND & 11.57 & 4212.00 & 18.81 \\
\hline
\end{tabular}

$\mathrm{ND}=$ none detect; the detection limit is $5 \mathrm{ppm}$ for all metals except for $\mathrm{P}$. The detection limit for $\mathrm{P}$ is $5 \mathrm{ppm}$.

\begin{tabular}{|l|l|l|l|l|l|l|}
\hline Sample & Mo & V & Sb & Ca & As & P \\
\hline 1 & NS & NS & NS & NS & NS & NS \\
\hline 2 & NS & NS & NS & NS & NS & NS \\
\hline 3 & NS & NS & NS & NS & NS & NS \\
\hline 4 & NS & NS & NS & NS & NS & NS \\
\hline 5 & NS & NS & NS & NS & NS & NS \\
\hline 6 & NS & NS & NS & NS & NS & NS \\
\hline 7 & NS & NS & NS & NS & NS & NS \\
\hline 8 & ND & ND & ND & 4212.33 & ND & 2184.37 \\
\hline 9 & ND & ND & ND & 2384.00 & ND & 2065.89 \\
\hline
\end{tabular}

$\mathrm{ND}=$ none detect; the detection limit is $5 \mathrm{ppm}$ for all metals except for $\mathrm{P}$. The detection limit for $\mathrm{P}$ is $5 \mathrm{ppm}$. 
Table A40. Post soil digests concentrations for Left 5\% TRAPPS ${ }^{\mathrm{TM}}$ lysimeter at 4-8L:5-10H (ppm).

\begin{tabular}{|l|l|l|l|l|l|l|l|}
\hline Sample & $\mathrm{Pb}$ & $\mathrm{Cr}$ & $\mathrm{Cu}$ & $\mathrm{Ni}$ & $\mathrm{Zn}$ & $\mathrm{Fe}$ & $\mathrm{Mn}$ \\
\hline 1 & 6822.67 & 9.31 & 623.53 & $\mathrm{ND}$ & 68.87 & 5314.00 & 28.85 \\
\hline 2 & 1763.50 & 7.71 & 162.90 & $\mathrm{ND}$ & 21.79 & 3289.67 & 18.11 \\
\hline 3 & 3030.33 & $\mathrm{ND}$ & 302.77 & $\mathrm{ND}$ & 34.34 & 937.53 & 6.03 \\
\hline 4 & 4728.67 & 6.00 & 423.37 & $\mathrm{ND}$ & 41.71 & 2765.67 & 15.25 \\
\hline 5 & 3710.33 & $\mathrm{ND}$ & 475.63 & $\mathrm{ND}$ & 53.68 & 1206.33 & 7.48 \\
\hline 6 & 6368.00 & $\mathrm{ND}$ & 692.95 & $\mathrm{ND}$ & 76.43 & 1934.00 & 12.25 \\
\hline 7 & 5866.33 & $\mathrm{ND}$ & 784.83 & $\mathrm{ND}$ & 85.75 & 1189.50 & 6.89 \\
\hline 8 & 6950.00 & $\mathrm{ND}$ & 505.17 & $\mathrm{ND}$ & 58.44 & 804.57 & 5.21 \\
\hline 9 & $\mathrm{NS}$ & $\mathrm{NS}$ & $\mathrm{NS}$ & $\mathrm{NS}$ & $\mathrm{NS}$ & $\mathrm{NS}$ & $\mathrm{NS}$ \\
\hline
\end{tabular}

$\mathrm{ND}=$ none detect; the detection limit is $5 \mathrm{ppm}$ for all metals except for $\mathrm{P}$. The detection limit for $\mathrm{P}$ is $5 \mathrm{ppm}$.

\begin{tabular}{|l|l|l|l|l|l|l|}
\hline Sample & Mo & V & Sb & Ca & As & P \\
\hline 1 & ND & ND & 76.12 & 3587.00 & ND & 2912.80 \\
\hline 2 & ND & ND & 16.65 & 2473.00 & ND & 2872.07 \\
\hline 3 & ND & ND & 29.76 & 1084.67 & ND & 2477.15 \\
\hline 4 & ND & ND & 50.40 & 1763.67 & ND & 3307.66 \\
\hline 5 & ND & ND & 38.33 & 1392.33 & ND & 2444.83 \\
\hline 6 & ND & ND & 67.81 & 1748.67 & ND & 2946.74 \\
\hline 7 & ND & ND & 64.51 & 1622.33 & ND & 2604.93 \\
\hline 8 & ND & ND & 82.33 & 1212.00 & ND & 3305.33 \\
\hline 9 & NS & NS & NS & NS & NS & NS \\
\hline
\end{tabular}

$\mathrm{ND}=$ none detect; the detection limit is $5 \mathrm{ppm}$ for all metals except for $\mathrm{P}$. The detection limit for $\mathrm{P}$ is $5 \mathrm{ppm}$.

\section{Soil Partition Coeficient Determination $\left(K_{d}\right)$}

Table A41 Linear $\mathrm{K}_{d}$ Data: Triplicate data for each lysimeter for Sb(III).

\begin{tabular}{|l|l|l|l|}
\hline $\begin{array}{l}\text { Sb III Initial conc. } \\
(\mathrm{ppm})\end{array}$ & $\begin{array}{l}\text { Control } \\
\text { Sb III Final conc. (ppm) }\end{array}$ & $\begin{array}{l}7.62 \mathrm{~mm} \\
\text { Sb III Final conc. }(\mathrm{ppm})\end{array}$ & $\begin{array}{l}\text { 5\% TRAPPS } \\
\text { Sb III Final conc. (ppm) }\end{array}$ \\
\hline $0.95-1$ & 0.5263 & 0.5411 & 0.3506 \\
\hline $0.95-2$ & 0.5826 & 0.3485 & 0.1225 \\
\hline $0.95-3$ & 0.5825 & 0.3451 & 0.0896 \\
\hline $8.80-1$ & 7.466 & 4.143 & 1.351 \\
\hline $8.80-2$ & 7.76 & 5.133 & 1.075 \\
\hline $8.80-3$ & 7.835 & 4.097 & N/A \\
\hline $23.40-1$ & 20.87 & 14.96 & 6.207 \\
\hline $23.40-2$ & 20.45 & N/A & 7.528 \\
\hline $23.40-3$ & 21.34 & 15.15 & 7.607 \\
\hline $47.36-1$ & 43.2 & 23.57 & 16.27 \\
\hline
\end{tabular}




\begin{tabular}{|l|l|l|l|}
\hline $\begin{array}{l}\text { Sb III Initial conc. } \\
(\mathrm{ppm})\end{array}$ & $\begin{array}{l}\text { Control } \\
\text { Sb III Final conc. (ppm) }\end{array}$ & $\begin{array}{l}7.62 \mathrm{~mm} \\
\text { Sb III Final conc. }(\mathrm{ppm})\end{array}$ & $\begin{array}{l}5 \% \text { TRAPPS } \\
\text { Sb III Final conc. }(\mathrm{ppm})\end{array}$ \\
\hline $47.36-2$ & 43.6 & 26.90 & 22.57 \\
\hline $47.36-3$ & 44.35 & 22.12 & 13.16 \\
\hline $95.66-1$ & 90.81 & 43.48 & 50.44 \\
\hline $95.66-2$ & 90.51 & 53.53 & 50.06 \\
\hline $95.66-3$ & 92.15 & 44.55 & 43.28 \\
\hline
\end{tabular}

Table A42. Linear $\mathrm{K}_{d}$ Data: Triplicate data for each lysimeter for $\mathrm{Sb}(\mathrm{V})$.

\begin{tabular}{|l|l|l|l|}
\hline $\begin{array}{l}\text { Sb V Initial conc. } \\
(\mathrm{ppm})\end{array}$ & $\begin{array}{l}\text { Control } \\
\text { Sb V Final conc. }(\mathrm{ppm})\end{array}$ & $\begin{array}{l}7.62 \mathrm{~mm} \\
\text { Sb V Final conc. }(\mathrm{ppm})\end{array}$ & $\begin{array}{l}\text { 5\% TRAPPSTM + 5\% TTF } \\
\text { Sb V Final conc. }(\mathrm{ppm})\end{array}$ \\
\hline $0.87-1$ & N/A & N/A & 0.8367 \\
\hline $0.87-2$ & 0.9793 & 0.8576 & 0.8466 \\
\hline $0.87-3$ & 0.9512 & N/A & 0.8075 \\
\hline $9.06-1$ & 8.999 & 8.628 & 8.197 \\
\hline $9.06-2$ & N/A & 8.751 & 8.303 \\
\hline $9.06-3$ & 9.006 & 8.582 & 1.361 \\
\hline $23.14-1$ & 22.75 & 21.87 & 20.94 \\
\hline $23.14-2$ & 22.65 & 22.11 & 19.22 \\
\hline $23.14-3$ & 23.07 & 22.46 & 19.90 \\
\hline $47.92-1$ & 45.46 & 45.64 & 40.62 \\
\hline $47.92-2$ & 46.62 & 44.42 & 40.71 \\
\hline $47.92-3$ & 45.38 & 45.21 & 41.12 \\
\hline $101.1-1$ & 89.92 & 94.16 & 83.41 \\
\hline $101.1-2$ & 90.92 & 92.45 & 83.79 \\
\hline $101.1-3$ & 91.03 & 91.92 & 82.45 \\
\hline
\end{tabular}




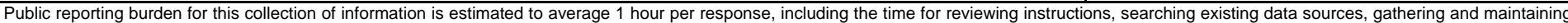

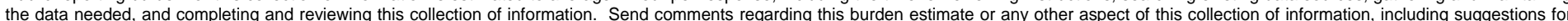

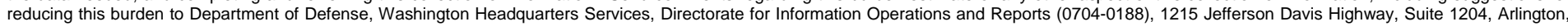

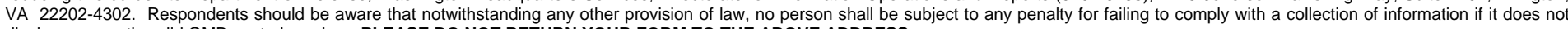
display a currently valid OMB control number. PLEASE DO NOT RETURN YOUR FORM TO THE ABOVE ADDRESS.
1. REPORT DATE (DD-MM-YYYY) 2. REPORT TYPE Final
3. DATES COVERED (From - To)

August 2012

\section{TITLE AND SUBTITLE}

Passive Reactive Berm to Provide Low Maintenance Lead Containment at Active Small Arms Firing Ranges: Field Demonstration

5a. CONTRACT NUMBER

5b. GRANT NUMBER

5c. PROGRAM ELEMENT NUMBER

\section{AUTHOR(S)}

Michelle Wynter, Steven L. Larson, W.A. Martin, Chris S. Griggs, Gregory O’Connor, David Mackie, and Catherine C. Nestler

5d. PROJECT NUMBER

5e. TASK NUMBER

5f. WORK UNIT NUMBER

\section{PERFORMING ORGANIZATION NAME(S) AND ADDRESS(ES)}

8. PERFORMING ORGANIZATION REPORT

(see reverse) NUMBER

ERDC/EL TR-12-20

\section{SPONSORING I MONITORING AGENCY NAME(S) AND ADDRESS(ES)}

Washington, DC 20314-1000

11. SPONSOR/MONITOR'S REPORT NUMBER(S)

\section{DISTRIBUTION I AVAILABILITY STATEMENT}

Approved for public release; distribution is unlimited.

\section{SUPPLEMENTARY NOTES}

\section{ABSTRACT}

Heavy metals are released into the environment as a result of critical military live-fire training. Preventing heavy-metal migration into and contamination of the local environment is crucial because remediating contaminated soils is resource intensive, difficult, and costly. Previous studies have demonstrated that phosphate amendments have been successfully used as a best management practice (BMP) to immobilize metal contaminants. The Passive Reactive Berm (PRBerm ${ }^{\mathrm{TM}}$ ) technology incorporates phosphate amendments with ballistic sand to immobilize soluble metals (e.g., lead) during the inevitable bullet corrosion process. Treatability studies determined that an amendment ratio of $5 \%$ (weight/weight) to sand was sufficient to contain $>90 \%$ of soluble lead within the berm material. The technology was field tested on the M-60 small arms firing range (SAFR) at Charleston Air Force Base (CAFB) in Charleston, South Carolina. The CAFB PRBerm ${ }^{\mathrm{TM}}$ was tested with a 5\% TRAPPS ${ }^{\mathrm{TM}}$ amendment (a granular, apatite-based material), alone and in combination with a 5\% thermally treated fish bone Apatite ${ }^{\mathrm{TM}}$.

For the CAFB PRBerm ${ }^{\mathrm{TM}}$, storm water runoff and leachate water samples were collected directly from the SAFR and analyzed for metals, total suspended solids (TSS), and pH. Reduced metals migration in soil leachate and surface water runoff when compared to the traditional earthen berm was observed. The total suspended solids in the leachate and runoff waters from the amended berms increased over the control berm. Results indicated that the $\mathrm{pH}$ of the runoff waters from the amended berms remained acidic.

The benefits of the PRBerm ${ }^{\mathrm{TM}}$ when compared to the traditional earthen berm, or a fully contained bullet trap, include reduced metals migration in soil leachate and surface water runoff, as well as reduced construction and operation costs. The PRBerm ${ }^{\mathrm{TM}}$ has the potential to provide a useful, low-cost tool for defense forces to maintain active firing ranges while managing the inevitable effects of small arms residue corrosion in a low-cost and effective manner.

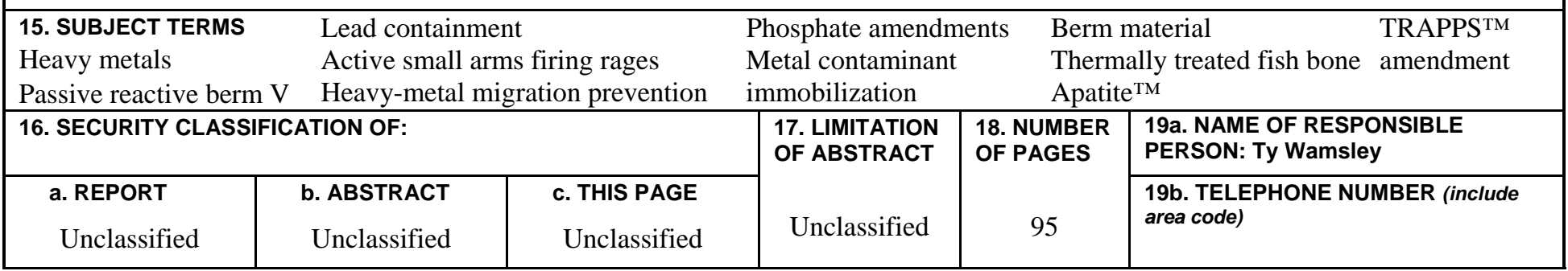




\section{PERFORMING ORGANIZATION NAME(S) AND ADDRESS(ES) (concluded)}

Environmental Laboratory

U.S. Army Engineer Research and Development Center 3909 Halls Ferry Road

Vicksburg, MS 39180-6199

U.S. Army RDECOM-ARDEC

Energetics, Warheads, \& Environmental Technology Research Division Building 355

Picatinny, NJ 07806-5000

AMEC Earth and Environmental, Inc.

285 Davidson Avenue, Suite 100

Somerset, NJ 08873

Applied Research Associates

119 Monument Place

Vicksburg, MS 39180 